\title{
Review
}

\section{Lichen algae: the photosynthetic partners in lichen symbioses}

\author{
William B. Sanders ${ }^{1}$ (D) and Hiroshi Masumoto ${ }^{2}$ \\ ${ }^{1}$ Department of Biological Sciences, Florida Gulf Coast University, Ft. Myers, FL 33965-6565, USA and ${ }^{2}$ Laboratory of Terrestrial Microbiology and Systematics, \\ Graduate School of Global Environmental Studies, Kyoto University, Yoshida-Honmachi, Sakyo-ku, Kyoto 606-8501, Japan
}

\begin{abstract}
A review of algal (including cyanobacterial) symbionts associated with lichen-forming fungi is presented. General aspects of their biology relevant to lichen symbioses are summarized. The genera of algae currently believed to include lichen symbionts are outlined; approximately 50 can be recognized at present. References reporting algal taxa in lichen symbiosis are tabulated, with emphasis on those published since the 1988 review by Tschermak-Woess, and particularly those providing molecular evidence for their identifications. This review is dedicated in honour of Austrian phycologist Elisabeth Tschermak-Woess (1917-2001), for her numerous and significant contributions to our knowledge of lichen algae (some published under the names Elisabeth Tschermak and Liesl Tschermak).
\end{abstract}

Key words: chlorobiont, cyanobacteria, cyanobiont, lichenized stramenopiles, phaeobiont, photobiont, phycobiont, xanthobiont

(Accepted 17 June 2021)

\section{Introduction}

The principal components of the lichen symbiosis are fungus and alga. Their intimate trophic relationship remains central to the lichen concept, despite our growing appreciation that other microorganisms harboured within the thallus might also play significant roles (Lakatos et al. 2004; Grube \& Berg 2009; Bates et al. 2011; Grube et al. 2015; Spribille et al. 2016; Muggia \& Grube 2018; Mark et al. 2020; Smith et al. 2020; Tzovaras et al. 2020). The lichenforming fungi typically build distinctive vegetative tissues and characteristic sexual structures, providing numerous biological features for study and significant clues about phylogenetic relationships, which are now relatively well delimited at broader taxonomic levels (Jaklitsch et al. 2016; Lücking et al. 2017a). Lichen algae, by contrast, have proved much more elusive. Most are unicells or simple filaments, with sexual structures unknown or seldom reported. The paucity of phenotypic characters is often aggravated by their plasticity. Lichen algae may look and behave quite differently in symbiosis with different lichen-forming fungi, in the free-living condition in nature and in aposymbiotic laboratory culture (Fig. 1; Ahmadjian 1967; Bubrick 1988). All this has hindered progress in clarifying their identities, phylogenies and life histories. Schwendener (1869) was the first to survey lichen 'gonidia' in a phycological context, recognizing them as organisms distinct from the surrounding fungus that correspond to known taxa of freeliving algae. In the last half-century, the diversity of lichen-forming algae has been reviewed by various authors (Ahmadjian 1967; Létrouit-Galinou 1968; Henssen \& Jahns 1974; Friedl \& Büdel 2008), with a particularly thorough literature summary compiled and annotated by Tschermak-Woess (1988a).

Author for correspondence: William B. Sanders. E-mail: wsanders@fgcu.edu

Cite this article: Sanders WB and Masumoto H (2021) Lichen algae: the photosynthetic partners in lichen symbioses. Lichenologist 53, 347-393. https://doi.org/10.1017/ S0024282921000335
In recent decades, our understanding of algal diversity and biosystematics has advanced substantially with the accumulation, analysis and integration of DNA sequence data. Systematic schemes for the eukaryotic algae have changed considerably, as the broad contours of consensus emerge concerning phylogenies and their reconstruction. Recent works have reviewed the current status of some principal algal groups with lichen-forming taxa, such as the genus Trebouxia (Muggia et al. 2017), the class Trebouxiophyceae (Muggia et al. 2018), the Coccomyxa-Elliptochloris clade (Gustavs et al. 2017), the Trentepohliaceae (Grube et al. 2017a), and the cyanobacteria (Rikkinen 2017). Yet most taxa remain insufficiently understood. Even the most intensively studied genera, such as Trebouxia, are still unresolved with respect to species delimitation, and much new diversity continues to be uncovered (Muggia et al.2020). A great many algal symbionts, identified phenotypically (often without isolation into culture) or recorded merely as 'trebouxioid' or 'chlorococcalean', have yet to be revisited with DNA sequence analyses. Identities and relationships remain especially problematic among the cyanobacteria (bluegreen algae), where sexual reproduction is absent, diversification is ancient (Garcia-Pichel 2009) and horizontal gene transfer events may obscure the vertical components of phylogenies (Zhaxybayeva et al. 2006). The aposymbiotic lives of lichen algae also remain largely unknown, despite their potential importance in active genetic mixing. Here an attempt is made to focus more attention on the algal side of the lichen partnership, still relatively neglected compared to that of the fungus. We include a synopsis of the relevant genera and list citations of algal taxa in lichen symbiosis (Table 1), emphasizing those published since Tschermak-Woess's (1988a) landmark review, and particularly those accompanied by genetic sequence data.

\section{The Major Algal Groups Involved}

Lichen algae are diverse. This may contribute to the distinct distributions and climatic preferences of the symbiotic thalli that 


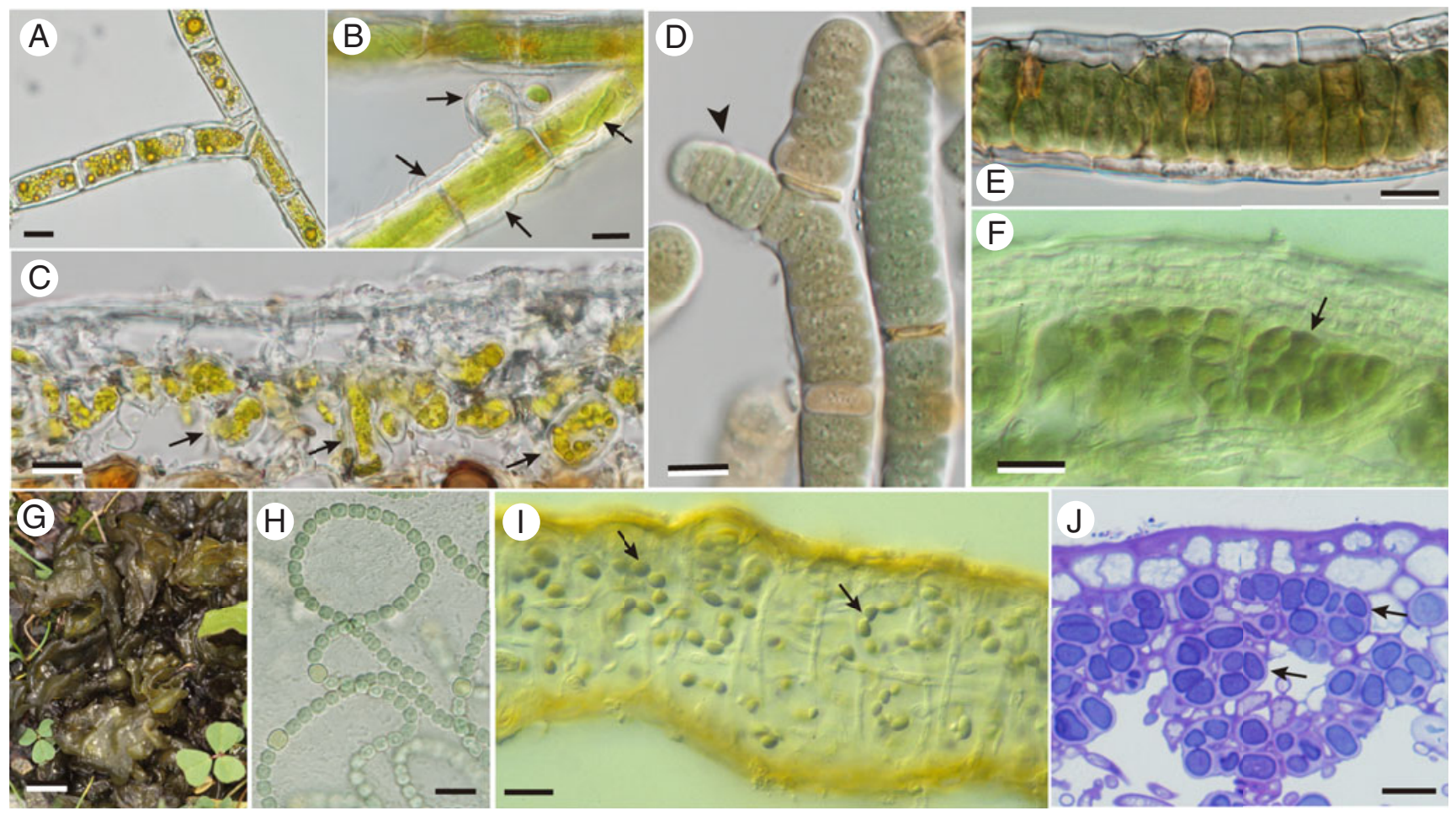

Fig. 1. Three filamentous lichen photobiont genera in aposymbiotic and symbiotic states. A-C, Trentepohlia. A, branching filament free-living on bark. B, lichenized by Coenogonium hyphae (arrows) growing over morphologically unchanged algal filament and its new branches (horizontal arrow). C, lichenized by Arthonia rubrocincta; the alga is largely broken up into individual cells or short segments. D-F, Rhizonema. D, cultured isolate from Dictyonema; note false branching (arrowhead). E, trichome ensheathed by cells of mycobiont Dictyonema. F, contorted or broken filaments (arrow) within thallus of Coccocarpia palmicola. G-J. Nostoc. G, freeliving thallus-like macrocolony on soil. $\mathrm{H}$, cultured strain. I, more or less intact filaments (arrows) within thallus of Collema furfuraceum. J, contorted or broken up into cell groups (arrows) within cyanomorph of Sticta canariensis. Scales: A-F, $\mathrm{H}-\mathrm{J}=10 \mu \mathrm{m} ; \mathrm{G}=1 \mathrm{~cm}$.

enclose them (Marini et al. 2011). Most are green algae, a paraphyletic grouping of two major clades: the charophytes (Streptophyta), from which embryophytes descend, and the Chlorophyta s. str. (Leliaert et al. 2012). The latter includes nearly all green algae reported as lichen symbionts. Within the Chlorophyta, lichen symbionts are found principally in the classes Trebouxiophyceae and Ulvophyceae. A third class, the Chlorophyceae, is known or suspected to include the partners of several lichens. The prokaryotic blue-green algae (cyanobacteria) encompass most of the remainder, occurring in c. $10 \%$ of the nearly 20000 known lichen associations (Rikkinen 2017). Additionally, two stramenopile algae (a xanthophyte and a phaeophyte) are known to enter into lichen symbioses. The full range of phylogenetic disparity among lichen-forming algae is therefore much wider than that found among the lichen-forming fungi, which all fall within the kingdom's Dikarya crown group (mostly Ascomycota, with several genera of Basidiomycota). Just what common features might permit those disparate algal lineages to form comparable symbioses with lichen-forming fungi remain enigmatic. As colonizers of exposed, subaerial substrata, potentially suitable algae may be pre-adapted to coping with hydric stresses and high radiation loads (Lange et al. 1990; Gustavs et al. 2010; Candotto Carniel et al. 2015). It is striking that most lineages of basidiomycete fungi that independently adopted the lichen lifestyle did not domesticate novel algal genera; instead they chose taxa that associate with ascolichens, such as Coccomyxa, Elliptochloris and Rhizonema (Oberwinkler 2012; Dal Forno et al. 2020; Masumoto 2020; but see Hodkinson et al. (2014) concerning Lepidostromatales). It is also noteworthy that quite a number of lichen algae belong to genera (e.g. Chlorella s. str., Coccomyxa, Elliptochloris and Nostoc) that include species occurring in symbiosis (often endosymbioses) with diverse protists, plants and animals (Adams et al. 2012; Grube et al. 2017b).

Algal partners in lichen symbioses were termed phycobionts by Scott (1957). Subsequently, Ahmadjian (1982) proposed that photobiont replace phycobiont where cyanobacteria are meant to be included, because they 'are not algae per se but actually bacteria'. No further argumentation was provided; it was presumed self-evident that algae and bacteria must denote mutually exclusive concepts. Some contemporary treatments distinguish cyanobacteria from algae (e.g. Friedl \& Büdel 2008; Grube et al. 2017b), while others consider them as algae (e.g. Graham et al. 2009; Büdel \& Kauff 2012; Lee 2018). Clearly, there are significant differences between prokaryotes and eukaryotes. At issue, however, is whether those differences are relevant to the concept of algae. This term has no biosystematic status and cannot attain any by exclusion of the blue-greens. The emblematic algal trait, oxygen-generating photosynthesis, is ultimately derived from cyanobacteria. It was subsequently acquired in multiple events involving primary, secondary and tertiary endosymbioses (Keeling 2004, 2013), and now characterizes diverse lineages included within most of the major eukaryote clades (Archaeplastida, Alveolata, Excavata, Rhizaria, Stramenopila, Cryptista and Haptista). The one and only unifying thread in this polyphyletic algal tapestry (Delwiche 1999) is the common photosynthetic apparatus, originating in cyanobacteria and passed on vertically as well as horizontally. The present work therefore uses the term algae to encompass all non-embryophyte lineages that inherited oxygenic photosynthesis. Phycobiont and photobiont are considered synonymous terms. 


\section{The Algal Role in Lichen Symbiosis}

The algal partner is the primary producer, sustaining the lichen association by supplying the fungal partner with carbohydrate products of photosynthesis (Smith 1974). Those with pyrenoids (Fig. 2) possess $\mathrm{CO}_{2}$-concentrating mechanisms that improve the efficiency of carbon fixation (Smith \& Griffiths 1996). Green algal symbionts (chlorobionts) transfer their photosynthate as polyol sugar alcohols such as ribitol (Richardson et al. 1968). Significantly, these compounds also confer desiccation tolerance by providing osmolarity and protecting cell membranes from damage as water is lost (Smith 2019). Polyols are likewise produced by non-symbiotic, aeroterrestrial green algae, particularly under osmotic stress conditions (Darienko et al. 2010; Gustavs et al. 2010, 2011). Blue-green symbionts (cyanobionts) transfer glucose, or glucan, which their fungal partners take up and immediately convert into the sugar alcohol mannitol (Smith \& Drew 1965; Hill 1972). When lichenized, the algal symbionts are somehow induced to leak large amounts of carbohydrate to the surrounding fungal cells, a process that quickly ceases when the algae are isolated into culture (Drew \& Smith 1967). Fungal penetration of photobionts may occur to varying degrees (Geitler 1934; Tschermak 1941a; Plessl 1963; Galun et al. 1970, 1971; Honegger 1986; Matthews et al. 1989), but these so-called haustoria do not appear to be principal conduits of carbohydrate transfer in ascolichens (Jacobs \& Ahmadjian 1971; Collins \& Farrar 1978; Hessler \& Peveling 1978). The intrusive hyphae of certain basidiolichens that deeply penetrate longitudinally through the centre of their cyanobiont trichomes (Roskin 1970; Oberwinkler 1980, 2012) have not yet been examined with respect to substance transfer. In most foliose and fruticose lichens examined, haustorial penetrations are either absent altogether or do not fully traverse the algal cell wall. To facilitate transfer, the mycobiont secretes a hydrophobic sealant that envelops the cell surfaces of both symbionts at their contact zones, thereby funnelling carbohydrate released by the alga to the fungus (Honegger 1991; Trembley et al. 2002a). At least that is the case in the selection of taxa examined so far. Where cyanobacterial symbionts are involved, they provide the lichen fungus with fixed nitrogen as well as carbon (Millbank \& Kershaw 1974). In those lichens (chiefly Peltigerales) where a chlorobiont constitutes the main algal layer and cyanobionts are localized within nodules known as cephalodia, the cyanobacteria become highly specialized for nitrogen fixation, with an elevated percentage of cells differentiating as heterocytes (Hitch \& Millbank 1975). In lichens with only cyanobacterial photobionts, heterocyte frequency can be much lower at the growing margins of the thallus (Bergman \& Hällbom 1981), where photosynthate may be in higher demand.

Whether any substance is transferred from fungus to alga in exchange has yet to be demonstrated. At least some genes relevant to such metabolic transfers appear to be differentially expressed in symbiosis (Kono et al. 2020). Certainly, there has been speculation that the fungal partner might apportion carbohydrate, nitrogen, or other substances back to the algal symbiont to regulate its growth (Ahmadjian 1995) in coordination with that of the mycobiont (Greenhalgh \& Anglesea 1979; Hill 1985, 1989; Honegger 1987). The heterotrophic tendencies shown by many lichen algae (Trebouxia, Asterochloris, Elliptochloris, Coccomyxa, Apatococcus) when cultured in the laboratory (Ahmadjian 1993; Gustavs et al. 2016, 2017) suggest the possibility that they could be susceptible to such control. Indeed, Ahmadjian (2001) proposed that Trebouxia is fully dependent upon its mycobiont for nutrition and is therefore unable to survive in the free-living state (Ahmadjian 1988).
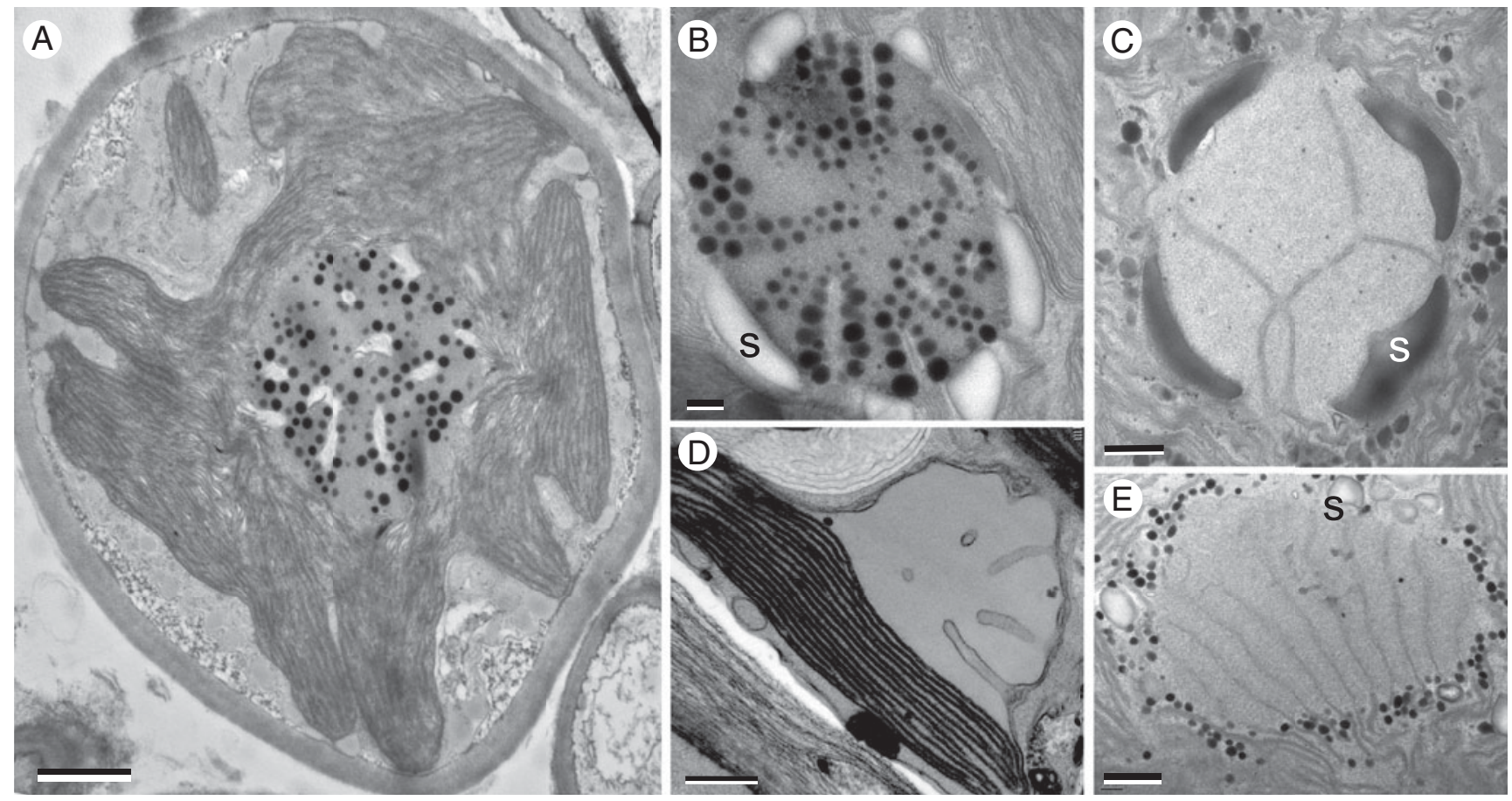

Fig. 2. TEM micrographs of some photobiont pyrenoids, with plastoglobuli (round black dots) and penetrating membranes in various positions and orientations. A, Trebouxia, within thallus of Lasallia pustulata. Note pyrenoid structure here more closely resembles that of distantly related Heveochlorella (B) than that of another species (C) of Trebouxia. B, Heveochlorella, within thallus of Calopadia. C, Trebouxia, within thallus of Ramalina usnea. D, bulging exserted pyrenoid of Petroderma maculiforme. E, Diplosphaera, within thallus of Endocarpon pusillum. S starch grain or plates. Scales: A=1 $\mu \mathrm{m} ; \mathrm{B}=200 \mathrm{~nm} ; \mathrm{C}-\mathrm{E}=500 \mathrm{~nm}$. 
However, he also promoted the seemingly contradictory viewpoint that Trebouxia is a victim of fungal parasitism rather than a mutualist partner (Ahmadjian 1993, 1995, 2002). This would make Trebouxia a host that cannot survive without its parasite.

In any event, proof of fungus-to-alga nutrient transfer is not required to make the case that lichen symbiosis offers advantages to the algal partner. There is considerable evidence that the surrounding fungal tissues and their secondary metabolites may help protect the lichenized alga from desiccation, photoinhibition, temperature extremes and herbivory (e.g. Solhaug \& Gauslaa 1996; Kranner et al. 2008; Kosugi et al. 2009; Asplund \& Wardle 2013; Gauslaa et al. 2017; Míguez et al. 2017; Sadowsky \& Ott 2016; Beckett et al. 2019; Fernández-Marín et al. 2019). Symbiosis may significantly improve the alga's ability to avoid cellular damage caused by highly reactive forms of oxygen (ROS) generated under stress conditions (Kranner et al. 2005). With these protections, and the facilitated display for light capture afforded by a supportive mycobiont structure, lichen algae may greatly expand their ecological range and abundance via symbiosis (Honegger 2012). On the other hand, lichen symbioses are diverse and it is likely that the parameters of the relationship vary among taxa, along environmental gradients, and perhaps also during the course of a single lichen's development. The long history of attempts to maintain or resynthesize lichens in the laboratory has provided a key insight into the nature of this seemingly wellintegrated association: it is very much a relationship of contingency. That the partners can often be cultured separately on appropriate media in the laboratory (Ahmadjian 1993; Crittenden et al. 1995; Stocker-Wörgötter \& Hager 2008) shows there is no strict physiological impediment to growth without symbiosis. To initiate and support lichen formation, a fluctuating balance of conditions suboptimal for separate fungal or algal growth appears to be necessary. Any combination of culture conditions (light, moisture, nutrient availability) that continuously favours either fungal or algal growth results in the breakdown of symbiotic structures, and the dissociated proliferation of the micro-organisms separately (Thomas 1939; Scott 1960; Ahmadjian 1962; Stocker-Wörgötter 2001; but see Marton \& Galun 1976). It therefore seems logical to view the lichen symbiosis as a more or less mutualistic response to conditions that permit neither partner to thrive independently.

Although both partners may derive benefits, the lichen symbiosis is clearly not symmetrical (Hill 2009). The heterotrophic mycobionts, with their elaborate structural adaptations for algal cultivation, are more fully committed to symbiosis than their trophically autonomous photobionts. The mycobiont frees itself of symbiosis only in spore dispersal, seeking algal partners again immediately upon germination. To carry out sexual reproduction, it must be in symbiosis, whereas its photobiont appears to need aposymbiotic freedom to do so. From the alga's point of view, whenever unfavourable conditions reduce its possibilities of aposymbiotic success, the benefits of lichenization may begin to outweigh any disadvantages. Photobionts may rely on lichen symbioses for longterm persistence in habitats periodically subject to adverse conditions, while needing intervals of independence under favourable conditions to complete their life cycles. Thus, mycobiont and photobiont life histories do not fully coincide, but produce a lichen where they intersect compatibly. To varying degrees, natural selection has optimized the mycobiont principally for symbiosis, the photobiont for autonomy as well as symbiosis. The trade-off is that greater adaptation to symbiotic compatibility is likely to constrain the possibilities for competitive success in the aposymbiotic state. However, the lingering notion that certain photobionts may not ever occur free-living is probably attributable to insufficient sampling, and the conflation of invisibility with absence. Unsurprisingly, those photobionts that are macroscopically visible (Nostoc, Cephaleuros, Phycopeltis, Trentepohlia, Prasiola, Petroderma) have not had their aposymbiotic occurrence disputed.

Both fungus and alga must adapt, at least to some extent, to be compatible symbionts. For some authors, such mutual adaptation constitutes coevolution (Ahmadjian 1987; Saini et al. 2019); for others, coevolution supposes parallel cladogenesis in partners' phylogenies, a criterion not generally met by lichen symbioses analyzed in this regard (Piercey-Normore \& DePriest 2001; Stenroos et al. 2006). However, it has been argued that focusing exclusively on this fine scale ignores broader patterns of co-adaptation, whereby 'guilds' of different mycobionts share common pools of photobionts to mutual advantage (Rikkinen 2003, 2013). According to Hill (2009), photobionts cannot coevolve with their mycobionts because they lack sexual reproduction in the thallus, are not subject to natural selection from one lichen to the next, and are not perpetuated when a lichen thallus dies. Yet photobionts are continually escaping from lichen thalli by means of soredia, isidia, thallus fragments, co-dispersed hymenial, epithecial or conidiomal algae (Fig. 3), and the excreta of lichenivorous invertebrates (Fröberg et al. 2001; Meier et al. 2002; Boch et al. 2011). Such diaspores afford many chances of finding microconditions where independent algal growth is favoured; aposymbiotic, potentially sexual populations may then develop, be they brief or enduring. Selection among genotypes for compatibility (or resistance) will occur when the opportunity for relichenization next presents itself. Compatible genotypes incorporated into a developing lichen may then be subject to further winnowing selection in the course of thallus growth.

\section{Patterns of Symbiont Pairing}

The asymmetrical needs of the lichen symbionts are reflected in the non-reciprocal patterns of pairing that have evolved between mycobionts and photobionts. Photobiont genera frequently associate with multiple, phylogenetically disparate lineages of lichen-forming fungi. The converse, however, is much less common; mycobiont genera, and often families and even orders, generally tend to lichenize a single algal genus (Rambold et al. 1998; Peršoh et al. 2004). There are a number of notable exceptions. Lichen-forming fungi of the family Verrucariaceae partner with an extremely diverse array of eukaryotic algae, including the only reported cases of stramenopile phycobionts (Thüs et al. 2011). The pinlichen genus Chaenotheca (Coniocybomycetes) includes species associating with Trebouxia, Trentepohlia, Symbiochloris or Tritostichococcus (Tibell 2001; Škaloud et al. 2016; Pröschold \& Darienko 2020). The fruticose lichen genus Stereocaulon may harbour thallus photobionts of either Asterochloris, Vulcanochloris or Chloroidium (Vančurová et al. 2018). Species of Sticta may partner with chlorobionts of Symbiochloris, Coccomyxa, Elliptochloris, Heveochlorella or Chloroidium (Lindgren et al. 2020). Squamulose Psora decipiens is reported to partner with either Asterochloris, Trebouxia, Chloroidium (Ruprecht et al. 2014) or Myrmecia photobionts (Williams et al. 2017; Moya et al. 2018). In addition, it is well known that many individual mycobionts, particularly in the Peltigerales, may associate with both green and blue-green algae simultaneously, giving rise to cyanobacterial cephalodia within or upon a chlorophyte- 

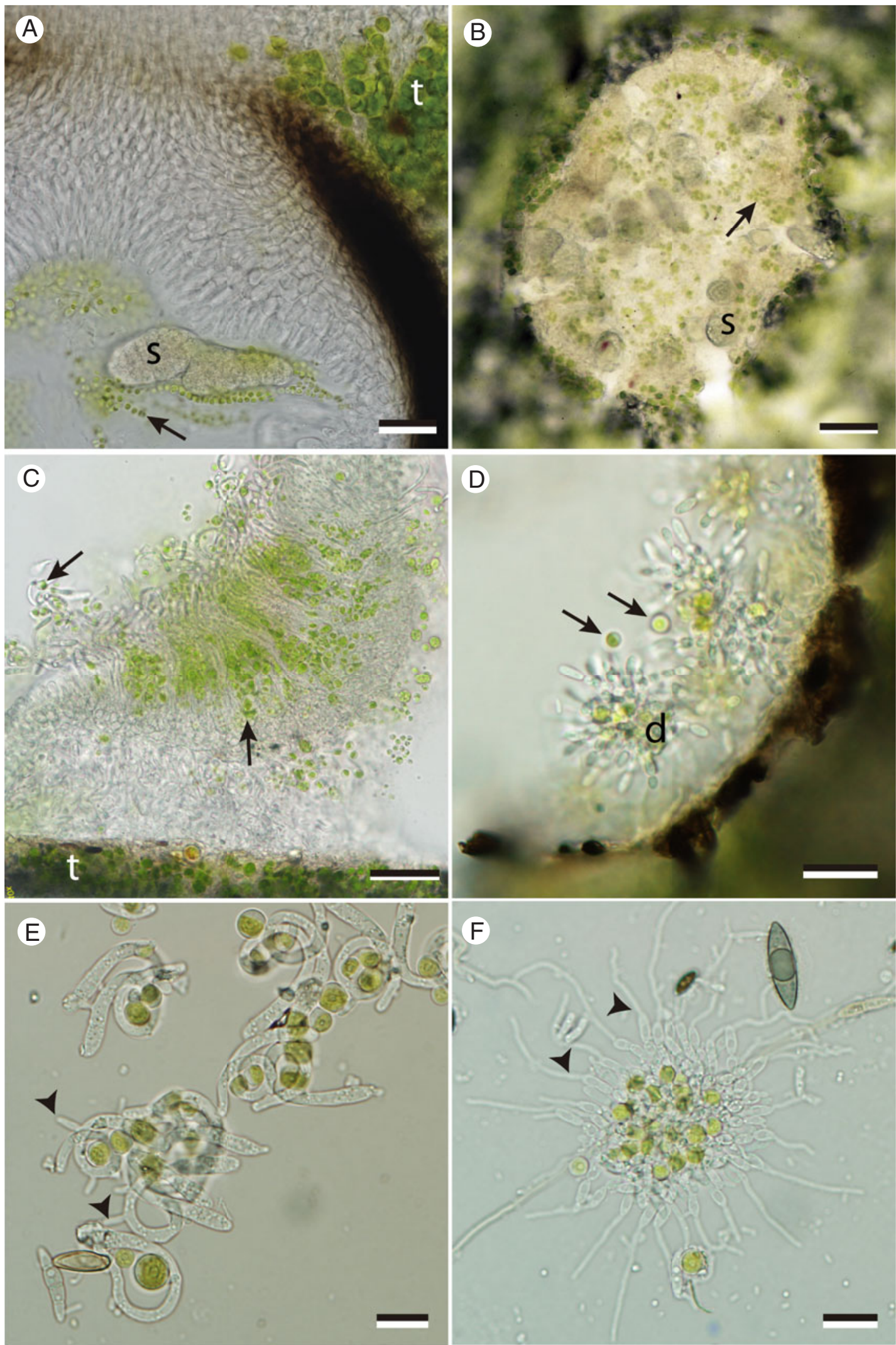

Fig. 3. Liberation and potential co-dispersal of photobionts from the spore-producing structures of certain mycobionts. A, Diplosphaera photobiont (arrows) within perithecium of Endocarpon pusillum; note much smaller size compared to photobiont cells within thalline tissue (t); $\mathrm{s}=$ ascospore. B, apothecial surface of foliicolous lichen colonizing plastic cover slip; note epithecial algal cells (arrows) among emerging ascospores (s). C, Heveochlorella photobionts (vertical arrow) within conidiogenous tissue of campylidia and intermixed among filiform macroconidia (oblique arrow). D, hyphophore of Gyalectidium paolae showing diahyphal propagules (bundles of conidial chains dispersed as a unit) with adhering or intermixed Heveochlorella photobionts (arrows). E, campylidial macroconidia, with co-dispersed Heveochlorella photobionts loosely encircled, germinating (arrowheads) on a plastic cover slip. F, diahyphal propagules of Gyalectidium germinating (arrowheads) on a plastic cover slip, with co-dispersed Heveochlorella photobionts. Scales: A, C \& D = 20 $\mu \mathrm{m} ; \mathrm{B}=50 \mu \mathrm{m} ; \mathrm{E} \& \mathrm{~F}=10 \mu \mathrm{m}$. 


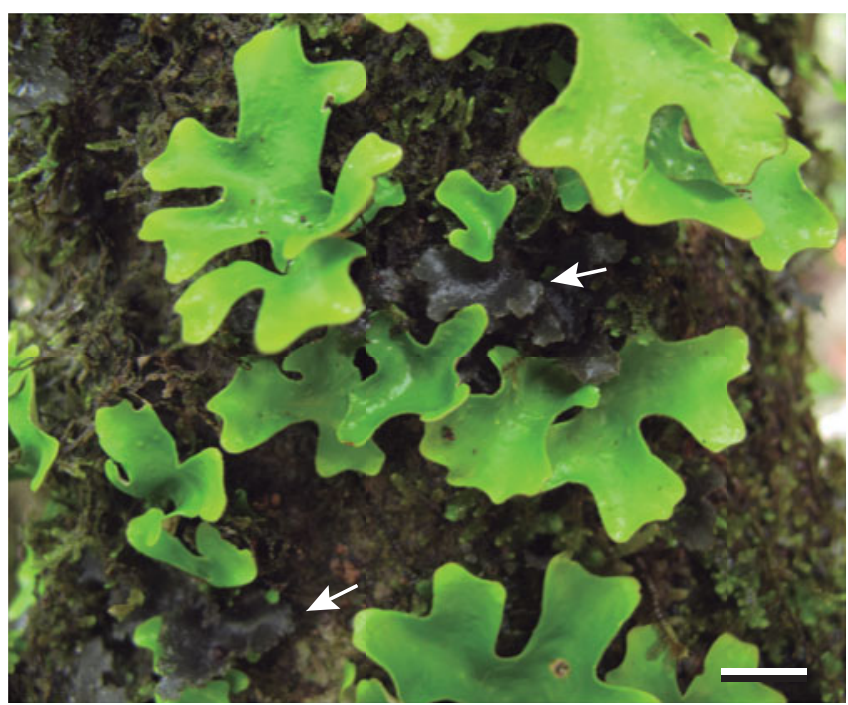

Fig. 4. Dichotomously lobed chloromorphs of Sticta canariensis emerging from lower surfaces of cyanomorph thalli (arrows). Scale $=5 \mathrm{~mm}$.

containing thallus, or distinct cyanomorph and chloromorph thalli separately or conjoined (Fig. 4) via a common fungal individual (e.g. James \& Henssen 1976). Association with both a chlorobiont and a cyanobiont in separate thallus components has also been reported for certain basidiolichen species in Cyphellostereum (Oberwinkler 2012) and Lichenomphalia (Gasulla et al. 2020). In a small number of lichens, green and blue-green photobionts are known to occur intermixed within the same thallus structure (Büdel \& Henssen 1987; Henskens et al. 2012). There are distinct physiological advantages to each of these two kinds of photobionts. Cyanobionts can fix nitrogen as well as carbon but require liquid water to rehydrate and resume physiological activity, whereas chlorobionts can rehydrate from vapour, although their $\mathrm{CO}_{2}$ fixation rates may be more adversely affected by high thallus water contents (Lange et al. 1986, 1993; Green et al. 1993, 2002). Less obvious are the implications of choosing Trentepohlia (Ulvophyceae) versus Trebouxia (Trebouxiophyceae) photobionts; neither fix nitrogen, although they may differ in their tolerance of freezing temperatures (Nash et al. 1987). Interestingly, mycobiont genera Ionaspis and Hymenelia (Lecanoromycetes) include trentepohliophilic and trebouxiophilic taxa, and the single species $H$. epulotica can apparently associate with photobionts of either of these two very different genera (Lutzoni \& Brodo 1995; McCune et al. 2018). Recently, Ertz et al. (2018) demonstrated that the lichen fungus Lecanographa amylacea can form morphologically distinct sexual and asexual thalli with Trentepohlia and Trebouxia photobionts, respectively. While the above examples show that significant divergences in photobiont selection have arisen in a number of mycobiont lineages, far more conservative tendencies appear to predominate in the majority of lichen-forming fungal groups.

Photobiont choice and the range of compatible pairings for a given mycobiont were first explored experimentally in classic laboratory resynthesis studies using Cladonia cristatella and Lecanora chrysoleuca (Ahmadjian et al. 1980; Ahmadjian \& Jacobs 1981). Varying degrees of compatibility were observed, with thallus formation reaching different developmental stages depending on the photobiont strain introduced. Nonetheless, overall results generally reflected patterns observable in natural lichens:
Cladonia successfully lichenized strains of Asterochloris but not those of Trebouxia (as currently defined), while Lecanora did just the opposite. In the last two decades, genetic markers have been used to characterize the range of photobiont diversity chosen by individual lichen-forming fungal species in nature, and to assess the parameters that might affect their choices. This complex topic has attracted much attention and merits a review of its own, but some general findings can be summarized here. Most mycobiont species appear to be fairly selective; they tend to partner with a limited range of strains or species within a single photobiont genus, but to differing degrees. Some mycobionts accept a substantially broader range of taxa within the photobiont partner genus; this relative liberality is often characteristic of lichen-forming fungi that have attained wider, more cosmopolitan distributions (Blaha et al. 2006; Guzow-Krzemińska 2006; Leavitt et al. 2013; Muggia et al. 2014; Magain et al. 2017; Vančurová et al. 2018), or those capable of colonizing extreme environments with probably fewer photobiont options available (Romeike et al. 2002; Wirtz et al. 2003; Engelen et al. 2010; Pérez-Ortega et al. 2012; Osyczka et al. 2021; Rola et al. 2021). Such mycobionts may be closely related to species that accept a much narrower range of photobiont partners (Piercey-Normore 2004; Yahr et al. 2004; Otálora et al. 2010; Onuț-Brännström et al. 2017). Some studies have correlated symbiont selection patterns with environmental parameters, such as latitude (Singh et al. 2017), climate (Řidká et al. 2014) and ecological conditions that influence the distribution and availability of photobionts (Yahr et al. 2006; Fernández-Mendoza et al. 2011; Peksa \& Škaloud 2011; Vargas Castillo \& Beck 2012; Werth \& Sork 2014). Photobiont tolerance of heavy metals appears to influence their selection by mycobionts in some lichen communities colonizing metal-rich substrata (Vančurová et al. 2018; Rola et al. 2021) but not others (Beck 2002; Hauck et al. 2007; Bačkor et al. 2010). Many studies stress the intrinsic compatibility requirements of individual fungal taxa as primary determinants of pairing patterns (Yahr et al. 2004; Stenroos et al. 2006; Myllys et al. 2007; Leavitt et al. 2015; Joneson \& O'Brien 2017), often in conjunction with ecological factors (Elvebakk et al. 2008; O'Brien et al. 2013; Dal Grande et al. 2018; Jüriado et al. 2019; Pino-Bodas \& Stenroos 2020). In some communities, mycobionts may have adapted to utilize a common pool or pools of photobionts, whose local availability might thereby be sustained for all users (Beck et al. 2002; Rikkinen et al. 2002; Rikkinen 2003; Sanders et al. 2016; Onuț-Brännström et al. 2018; Cardós et al. 2019). Thallus growth form may also affect photobiont selection patterns. Some authors have suggested that crustose lichens may associate with a broader range of photobionts than do related foliose and fruticose taxa (Helms et al. 2001), perhaps because their more extensive and intimate contact with the substratum offers more opportunity to take up additional algae in the course of development. Lichen reproductive mode can also be superimposed upon these factors. Some studies have found that lichens reproducing primarily by vegetative propagules, such as soredia or isidia, associate with a narrower range of photobiont genotypes, presumably due to chiefly vertical transmission of both symbionts together (Dal Grande et al. 2012; Werth \& Scheidegger 2012; Otálora et al. 2013; Cao et al. 2015; Hestmark et al. 2016; Steinová et al. 2019). However, other vegetatively reproducing lichens accept a much broader range of photobionts, suggesting that the fungus does not necessarily maintain partnership with its co-dispersed photobiont throughout development (Ohmura et al. 2006, 2019; Nelsen \& Gargas 2008, 2009; Wornik \& Grube 2010). 


\section{Acquisition of New Algal Symbionts}

Acquisition of new and different photobionts, 'photobiont switching', has clearly been significant in the evolution of lichen relationships. However, this phrase may refer variably to events occurring at different levels of organization. A single mycobiont individual might acquire new photobionts at different times in the course of its development (Friedl 1987; Wedin et al. 2016), or at separate places along its somatic extension (LétrouitGalinou \& Asta 1994). The degree to which the newly lichenized alga may differ genetically from algal strain(s) already in possession will be limited by the innate compatibility range of that mycobiont individual. In contrast, a new fungal individual developing from a meiospore may encounter and select a photobiont strain different from the one its parental genotypes associated with. In this case, a generational change in photobiont partner could be enabled by a generational change in mycobiont genotype. At a phylogenetic level, a cladogram may provide evidence that a fungal lineage has changed its association from one photobiont to another in the course of evolution. But at a finer scale, a great many photobiont switches, perhaps back and forth, might have taken place over many generations; comparing taxa will indicate only the overall result.

New photobionts may be acquired in multiple ways. Contact and capture of free-living photobionts in nature by hyphae emerging from germinated spores (Fig. 5), once thought to be unlikely (Lamb 1959), has been documented in a number of studies (Ward 1884; Werner 1931; Bubrick et al. 1984; Garty \& Delarea 1988; Scheidegger 1995; Sanders \& Lücking 2002; Sanders 2014). In theory, a single compatible algal individual might be sufficient to generate the entire population within a developing thallus. However, there appear to be many opportunities for additional photobionts to be incorporated from exterior sources. Particularly in early developmental stages, prothallic hyphae extending outward along the substratum from the

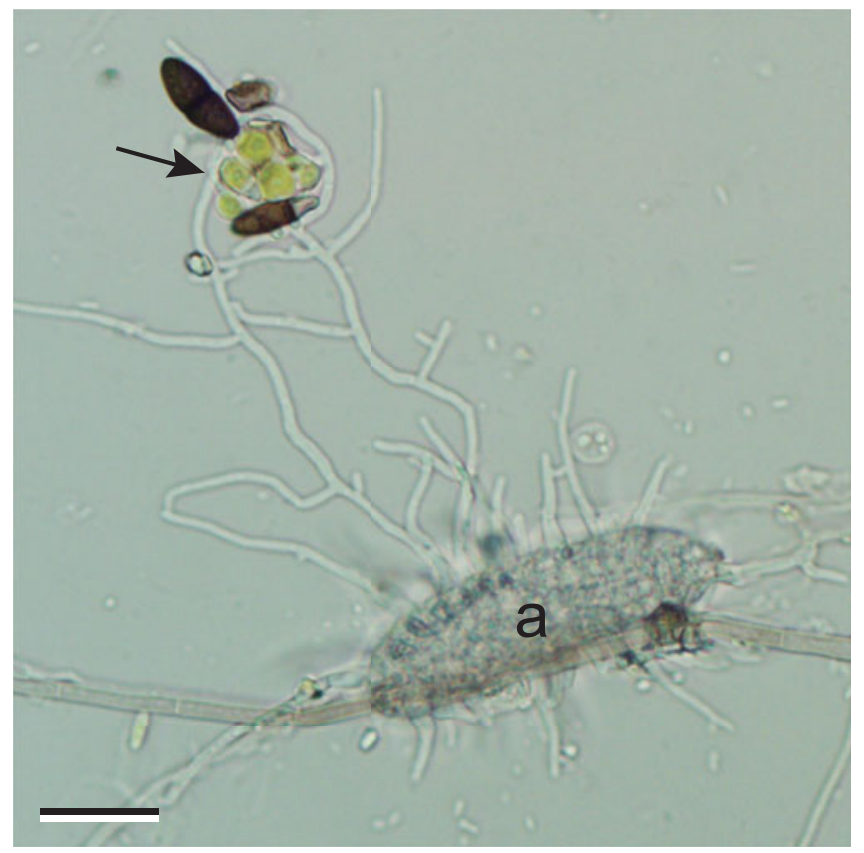

Fig. 5. Muriform ascospore (a), probably of Calopadia, germinating on a plastic cover slip placed in a south-west Florida oak hammock, and lichenizing a group of algal cells (arrow), most likely Heveochlorella. Scale $=20 \mu \mathrm{m}$. lichenized portions of the organizing thallus can incorporate additional algal cells (Sanders \& Lücking 2002; Sanders 2014). Vegetative propagules, such as soredia or isidia, also begin development with the emergence and proliferation of such hyphae (Jahns et al. 1979; Schuster et al. 1985), anchoring the structure and greatly expanding the available surfaces for potential contact with other compatible photobionts as the thallus is organized. In many crustose lichens, a prothallus remains active at the growing margins of the lichen and may continue to incorporate compatible photobionts falling upon it or encountered on the substratum (Fig. 6; see also Galløe 1927: p. 40, 1932: p. 78; Letrouit-Galinou \& Asta 1994). The multitude of discrete, lichenized units that comprise the thallus of squamulose lichens probably also arise from repeated algal capture by a network of prothallic hyphae interconnecting the squamules. Certain soil- and rock-colonizing squamulose lichens produce hyphal aggregates (cords or rhizomorphs) of indeterminate growth that penetrate the substratum extensively (Poelt \& Baumgärtner 1964; Sanders et al. 1994), giving rise to new thallus squamules where compatible algal symbionts are encountered and lichenized (Wagner \& Letrouit-Galinou 1988; Sanders \& Rico 1992; Sanders 1994). The structurally similar rhizinomorphs of certain umbilicate lichens also appear to have this capability (Schuster 1992). In some foliose and fruticose lichens, organized thallus surfaces may themselves be capable of incorporating compatible algal cells that make external contact (Bitter 1904). Lichens that form cephalodia and/or joined chloromorph and cyanomorph thalli clearly retain this ability (see discussion under Nostoc below). Additionally, certain lichen-forming fungi appear capable of obtaining photobionts from other lichens, upon which their spores may germinate (Hawksworth et al. 1979). The host thallus is eventually destroyed as its photobionts are taken over by the invading hyphae of the aggressor, giving rise to a new lichen (Poelt 1958; Friedl 1987; Feige et al. 1993; Lücking \& Grube 2002; Wedin et al. 2016). Thus, capture of free-living algae by spore germlings is clearly not the only opportunity for a mycobiont to acquire new photobionts. On the other hand, some interesting transplant experiments with Psora decipiens suggest that lichens may not always be able to switch to more favourable photobionts when needed (Williams et al. 2017).

If acquisition of additional photobionts is indeed a common occurrence in the course of lichen development, lichen thalli may be expected to contain a heterogeneous photobiont population, at least at certain stages. Some authors have observed and illustrated quite different chlorobionts occurring together within single thalli (Voytsekhovich et al. 2011). Data from molecular markers have also addressed this question. Some authors found no evidence of multiple photobiont genotypes in single thalli examined (Paulsrud \& Lindblad 1998; Beck \& Koop 2001; Singh et al. 2017; Škaloud et al. 2018); others found occasional occurrences (Guzow-Krzemińska 2006; Bačkor et al. 2010; Muggia et al. 2013; Nyati et al. 2013; Ridka et al. 2014; Onuț-Brännström et al. 2018; Vančurová et al. 2018; Molins et al. 2020), or frequent presence (Piercey-Normore 2006; Muggia et al. 2014; Park et al. 2015; Dal Grande et al. 2018; Osyczka et al. 2021). Intrathalline populations of Trebouxia can also vary in simple sequence DNA regions, which may result from clonal replication errors (Mansournia et al. 2012; Dal Grande et al. 2014a). Individual thalli of Parmotrema pseudotinctorum from the Canary Islands were reported to encompass distinct lineages of Trebouxia as well as Asterochloris (Molins et al. 2013). According to Casano et al. (2011), two genetically distinct strains of Trebouxia are always present together in thalli of 

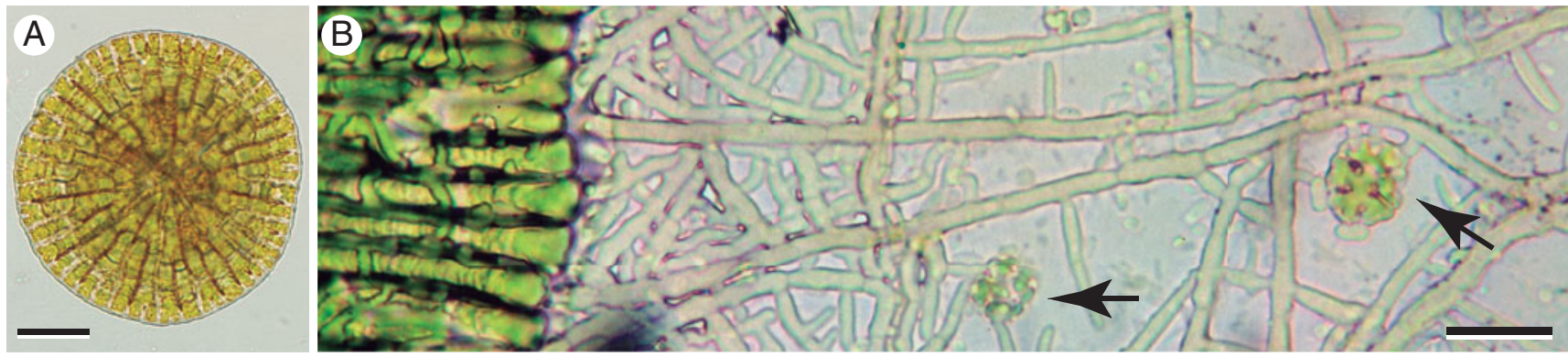

Fig. 6. Phycopeltis free-living and in stages of lichenization. A, free-living. B, edge of developed Phycopeltis thallus (left) lichenized by a network of hyphae (probably foliicolous Porina sp.) that extend over substratum and capture additional young Phycopeltis germlings (arrows). Scales: $A=20 \mu \mathrm{m} ; \mathrm{B}=10 \mu \mathrm{m}$.

Ramalina farinacea, and high-throughput sequencing results suggest that a number of other, minority algae might also be present in this lichen (Moya et al. 2017). One constant challenge in assessing photobiont identities is that lichen thallus surfaces are colonized by epibiontic algae (including possible photobionts of other lichens) that are not intimate symbionts of the lichen in question, yet may figure prominently in cultures established or samples obtained from thallus fragments (Warén 1920; Muggia et al. 2013). Confidence that sampled algae are indeed the thallus photobionts can be improved by establishing cultures from single algal cells extracted from within the thallus using a micromanipulator (Beck \& Koop 2001), although the procedure is time-consuming. Additional evidence may be sought in TEM micrographs of photobionts within the same thallus (e.g. Catalá et al. 2016; Molins et al. 2018), particularly where more than one pyrenoid type (Friedl 1989) is present. However, variability should first be assessed among individuals of the same genetic strain because chloroplast structure may vary from cell to cell and often looks substantially different according to the plane of ultrathin section examined. In sequencing, conventional dideoxy chain termination (Sanger) technology will reliably identify a predominant photobiont and ignore any others present in low abundance, while the procedure fails if there are secondary photobionts in sufficient abundance (c. 30\%; Paul et al. 2018). High-throughput sequencing will detect minority photobionts but will also be more sensitive to epibiontic algae. A recent comparison of the two sequencing approaches concluded that in most lichens there is a single dominant photobiont genotype, representative of most of the thallus population (Paul et al. 2018).

\section{The Genera of Lichen Algae}

Approximately 50 algal genera are currently said to include lichen photobionts. Some may represent identifications that are erroneous or based on outdated circumscriptions of taxa. Others may spin off new genera as their cryptic genetic diversity is further elucidated. It is evident that a small number of very prominent photobiont genera (Asterochloris, Nostoc, Rhizonema, Trebouxia, Trentepohlia) each partner with many hundreds or thousands of lichen-forming fungal species; a number of others (e.g. Coccomyxa, Elliptochloris, Heveochlorella, Symbiochloris) are lichenized by many dozens or hundreds of different mycobiont species, while much of the remainder participate in only a small number of known lichen associations. It seems probable that further surveys will uncover more photobiont genera in the latter category. While it is widely agreed that the diversity of lichen-forming algae remains considerably less well known than that of lichen-forming fungi, this fact alone is unlikely to account for the enormous disparity between the currently recognized number of photobiont genera (c. 50) and that of mycobiont genera (c. 1000; Lücking et al. 2017a). The number of photobiont species described, estimated at $c .100$ not long ago (Škaloud \& Peksa 2010), shows a similar disparity with the number of lichenforming fungal species $(20000)$. Indeed, both the generic and species estimates differ between mycobiont and phycobiont by the same factor of 20. Thus, the imbalance is not likely due to differences in genus/species concepts between algae and fungi. Of course, much of the genetic diversity discovered within photobiont genera in the last few years has been reported as clades that still lack taxonomic recognition; species numbers will surely increase substantially in the near future as such diversity becomes formalized biosystematically. However, this still seems unlikely to close the enormous gap with mycobiont species numbers. Rather, the disparities probably indicate a real ecological asymmetry: the large number of lichen-forming fungal taxa may be partnering with a substantially smaller pool of photobiont taxa, many of which are shared among mycobionts. Such was the conclusion reached recently by Dal Forno et al. (2020) in their detailed comparison of genetic diversity in Dictyonema and its Rhizonema photobionts.

A synopsis of algal genera to which lichen photobionts are currently attributed is given below.

\section{Cyanobacteria}

Anabaena Bory ex É. Bornet \& C. Flahault - See Nostoc. Strains of Anabaena versus Nostoc are resolved in some analyses (Henson et al. 2002; Rajaniemi et al. 2005; Liu et al. 2013; Elshobary et al. 2015) but formal distinction of the two genera remains controversial (Makra et al. 2019). Tschermak-Woess (1988a) recommended re-examination of earlier reports that Anabaena occurs as cephalodial photobiont of Stereocaulon.

Anacystis Meneghini - According to Bold \& Wynne (1985), this generic name has been applied to ellipsoid to cylindrical cyanobacteria that often accumulate in a common gelatinous matrix, with some authors also including spheriodal-celled taxa such as Gloeocapsa and Chroococcus. The much-studied 'Anacystis nidulans' is usually treated now under Synecococcus; other taxa are currently placed in Microcystis. Photobionts attributed to Anacystis in the past include the partners of a small number of Peltula species and the cephalodial symbionts of a 
Stereocaulon (see Tschermak-Woess 1988a); determining their identities with confidence will require further study.

Brasilonema Fiore et al. - This cyanobacterial genus, forming a distinct clade in molecular analyses (Fiore et al. 2007), has aggregated filaments morphologically similar to Scytonema but only rarely showing false branching. A recent paper reported new species of both Brasilonema and Chroococcidiopsis as co-occurring photobionts of an unidentified lichen growing on gravestones in a northern Florida cemetery (Villanueva et al. 2018). However, as no description or evidence of this association has yet been published, the status of Brasilonema as lichen photobiont awaits corroboration.

Calothrix C. Agardh ex É. Bornet \& C. Flahault and Dichothrix G. Zanardini ex É. Bornet \& C. Flahault - These filamentous cyanobacteria are members of the Rivulariaceae; their trichomes have a basal heterocyte and gradually narrow towards the apex. The two genera are morphologically similar and both have been reported as lichen photobionts, particularly in association with certain species of Lichina (see TschermakWoess 1988a). However, DNA sequences obtained from two such examples instead placed the algae in question in the genus Rivularia (Ortiz-Âlvarez et al. 2015). The photobiont of Placynthium nigrum isolated into culture also shows the distinctive Rivulariaceae morphology (apically tapering filaments with basal heterocytes) while the lichenized filaments rather resemble those now placed in Rhizonema (see Geitler 1934). The circumscription of Calothrix and Dichothrix with respect to lichen photobionts currently remains unresolved.

Chroococcidiopsis Geitler (and Myxosarcina H. Printz) - These unicellular cyanobacteria are found in a great diversity of habitats and include extremophiles. Cells divide in sequence by binary fission, often in alternating planes to produce more or less cubical packages of cells. Cells can also undergo multiple fission to produce four or more autospore-like products known as baeocytes, initially contained within the sheath-like, fibrous outer wall layer of the mother cell (Waterbury \& Stanier 1978). The baeocytes of Myxosarcina, unlike those of Chroococcidiopsis, have a brief stage of gliding motility; the genera are said to be otherwise indistinguishable morphologically. The baeocyteforming cyanobacteria were formerly grouped together in the order Pleurocapsales (Waterbury \& Stanier 1978), but SSU sequence analysis has shown this trait to be a convergence shared by a number of lineages of quite different origin (Fewer et al. 2002). In that study, several photobionts isolated from Lichinaceae appear within the same clade as Chroococcidiopsis thermalis, sister to the heterocyte-forming Stigonematales and Nostocales, and distant from Myxosarcina as well as other morphologically similar taxa formerly attributed to Chroococcidiopsis (Fewer et al. 2002). Sequences obtained from photobionts of several Peltula species collected in Vietnam also suggested affinities within a broad 'Chroococcidiopsidales' clade (Võ 2016). Other algal partners of Lichinaceae have been attributed to Chroococcidiopsis based on morphology and the production of baeocytes observed in cultured isolates (Büdel \& Henssen 1983). Tschermak-Woess (1988a) suggested that some taxa identified as Chroococcidiopsis might actually belong to Gloeocapsa and require study in culture. Most photobiont isolates attributed to Chroococcidiopsis and Myxosarcina await more detailed molecular scrutiny.
Chroococcus Nägeli - A morphologically distinctive cyanobacterial genus, Chroococcus has relatively large, spherical cells that divide at consecutive right angles to produce small packets of cells, often within concentric, gelatinous sheath layers. A number of reports, compiled by Tschermak-Woess (1988a), attribute thallus and cephalodial photobionts of various lichens to this genus or merely to Chroococcaceae, or Chroococcales. Many are anecdotal and most await reinvestigation with molecular sequence comparisons. The photobionts of certain Dictyonema species, once attributed to Chroococcus, have been shown to belong instead to Rhizonema, a usually filamentous taxon that may be greatly altered morphologically in certain lichen associations (Lücking et al. 2009). The circumscription of Chroococcus and its status as a lichen photobiont genus remain uncertain at present.

Gloeocapsa Kützing - This colonial cyanobacterium has roundish to oblong cells surrounded individually and communally by successive layers of dense mucilage, reflecting the sequence of cell divisions. Morphologically defined at present, Gloeocapsa commonly occurs free-living in moist terrestrial habitats and is also reported as thallus photobiont in several genera of Lichinaceae, and as cephalodial symbiont in certain species of Stereocaulon and Amygdalaria (Tschermak-Woess 1988a). In the lichen Gonohymenia, contacting mycobiont hyphae broadly invaginate the cells of its photobiont, identified as Gloeocapsa (Paran et al. 1971). Geitler (1933) described appressorial hyphae in the lichen Synalissa that branch in synchrony with the binary fission of its Gloeocapsa photobiont.

Molecular sequence data are much needed to understand the relationship among taxa currently assigned to Gloeocapsa.

Hyella É. Bornet \& C. Flahault - The filamentous cyanobacterium Hyella is a widespread inhabitant of the marine intertidal zone, where it colonizes calcareous substrata such as mollusc shells. The substratum is penetrated by threads arising from a basal system at the surface; endospore-like baeocytes may be formed (Fritsch 1945). Genomic analysis shows Hyella phylogenetically nearest to the genus Chroococcidiopsis (Brito et al. 2020). Hyella is reported to be the photobiont of some species of fungi now assigned to Collemopsidium (Mohr et al. 2004). However, details of the symbiotic interaction are few; other genera of cyanobacteria, such as Gloeocapsa and Nostoc, are also said to be photobionts for Collemopsidium [=Pyrenocollema] (Purvis et al. 1992).

Hyphomorpha A. Borzi - These seldom encountered cyanobacteria occur as epiphytes upon tropical liverworts and tree bark, where they form a prostrate filament system. The filaments have an apical cell producing derivatives that may later divide periclinally to become pluriseriate, as do structurally similar species of Stigonema. Cells of these older portions tend to fall out of alignment and become jumbled into a 'chroococcoid stage' (Fritsch 1945). Hyphomorpha was first identified as photobiont in two species of Spilonema lichens by Henssen (1981), who reported confirmation of the alga's identity by eminent phycologist Lothar Geitler. One of these mycobiont species has been recently reclassified as Erinacellus dendroides (Spribille et al. 2014). At present, the algal genus Hyphomorpha is phenotypically defined; it is currently placed in Fischerellaceae (Büdel \& Kauff 2012) or included under Hapalosiphonaceae (Komárek et al. 2014) within the Nostocales. 
Nostoc Vaucher ex É. Bornet \& C. Flahault - This genus accommodates cyanobacteria occurring worldwide in fresh water and upon soil, bark and low-growing plants, with some strains highly desiccation-tolerant (Dodds et al. 1995). Phenotypically defined at present, taxa attributed to Nostoc fall within several distinct clades of the Nostocales, making the genus polyphyletic (Rajaniemi et al. 2005; Gagunashvili \& Andrésson 2018). These algae typically form darkly pigmented, mucilaginous macrocolonies of highly variable size and shape, ranging from spheres to irregularly pustulose mats to tangles of cord-like axes. Embedded within the gelatinous matrix are uniseriate trichomes markedly constricted at the cross walls, giving individual cells an almost spherical to barrel-shaped form and the filaments a characteristic string-of-beads appearance. Cell division is diffuse, without apical cells or directional polarity. At intervals along the chain of vegetative cells are slightly larger, thicker-walled, lighter-coloured heterocytes (heterocysts) that specialize as centres of nitrogen fixation. Since the enzyme involved in this process is inhibited by the presence of oxygen, heterocytes lack oxygen-generating Photosystem II (Wolk et al. 1994); electron donors are imported and fixed nitrogen is exported via microplasmodesmatal connections with neighbouring vegetative cells (Giddings \& Staehelin 1981; Kumar et al. 2010). Thus, prokaryotic Nostoc and its heterocytic relatives show degrees of cell specialization and intercellular transport characteristic of true multicellular organization (Garcia-Pichel 2009).

Nostoc, like many filamentous cyanobacteria, has a motile phase. Short filament segments known as hormogonia are produced by multiple divisions of the vegetative cells between two heterocytes, then break free (Boissière et al. 1987; Paulsrud 2001). The segments disperse or migrate directionally by a gliding motion that involves secretion of polysaccharide, against which proteinaceous pili appear to push or pull the trichome (Khayatan et al. 2015). Under favourable conditions, the hormogonia lose motility and differentiate heterocytes as they transition to vegetative filaments (Paulsrud 2001). It is conceivable that motile hormogonia might facilitate symbiont encounters in the formation of cyanolichens, as also suspected of flagellate stages in eukaryotic photobionts, but direct evidence is lacking. In the establishment of plant-Nostoc symbioses, the role of hormogonia as infective agents is well known (Adams et al. 2012), and genes related to hormogonial function have been identified in lichen-symbiotic strains (Gagunashvili \& Andrésson 2018). Nostoc may also disperse temporally by forming akinetes, a kind of resistant spore that develops from a vegetative cell and endures adverse conditions.

Nostoc is photobiont in the majority of cyanophilic lichens. In the Peltigerales, Nostoc serves as principal thallus photobiont, or as secondary photobiont specialized for nitrogen fixation within discrete structures known as cephalodia; these are formed upon or within a thallus that has a green alga as principal photobiont. In a number of cases, Nostoc may serve as both principal and secondary photobiont of a single mycobiont species or individual; this results in cyanomorph and cephalodiate chloromorph thalli that may be either separate or conjoined (James \& Henssen 1976; Brodo \& Richardson 1978; Tønsberg \& Holtan-Hartwig 1983; Armaleo \& Clerc 1991; Stenroos et al. 2003; Moncada et al. 2013; Simon et al. 2018). The same strain of Nostoc may occur in both morphs (Paulsrud et al. 1998, 2001). In many such instances, chloromorph and cyanomorph are both foliose, but in some species of Lobaria and Sticta, the Nostoc-containing cyanomorph is a branching, fruticose growth that bears no resemblance to the foliose chloromorph (Jordan 1972; James \& Henssen 1976; Tønsberg \& Goward 2001; Magain et al. 2012); when growing separately, the two morphs were long presumed to represent very different taxa. Thallus morphology would appear to be influenced by the distinct photobionts in such cases. In certain species of Pseudocyphellaria on the other hand, the independently growing 'cyanomorphs' include numerous clusters of the green algal symbiont (probably Symbiochloris) spread among the Nostoc within the algal layer (Henskens et al. 2012), with no visible alterations to thallus morphology. Even when Nostoc serves as a secondary (cephalodial) photobiont in a mature lichen, it may be acquired at a very early stage of lichen formation through contact and capture by the developing mycobiont prothallus (Ott 1988; de los Ríos et al. 2011). Once organized, thallus lobes containing green algae may secondarily encounter and incorporate compatible Nostoc on the lower surface (Jordan 1970; Jordan \& Rickson 1971), or either the upper or lower surface (Cornejo \& Scheidegger 2013). Mycobiont selectivity for particular strains of Nostoc can be very high (Paulsrud et al. 2001). The Nostoc-containing cyanomorph may in turn capture compatible green algal symbionts that contact the tomentum hyphae of the lower cortex, from which chloromorph lobes arise (Sanders 2001).

In most lichens where it is primary photobiont, Nostoc is confined to a discrete algal layer; its filaments are often broken up or contorted into cell clusters with little secretion of mucilaginous sheath material (Fig. 1J). When isolated into culture, it reverts to the morphology and growth pattern typical of its free-living state (Kardish et al. 1989). However, in many of the so-called gelatinous lichens, the form of the Nostoc is not fundamentally altered in lichenization; it maintains the necklace-like filaments and extensive surrounding gelatinous sheath, through which the mycobiont hyphae penetrate (Fig. 1I). In such cases, the photobiont constitutes the main structural component of the lichen, which may maintain an appearance and texture rather similar to that of free-living Nostoc macrocolonies. A recent study suggests that these differences in phenotypic expression, leading to stratified versus gelatinous lichens, may be associated with different genetic strains of Nostoc (Magain \& Sérusiaux 2014). This would appear to be another example where major differences in thallus structure may be correlated with photobiont identity.

Cyanophilic mycobionts can be highly selective of their Nostoc partner strains, often overriding geographical factors (Paulsrud et al. 1998, 2000; Stenroos et al. 2006; Myllys et al. 2007), although a considerably lower selectivity was observed in lichen communities in maritime Antarctica (Wirtz et al. 2003). Within a single clade of Peltigera, both highly selective and less discriminating generalist species can be recognized (Magain et al. 2017, 2018). A study of temperate and boreal communities reported genetically distinct terricolous and epiphytic pools of Nostoc, from which Peltigera and Nephroma spp. colonizing those respective substrata select their photobionts (Rikkinen et al. 2002). Using a larger data set, Stenroos et al. (2006) found Nostoc photobiont strains to be correlated with mycobiont identity rather than ecological guild. However, fungal preference for the Nostoc photobiont strains of other community members over those sampled from the substratum has been reported in other lichen communities (Cardós et al. 2019). In other studies, involving 
Pannaria and other cyanophilic lichens, both corticolous and saxicolous species sometimes chose closely related strains of Nostoc, and more complex combinations of variable mycobiont selectivity and ecological factors were observed (Elvebakk et al. 2008).

Nostoc participates in a range of symbioses besides those it forms with lichen-forming fungi (Adams et al. 2012). It is taken up by the locally emergent protoplast of the coenocytic, glomeromycete fungus Geosiphon pyriformis, which then produces a swollen bladder within which the endosymbiotic (endocytobiotic) Nostoc is housed. The intracellular location of the algal symbiont and the close affinities of the fungal component to arbuscular mycorrhizal fungi make the Geosiphon-Nostoc symbiosis quite distinct from fungal-algal symbioses treated under the lichen concept (Kluge et al. 2002; Schüßler 2012). Nostoc also includes obligatory partners of plants representing several major clades of embryophytes; motile hormogonia are the usual infective agent, and fixed nitrogen, usually in the form of ammonium, is supplied to the host from the numerous heterocytes that differentiate in the symbiotic state (Meeks 1998). In hornworts and the liverwort Blasia, hormogonia enter and inhabit specialized, mucilage-secreting chambers within the gametophytes (Adams \& Duggan 2002). Branched filamentous outgrowths from the inner surfaces of these chambers then develop and increase surface contact between the host and the cyanobacterial colonies (Rodgers \& Stewart 1977). In cycad gymnosperms, Nostoc colonizes radial cavities in the cortex of specialized, upward-growing coralloid roots (Costa \& Lindblad 2002). Symbiosis with the floating aquatic fern Azolla is unique in that the Nostoc (or Anabaena; Svenning et al. 2005) is vertically inherited through plant generations, obviating the need for new symbiont capture; the principal cyanobacterium involved cannot be cultivated separately, since its genome shows considerable gene degradation (Ran et al. 2010). In the angiosperm Gunnera, symbiotic Nostoc occurs intracellularly in leaf base tissue (Bergman et al. 1992). Some of these symbiotic strains, as well as free-living isolates, appear to be similar or closely related to those occurring within lichen thalli or cephalodia, whereas certain other Nostoc strains might be more specialized as lichen photobionts (O’Brien et al. 2005; Stenroos et al. 2006). Recent genomic comparisons identified certain genes of potential relevance to symbiosis in Nostoc, suggesting also that symbiotic strains may have larger genomes than non-symbiotic ones (Gagunashvili \& Andrésson 2018).

Rhizonema Lücking \& Barrie - This cyanobacterial genus was resurrected recently to accommodate filamentous, heterocyteproducing photobionts previously assumed to belong to Scytonema, but distinct from that lineage in their 16S rRNA sequences (Lücking et al. 2009). Rhizonema species may be boreal as well as tropical; they are at present known mainly from lichen symbioses but free-living or liverwort-associated populations have also been reported (Cornejo et al. 2016). The filaments may be broken up into cell clusters or remain as discrete trichomes (Fig. 1E \& F), with sporadic lateral proliferation that has been interpreted as true branching based on the appearance of a mature branch junction (Lücking et al. 2014). This would presumably distinguish Rhizonema from Scytonema, which shows false branching. Thus, when Võ (2016) observed paired false branching in photobionts of Vietnamese Cyphellostereum and Dictyonema, she concluded that the algae were Scytonema rather than Rhizonema, apparently without corroborating molecular data. However, recent observations of Rhizonema, isolated into culture from Dictyonema and identified with genetic sequence comparisons, show branching that appears distinctly false (Fig. 1D). Interestingly, a 19th century illustration of a Dictyonema sericeum thallus (Bornet 1873: plate 12) depicted the photobiont with both double-false branching and seemingly true branching with a junction similar to that shown in Lücking et al. (2014). The range of branch development modes possible in Rhizonema strains clearly requires further study in both lichenized and aposymbiotic material.

Major genera of lichen-forming fungal partners known so far include Coccocarpia, Erioderma (Peltigerales), and the basidiomycetes Acantholichen, Dictyonema, Cora, Corella and Cyphellostereum (all Hygrophoraceae). In those basidiolichens, the Rhizonema trichome is usually penetrated longitudinally by a single, central mycobiont haustorium quite unlike anything reported in other lichen groups (Roskin 1970; Oberwinkler 1980, 1984, 2012; Slocum 1980; Tschermak-Woess 1983). Such elaborate intrusive structures differ dramatically from the very limited penetrations known in other lichenized algae and might represent specialized absorptive structures. Carbon transfer has not yet been studied in basidiolichens.

Rivularia C. Agardh ex É. Bornet \& C. Flahault - The trichomes of this cyanobacterial genus occur in clusters, often on submerged rocks; each filament has a heterocyte at the base and tends to taper gradually towards the apex. The genus includes the photobionts of a couple of maritime species of Lichina, whose algal symbionts were previously attributed to the morphologically similar genus Calothrix (Ortiz-Álvarez et al. 2015).

Scytonema C. Agardh ex É. Bornet \& C. Flahault - This aquatic or aerophilic genus of cyanobacteria has trichome walls unconstricted at the septa, with vegetative cells usually wider than long, prominent heterocytes, and thick sheaths that are often darkly pigmented. Scytonema is traditionally recognized by the frequently paired ('double') false branches, where segments created by a break in the trichome continue linear growth by simply reorienting laterally and emerging from their formerly common sheath. Trichome breaks may arise where intercellular material is deposited as a separation disc, or one or more cells degenerate, or at intercalary heterocyte positions (Bhâradwâja 1933). Once considered a significant photobiont genus, including both principal and secondary (cephalodial) lichen symbionts, Scytonema in its current sense encompasses an uncertain but much reduced number of lichen algae. Photobionts previously ascribed to Scytonema have been shown by DNA sequence analyses to belong to a quite distinct clade, now designated Rhizonema (Lücking et. al. 2009). Nevertheless, at least one recent photobiont sequence (16s rRNA), from a Heppia thallus, appears to fall within Scytonema in the strict sense (Võ 2016). This may provide some corroboration for previous attributions of Heppia photobionts to Scytonema based on morphology of cultured isolates (Wetmore 1970). The cell shape and division planes of the Heppia photobionts are radically transformed to produce cell clusters in the lichenized state, reverting quickly to typical filamentous growth when cultured aposymbiotically (Marton \& Galun 1976). In 
Pyrenothrix nigra, the lichenized filamentous cyanobiont shows the double-false branching typical of Scytonema (Tschermak-Woess et al. 1983), although Lücking et al. (2009) suggested that its photobiont might be Rhizonema. This is quite plausible, since there is some doubt as to whether the two cyanobacterial genera can be reliably distinguished by their mode of branching (see comments under Rhizonema). More sequence data are clearly needed to clarify the extent to which lichen symbioses may involve the genus Scytonema in its current, more restricted sense.

Stigonema C. Agardh ex É. Bornet \& C. Flahault - This cyanobacterial genus is recognized by its complex, branching axes with cells dividing in perpendicular planes as in true parenchyma. Filaments are uniseriate at the apex but become locally multiseriate proximally by periclinal divisions, often but not necessarily associated with the formation of true branches laterally. After division, cells retain continuity at the central portion of the septum, where micropores traverse the septal wall (Butler \& Allsopp 1972). Stigonema has been reported as thallus photobiont in Ephebe and Spilonema, and also as cephalodial partner in numerous species of Stereocaulon (Tschermak-Woess 1988a). The genus awaits molecular treatment, remaining morphologically defined for the time being.

Tolypothrix Kützing ex É. Bornet \& C. Flahault - These are filamentous cyanobacteria resembling Scytonema but with usually single- rather than double-false branches emerging from filament breaks; one side of the break grows out as the false branch, the other usually differentiates as a heterocyte. Tolypothrix has been reported as photobiont of the 'primitively lichenized' Thermutopsis jamesii based on morphology in collected material (Henssen 1990). Molecular sequences obtained from cephalodia of Placopsis placed the cyanobionts in or near Tolypothrix (Raggio et al. 2012).

\section{Green algae (Viridiplantae - Archaeplastida)}

Apatococcus F. Brand - Abundant and widely distributed as a free-living organism, Apatococcus has long been known as an omnipresent subaerial unicellular alga, inevitably encountered but not chosen by discriminating germling hyphae of lichenforming fungi. Now it appears that Apatococcus includes lichen symbionts as well. Light microscopic observations of algal symbionts cultured from several maritime lichen species first implicated Apatococcus as a photobiont (Watanabe et al. 1997); molecular sequence comparisons later identified Apatococcus strains as partners of Scoliciosporum (Beck 2002) and Fuscidea species (Zahradníková et al. 2017). Cells are spherical with alternating perpendicular planes of division, producing cuboidal packets of transiently adherent daughter cells. Autospores and biflagellate zoospores are also formed (Ettl \& Gärtner 2014). Autospores may be of unequal size within a sporangium (Gärtner \& Ingolić 1989), as also occurs in Watanabalean genera such as Chloroidium and Jaagichlorella. As with Elliptochloris and Trebouxia, Apatococcus is facultatively heterotrophic: it is very slow growing in culture unless carbohydrate is supplied (Gustavs et al. 2016). This observation is particularly interesting because the similarly heterotrophic behaviour of Trebouxia in culture was central to Ahmadjian's $(1988,2002)$ argument that Trebouxia cannot exist free-living. The seemingly ubiquitous Apatococcus shows quite clearly that a photobiont exhibiting strongly heterotrophic tendencies in culture may nonetheless abound free-living in nature.

Asterochloris Tschermak-Woess - First described to accommodate the trebouxioid photobiont of a single lichen in the Pertusariaceae (Tschermak-Woess 1980a), this major photobiont clade now encompasses the former Trebouxia subgenus Eleutherococcus (Tschermak-Woess 1989; Škaloud \& Peksa 2010). It corresponds roughly to Archibald's (1975) restricted concept of genus Trebouxia, a source of continual confusion. Asterochloris species produce aplanospores, or zoospores in culture, but most strains do not form the appressed, lownumber autospores characteristic of Trebouxia in the current sense. Its deeply-lobed chloroplast becomes flattened and parietal during cell division, while that of Trebouxia remains more or less central (Tschermak-Woess 1989). Pyrenoids are present; in TEM they may be distinguished as the irregularis-, erici-, or magna-types of Friedl (1989). Chloroplast morphology is highly variable and its utility as a marker in species delimitation was emphasized by Škaloud et al. (2015). As with Trebouxia, a considerable amount of genetic diversity is revealed at the molecular level in Asterochloris (Škaloud \& Peksa 2010; Peksa \& Škaloud 2011)

Sexual fusion of biflagellate isogametes to form a quadriflagellate zygote has been documented in cultures of $A$. woessiae (Škaloud et al. 2015). The detection of genes specific to meiosis in A. glomerata (Armaleo et al. 2019) provides further support for a functioning sexual cycle in Asterochloris.

Asterochloris is associated principally with mycobionts of the Cladoniaceae, Stereocaulaceae, and the genus Lepraria. These fungal partners appear to range from moderately to rather highly selective of their Asterochloris symbionts; there is also some indication that mycobionts of different clades are choosing particular Asterochloris lineages, showing distinct climatic preferences related to rainfall regime (Peksa \& Škaloud 2011).

Auxenochlorella (I. Shihira \& R. W. Krauss) T. Kalina \& M. Puncochárová - Within the Chlorellaceae, Auxenochlorella is related to the fully heterotrophic genus Prototheca, and its type species, A. protothecoides, is also known for its heterotrophic tendencies in culture (Darienko \& Pröschold 2015). Auxenochlorella has been implicated in regard to the identity of the photobiont associated with Psoroglaena stigonemoides in the Verrucariaceae (Nyati et al. 2007; Thüs et al. 2011). Unlike Chlorella, Auxenochlorella lacks a pyrenoid. The genus also includes 'zoochlorellae' symbionts of the cnidarian Hydra that are now considered a new species, A. symbiontica (Darienko \& Pröschold 2015).

Bracteacoccus Tereg - Bracteacoccus are small, spherical unicells that have a multinucleate stage as they mature, and reproduce by zoospores or aplanospores; chloroplasts lack pyrenoids (Kouwets 1996). Currently included in the Sphaeropleales (Fučíková et al. 2014), Bracteacoccus appears at present to be the only genus of the class Chlorophyceae into which lichen photobionts have been placed with supporting DNA sequence data. The corresponding mycobionts are two species of the basidiomycete Sulzbacheromyces in the Lepidostromatales (Hodkinson et al. 2014; Masumoto 2020).

Cephaleuros Kunze ex E. M. Fries - These foliicolous relatives of Trentepohlia form macroscopic, multicellular thalli visible as 
small, fuzzy yellow-orange patches on leaves and fruit in tropical and subtropical climates. Cephaleuros species typically grow beneath the cuticle of the leaf substratum, forming rounded to lobed thalli of more or less integrated horizontal filaments. These give rise to the erect setae and sporangiophores that emerge through the overlying cuticle. Usually, Cephaleuros develops within the space it excavates between the host cuticle and epidermis; in some cases, filaments penetrate deeper among the epidermal or mesophyll cells of the leaf, provoking a localized phellogen wound response. The alga can therefore be mildly pathogenic, but it is more often described as 'parasitic', despite an absence of information concerning any nutritional exchange with the plant host. Occasionally, the alga may develop upon the leaf cuticle, like other epiphylls. The behaviour may vary according to the species of Cephaleuros or that of the host plant (Ward 1884; Suto \& Ohtani 2009; Brooks et al. 2015). Lichenization by foliicolous Strigula fungi is said to curb the alga's invasion of host tissue and its localized pathogenic effects (Joubert \& Rijkenberg 1971).

Morphologically, Cephaleuros can somewhat resemble the related foliicolous genus Phycopeltis, which is not subcuticular and generally lacks vertical hairs and complex, long-stalked sporangiophores. According to molecular sequence analyses, however, the nearest relatives of Cephaleuros lie not within Phycopeltis but rather Stomatochroon (Zhu et al. 2017), a microscopic colonizer of the leaf's substomatal cavities. While trentepohliaceous taxa currently ascribed to Phycopeltis and Trentepohlia are phylogenetically intertwined, Cephaleuros appears to be essentially monophyletic (López-Bautista et al. 2006; Rindi et al. 2009; Nelsen et al. 2011; Zhu et al. 2017).

Cephaleuros is one of the few lichen photobiont genera for which life cycle events have been observed in some detail. Thompson \& Wujek (1997) describe a haplodiplontic life cycle with heteromorphic multicellular phases. The familiar thallus corresponds to the gametophyte; fusion of gametes produces a zygote that germinates into a short-stalked, dwarf sporophyte bearing a putative meiosporangium. Flagellate meiospores presumably develop into new gametophytic thalli. The Cephaleuros gametophyte is the phase known to serve as phycobiont for the fungus Strigula. Whether or not the sporophytes can also be lichenized is unknown. Perhaps they are too highly reduced or short-lived, but the question does not seem to have been explored. On gametophyte thalli, two distinct structures produce flagellate zoospores or gametes (often called zoïds, or swarmers, when their function is uncertain or polyvalent). Zoosporangia are elevated in groups upon vertical stalks; they produce quadriflagellate zoospores that have been observed to round off, germinate and reproduce the gametophyte thallus asexually (Ward 1884; Thompson \& Wujek 1997). The mature sporangia detach readily as units of dispersal, for which both wind and insects act as vectors. On the horizontal filament system, single, usually terminal cells may enlarge to become what are referred to as gametangia; these produce biflagellate cells that may fuse sexually (Thompson \& Wujek 1997). However, other authors have been unable to observe any instances of sexual fusions in the taxa they studied, instead reporting that the biflagellate zoïds germinate directly as zoospores to form new gametophyte thalli (Suto \& Ohtani 2013).

Ward (1884) described in detail the course of lichenization of Cephaleuros by Strigula. Young germlings of Cephaleuros are often quickly overrun by the mycelium of Strigula, suppressing algal reproduction, while individuals contacted at more advanced stages of development may produce abundant sporangia from portions of its thalli remaining relatively free of mycobiont domination. Interestingly, both symbionts grow and sporulate independently upon the leaf substratum, although the fungus Strigula will produce pycnidia and perithecia only after successful lichenization. These observations highlight the flexibility of the symbionts in this particular association.

Chlamydomonas Ehrenberg - This well-known unicellular green algal genus chiefly encompasses aquatic taxa that are flagellate in the vegetative state and unlikely candidates for lichen symbiosis. However, a number of aeroterrestrial species are also known (Ettl \& Gärtner 2014). One species of Chlamydomonas (C. augustae) was described in association with the ascomycete Pyronema laetissimum, growing on leaf litter in Latvia (Skuja 1943). It was included in Tschermak-Woess's (1988a) review of phycobionts as 'facultatively lichenized'. However, Skuja (1943) distinguished this association from lichen and lichenoid symbioses, making comparisons instead with green algae known to grow abundantly on the surfaces of perennial basidiocarps. The Chlamydomonas was abundantly present among the dense hyphae below the Pyronema apothecium, but no tissue layer was differentiated, nor were any distinctive contact interfaces noted between symbionts. Skuja also mentioned that other apothecia of the same fungus were fruiting nearby without the alga present. The operculate discomycetes (Pezizales), to which Pyronema belongs, are not otherwise known to include lichen-forming members. The Pyronema-Chlamydomonas association is worthy of further investigation but seems unlikely to fit the criteria usually ascribed to lichen symbioses.

Chlorella Beijerinck - A once-notorious miscellany of indistinguishable 'little round green things', this trebouxiophycean genus has been radically deconstructed, particularly with the help of DNA sequence comparisons (Huss et al. 1999). Many formerly included species have been moved to different genera, orders, even classes, while taxa surrounding the type species C. vulgaris, and C. sorokiniana, are retained as true Chlorella. In TEM, they show a distinctive pyrenoid surrounded by a thick sheath of starch and bisected centrally by a single thylakoid (Ikeda \& Takeda 1995; Němcová \& Kalina 2000; Hoshina et al. 2010). Flagellate cells and sexual reproduction are unknown. True Chlorella also includes a number of mucilaginous, colonial forms in its current circumscription (Luo et al. 2010; Bock et al. 2011). Many of the lichen photobionts previously attributed to Chlorella s. lat. (e.g. Tschermak-Woess 1988b) are among those taxa moved to other genera, especially Chloroidium; others await re-examination. At present, only a couple of lichen-forming fungal species have photobionts of corroborated placement within Chlorella (Porpidia crustulata; Li et al. 2013) or Chlorellales. The genus has also been long identified with endosymbiotic algal symbionts of diverse protists and invertebrates. Molecular sequences confirm that true Chlorella occur as endosymbionts of the ciliate Paramecium bursaria (Hoshina et al. 2004; Summerer et al. 2008) and the cnidarian Hydra (Kovačević et al. 2010), which may also utilize Auxenochlorella as its algal symbiont (Pröschold et al. 2011). Chloroplast ultrastructure likewise suggests that the green endosymbiont of the colonial ciliate Ophrydium versatile is a true Chlorella (Forsberg \& Lindblad 1996). However, the phylogenetic affinities of other 'zoochlorellae' symbionts appear to fall elsewhere in the 
Trebouxiophyceae (Lewis \& Muller-Parker 2004; Kovačević et al. 2010; Pröschold et al. 2011), while many have yet to be explored with molecular sequence comparisons.

Chloroidium Nadson - Resurrected to accommodate segregates from Chlorella s. lat. (Darienko et al. 2010), Chloroidium falls within the trebouxiophycean assemblage now formalized as Watanabeales (Li et al. 2021). Cells have a parietal chloroplast with or without a pyrenoid; in C. saccharophilum, a prominent pyrenoid with surrounding plastoglobuli and traversing membranes has been observed (González et al. 2013). Reproduction is by autospores, often of variable number and different sizes within a single sporangium. The genus encompasses diverse taxa found in a wide variety of habitats (Darienko et al. 2018), including extremophiles capable of using a variety of carbon sources (Nelson et al. 2017). Since its recent emendation, Chloroidium includes photobiont partners of a growing number of lichen-forming fungi, including some species of Gomphillaceae, Verrucariaceae, Psora, Stereocaulon and Sticta.

Chlorosarcinopsis Herndon - In the course of her studies on lichen haustoria, Plessl (1963) identified as Chlorosarcina [=Chlorosarcinopsis] minor the photobionts she isolated from two species of Lecidea, L. plana and L. lapicida. Chlorosarcinopsis has traditionally accommodated spherical unicellular green algae dividing to form cuboidal packets. According to Neustupa (2015), the genus is polyphyletic, with members scattered among the Chlamydomonadales (Chlorophyceae). As this clade is not otherwise known for lichen symbionts (but see Skuja 1943), the photobionts of the Lecidea species in question need further study.

Coccobotrys Chodat (now Uvulifera Molinari-Novoa) - This green alga forms irregular cuboidal cell packages or branched multiseriate filaments in culture (Neustupa 2015). The genus Coccobotrys was described by Chodat (1913) and emended by Vischer (1960) to accommodate the putative photobiont $C$. verrucariae isolated from a thallus of Verrucaria nigrescens. Thüs et al. (2011), on the other hand, reported Diplosphaera as photobiont of the $V$. nigrescens thallus they sampled. Coccobotrys verrucariae was also cited among algae isolated from soil crusts (Flechtner et al. 2009), and a photobiont identified with microscopy as 'probably Coccobotrys' (Canals et al. 1997) was isolated from Botrylepraria lesdainii, another member of the Verrucariales (Kukwa \& Pérez-Ortega 2010). A second species of Coccobotrys was described by Warén (1920) as the photobiont of Lecidea fuliginosa, but Tschermak-Woess (1988a) expressed doubt that the alga he described belongs in Coccobotrys. The photobiont status of species in this genus should be corroborated. Genetic sequence analyses place Coccobotrys in the Trebouxiophyceae (e.g. Thüs et al. 2011; Mikhailyuk et al. 2020), but its affinities among the defined clades within this class remain uncertain. Molinari-Novoa (2016) recently found Coccobotrys Chodat to be a later homonym of a name applied to an anamorphic basidiomycete and renamed the algal genus Uvulifera.

Coccomyxa Schmidle - This trebouxiophycean algal genus is notable for the diversity of habitats and ecological circumstances in which its species are known to occur. Environmental surveys have found Coccomyxa sequences to be among the most widely distributed OTUs, and notably well represented in cold highlatitude climates (Metz et al. 2019). It is commonly reported freeliving on terrestrial substrata and in aquatic environments, including those highly polluted with heavy metals and radioactive materials (see Gustavs et al. 2017). Coccomyxa species are subspherical to ovoid-ellipsoidal unicells, often embedded colonially in thick gelatinous sheath material with concentric layering that reflects the cell division pattern. The chloroplast is parietal, not markedly lobed, and lacks a pyrenoid. In TEM, thylakoid bands often show a distinctly longitudinal orientation over the length of the chloroplast, with interspersed starch grains (Peveling \& Galun 1976; Palmqvist et al. 1997). Flagellate cells and sexual reproduction are unknown; cells subdivide into packages of 2-8 autospores (Tschermak-Woess $1988 a)$. Recent assessments of species number within the genus range from seven (Darienko et al. 2015) to as many as 27 (Malavasi et al. 2016). The genus is thought to include the photobionts of diverse lichen-forming fungi, such as species of Icmadophila, Micarea, Nephroma, Peltigera, Solorina, the stalked-apotheciate genera Baeomyces, Dibaeis and Phyllobaeis, and the basidiomycete Lichenomphalia (Table 1). Some of these reports await confirmation with genetic sequence data. The photobionts do not form a single clade but instead represent several distinct lineages within Coccomyxa, intermixed among free-living isolates (Darienko et al. 2015). In lichen symbiosis, the cells are often more spheroidal, and extensive gelatinous sheath material is not usually produced (Tschermak-Woess 1988a). Interestingly, while the cells of Coccomyxa and Elliptochloris photobionts are tightly enveloped by mycobiont hyphae, their walls are usually not penetrated (Tschermak 1941a; Geitler 1955; Plessl 1963; but see Coppins 1983: figs 2 \& 55). This has been attributed to degradationresistant polymers resembling sporopollenin in the multilayered cell wall (Honegger \& Brunner 1981; Brunner \& Honegger 1985). However, Coccomyxa cells are fully penetrated by Aphelidium collabens, a parasitoid basal within, or sister to, the kingdom Fungi (Seto et al. 2020).

Species of the genus Coccomyxa also live in poorly understood symbioses within molluscs (Stevenson \& South 1974; Syasina et al. 2012) and echinoderms, and endocytotically within ovules and other tissues of the gymnosperm Ginkgo biloba (Trémouillaux-Guiller et al. 2002; Trémouillaux-Guiller \& Huss 2007). Molecular sequence comparisons have shown that some zoochlorellae isolated from certain strains of Paramecium bursaria correspond to Coccomyxa, while most others are true Chlorella (Hoshina \& Imamura 2008).

Deuterostichococcus Pröschold \& Darienko - A recent segregate of Stichococcus s. lat. (Pröschold \& Darienko 2020), this trebouxiophycean genus currently includes, in addition to free-living isolates, the photobiont of two Placopsis species (Beck et al. 2019) and Staurothele clopima (Hodač et al. 2016); the latter is also known to partner with Diplosphaera algae (Thüs et al. 2011).

\section{Dictyochloropsis Geitler - See Symbiochloris.}

Dilabifilum Tschermak-Woess - Polymorphic, unicellular to sarcinoid to filamentous algae with pyrenoids and quadriflagellate zoospores have been included in this ulvalean genus. They occur free-living, as photobionts, or both. Recently, Darienko \& Pröschold (2017) deconstructed Dilabifilum, recognizing at generic level several distinct clades resolved in their gene-based 
phylogenies. A number of photobionts previously contained therein are now distributed in Halofilum, Lithotrichon, Paulbroadya and Pseudendoclonium, while others await reassessment.

Diplosphaera Bialosuknia - This prasiolalean genus appears to contain the majority of the unicellular photobiont strains attributed until recently to the related Stichococcus. Apparently, the two morphologically plastic genera are often not distinguishable microscopically, although Diplosphaera may produce distinctive, adherent two-celled clusters in division. Pyrenoids may be absent (Pröschold \& Darienko 2020) or weakly visible (Ettl \& Gärtner 2014) but some taxa falling within the Diplosphaera clade, including lichen photobionts, show prominent pyrenoids in TEM (Fig. 2E). The main fungal partners of Diplosphaera are members of the Verrucariaceae. Photobiont strains compared so far appear to represent the same species and are similar to free-living collections (Pröschold \& Darienko 2020).

In association with certain lichen genera, such as Endocarpon and Staurothele, Diplosphaera photobionts 'escape' vegetative hyphal contacts and penetrate into the hymenial layer of developing perithecia, where they freely intermix among the asci (Fig. 3A). These algal cells are typically much smaller than those within the algal layer of the vegetative thallus; they scatter everywhere when a hand-cut section is water-mounted, indicating that unlike the photobionts in the vegetative thallus, those entering the perithecia are not bound in place by lichenizing contacts with the mycobiont. The unassociated photobionts may adhere to the large ascospores as they are ejected, and can be dispersed with them. Many readily detach and divide aposymbiotically; they are available to the mycobiont if the spore germinates successfully (Stahl 1877; Bertsch \& Butin 1967; Ahmadjian \& Heikkilä 1970) or might otherwise divide to form free-living populations. Potentially co-dispersable photobionts also occur in the conidiomata and ascomal epithecia of many foliicolous lichens of the Gomphillaceae and Pilocarpaceae (see Heveochlorella). Dispersal of liberated photobionts can thereby provide a direct connection between lichenized and free-living populations of the alga.

Elliptochloris Tschermak-Woess - Like its sister genus Coccomyxa, Elliptochloris has subspherical to ellipsoidal unicells with a parietal chloroplast, bearing two opposed indentations in the type species E. bilobata (Tschermak-Woess 1980b). Sexual or flagellate stages are unknown; reproduction occurs by autospores, of which there are usually two morphologically distinct types. Autosporangia may contain a low number (usually four in cultured E. bilobata) of spherical spores appressed together at flattened junctions, or more numerous (16-32) cylindrical-ellipsoidal spores (Tschermak-Woess 1980b; Darienko et al. 2016). The multilayered cell wall, as in Coccomyxa, is impregnated with degradation-resistant polymers, which are thought to explain the lack of haustorial penetration by their lichen-forming partners (Brunner \& Honegger 1985). However, haustoria have been noted in certain species of Micarea (Coppins 1983: figs 2 \& 55), a lichen-forming genus known to partner with Elliptochloris and Coccomyxa photobionts. Unlike Coccomyxa, at least some species of Elliptochloris possess pyrenoids, and layered mucilaginous sheaths are typically lacking. However, gelatinous extracellular material may be copious in free-living populations, and was observed in association with Protothelenella thalli where the photobiont population grew beyond the reach of mycobiont hyphae (Tschermak-Woess 1985).

Elliptochloris is somewhat less often reported than Coccomyxa but is known from a similarly diverse array of habitats. It is said to be quite strongly heterotrophic in culture, where it depends heavily on organic materials to thrive; this might in part account for its less frequent recovery in isolation procedures (Gustavs et al. 2017). Species of Elliptochloris are known to partner with mycobionts of diverse genera including Catillaria, Catolechia, Fuscidea, Micarea, Sticta, Stictis, Verrucaria, and the basidiolichen-forming Bryoclavula and Multiclavula (see Table 1). They also occur as endosymbionts of the marine anenome Anthopleura (Letsch et al. 2009).

Gloeocystis Nägeli - Taxa treated under this genus are unicellular green algae that form occasionally macroscopic colonies of ellipsoidal cells with a parietal chloroplast possessing a pyrenoid. Thick, colourless, often layered gelatinous sheaths surround the cells. Reports of Gloeocystis as photobiont of Cryptodiscus [Bryophagus] gloeocapsa and Epigloea bactrospora were cited by Ahmadjian (1967) and Tschermak-Woess $(1988 a)$. There is doubt as to whether Epigloea is lichenized (Kirk et al. 2001; not included in Lücking et al. (2017a)), although distinctly symbiotic contacts with living, unicellular green algae were illustrated by Jaag \& Thomas (1934) and Döbbler (1984).

According to Neustupa (2015), the algal genus Gloeocystis is highly polyphyletic, encompassing members of both Chlorophyceae and Trebouxiophyceae. The identities of the photobionts associated with the mycobionts mentioned above will therefore require further study.

Halofilum Darienko \& Pröschold - This is another genus that now accommodates taxa previously treated under Dilabifilum (Darienko \& Pröschold 2017). These algae consist of branched filaments with parietal chloroplasts containing pyrenoids; flagellated stages are unknown. The species $H$. ramosum occurs as photobiont of Hydropunctaria maura and Wahlenbergiella striatula (Verrucariaceae), as well as free-living (Darienko \& Pröschold 2017).

Heveochlorella J. Zhang et al. - Unicellular algae attributed to Heveochlorella have a prominent, somewhat lobed chloroplast with a central pyrenoid that is readily visible with light microscopy. TEM shows the pyrenoid surrounded by several irregular starch plates and penetrated centripetally by thylakoid-derived tubules that are lined with pyrenoglobuli (Fig. 2B). Cells reproduce by autospores, usually in low number (2-8) and not infrequently of unequal size within sporangia, at least in culture (Zhang et al. 2008; Ma et al. 2013; Sanders et al. 2016). Darienko \& Pröschold (2019) recently subsumed both Heveochlorella (Zhang et al. 2008) and the related Heterochlorella (Neustupa et al. 2009), which has not been reported from lichen symbioses, into the resurrected genus Jaagichlorella. These algae belong to the trebouxiophyceaen clade recently formalized as Watanabeales (Li et al. 2021).

The first indication that lichen symbionts belonged in this group was the report of Heveochlorella isolated as photobiont from one specimen of Sticta and two of Pseudocyphellaria from Taiwan (Dal Grande et al. 2014b). Soon thereafter, the 'trebouxioid' photobionts associated with foliicolous 
Gomphillaceae and Pilocarpaceae were also attributed to this genus (Sanders et al. 2016). More recently, a study of Sticta lichens worldwide reported Heveochlorella to be the photobiont of numerous specimens from New Zealand and Indian Ocean islands, including six identified species and many undetermined collections (Lindgren et al. 2020). In the opinion of Darienko \& Pröschold (2019), the algae encompassed by Jaagichlorella, though distributed worldwide, are rare taxa. While more surveys will be necessary to evaluate this view, a number of observations suggest that these algae might be in fact quite common and merely overlooked. We know, for example, that foliicolous lichens of the Gomphillaceae and Pilocarpaceae occur in abundance throughout much of the humid tropics (Santesson 1952; Lücking 2008), although it is not yet clear how consistently they harbour Heveochlorella (Jaagichlorella) photobionts. Recent sampling of the phyllosphere community in Asian tropical forests has revealed a major representation of Heveochlorella genotypes (Zhu et al. 2018), as well as several new species in related genera ( $\mathrm{Li}$ et al. 2020, 2021). Some of the most frequently detected OTUs in environmental surveys of marine habitats (Metz et al. 2019) were also attributed to Heveochlorella.

In many foliicolous lichens, dividing Heveochlorella photobionts may escape the lichenizing vegetative hyphae and proliferate among the spore-generating fungal structures, upon apothecia and within specialized conidiomata such as campylidia and hyphophores (Fig. 3B \& C). They can be dispersed from these structures, as are the fungal spores or diahyphae to which the algal cells may adhere (Fig. 3D-F). Once dispersed, they may become lichenized by the germinating fungal propagules, or divide to produce independent populations on the substratum (Sanders 2014; Sanders \& de los Ríos 2015). Co-dispersal and relichenization thereby provide Heveochlorella with abundant opportunities for exchange between lichenized and free-living populations.

Interfilum Chodat - This genus of aeroterrestrial charophytes (Streptophyta) includes taxa that form single, paired or sarcinoid packets of cells or grow filamentously, often closely resembling unrelated Chlorophyta, such as Desmococcus (Mikhailyuk et al. 2008). It is sister to clades of the widely distributed Klebsormidium (Rindi et al. 2011). Interfilum was reported by Voytsekhovich et al. (2011) as a secondary photobiont within the algal layer of Micarea and Placynthiella thalli collected in Ukraine, based on light microscopic examination of thalli and cultured isolates. The principal photobionts in those lichens were reported to be Elliptochloris and Radiococcus, respectively. As the charophytes are not otherwise known as lichen symbionts, and other algal genera were cited as the main photobionts within the thalli in question, further study of the reported associations is warranted.

\section{Jaagichlorella Reisigl - See Heveochlorella.}

Leptosira A. Borzì - This photobiont grows as unicells tightly wrapped by mycobiont hyphae or separated by copious sheath material free of the mycobiont; in agar culture, it produces short filaments (Tschermak-Woess 1953). Leptosira is a trebouxiophycean of uncertain placement, appearing in the vicinity of the Microthamniales clade in recent gene-based phylogenies (Lemieux et al. 2014; Neustupa 2015; Hallmann et al. 2016). According to Mattox \& Stewart (1984),
'Pleurastrum terrestre' (a synonym of Leptosira obovata, now L. terrestris; Friedl 1996) is so similar ultrastructurally to the genus Trebouxia that they could be combined in the same genus. Ahmadjian (1988) went one step further, opining that Trebouxia was merely the lichenized form of this taxon. However, the aforementioned gene-based cladograms do not show a close relationship between Leptosira and the Trebouxiales.

Leptosira terrestris, in lichen symbiosis with Vezdaea aestivalis, grows subcuticularly (Tschermak-Woess \& Poelt 1976), a distinction shared with the photobiont Cephaleuros. Leptosira is also among the very few photobiont genera (Phycopeltis and Cephaleuros are others) reported to produce zoospores in the lichenized state (Tschermak-Woess \& Poelt 1976).

Lithotrichon Darienko \& Pröschold - Another genus separated from the Dilabifilum (Ulvales) complex, Lithotrichon forms clustered cell packets as well as branching filaments and is distinguished from similar genera by SSU and ITS sequence data. The species L. pulchrum occurs as photobiont of the freshwater lichen Hydropunctaria rheitrophila (Darienko \& Pröschold 2017).

Myrmecia Printz - These spherical to pyriform unicells have a parietal chloroplast, without a pyrenoid, extending around most of the cell, with 2-4 broad lobes defined by deep notches. Cells proliferate via zoospores, aplanospores, or autospores (Ettl \& Gärtner 2014). Gene-based phylogenies consistently place Myrmecia in the Trebouxiales, sister to Trebouxia (Muggia et al. 2020) or to the Asterochloris + Vulcanochloris clade (Vančurová et al. 2015). Myrmecia occurs free-living as well as in lichen symbiosis. An aerophilic alga, originally described as Friedmannia from Negev Desert rocks, is now recognized as Myrmecia israelensis (Friedl 1995) and was recently reported as lichen photobiont (Thüs et al. 2011; Moya et al. 2018). Psora decipiens and a number of species in the Verrucariaceae are among the lichen-forming fungi known to partner with Myrmecia.

Nannochloris Naumann - The genus Nannochloris has encompassed simple, extremely tiny $(1.5-2 \mu \mathrm{m})$ chlorophyte algae that reproduce by binary division or autospores. Circumscription of the genus has been controversial, but molecular data indicate that most of the species belong in Chlorellales (Henley et al. 2004). Tschermak-Woess (1981) recognized Nannochloris normandinae as the photobiont partner of lichen-forming Normandina pulchella; in other works, Nannochloris has been mentioned more indirectly in the context of photobionts (e.g. Lohtander et al. 2003). However, Thüs et al. (2011) found only Diplosphaera as photobiont in the 10 Normandina thalli they examined and, more recently, Pröschold \& Darienko (2020) reduced Nannochloris normandinae to synonymy with Diplosphaera chodatii (Prasiolales). Thus, clear evidence of lichen photobionts belonging in Nannochloris appears to be lacking at present.

Neocystis F. Hindák - Members of this trebouxiophycean genus produce mucilaginous colonies of spherical to ellipsoidal or crescentshaped cells that reproduce by autospores (Neustupa 2015). Cultures assigned to Neocystis as well as other genera were recently reviewed with molecular sequence analyses, revealing considerable taxonomic redundancy assigned to only two closely related, 
genetically distinct but morphologically plastic species (Eliáš et al. 2013). An alga identified as Neocystis sp. was cited as 'additional photobiont' of Micarea misella, in thalli having Elliptochloris bilobata as principal photobiont (Voytsekhovich et al. 2011).

Paulbroadya Darienko \& Pröschold - This recently recognized clade in the Ulvales is distinguished by SSU-ITS sequences from other taxa previously treated under Dilabifilum (Darienko \& Pröschold 2017). The species Paulbroadya petersii occurs as photobiont of the marine intertidal lichen Wahlenbergiella mucosa (Darienko \& Pröschold 2017).

Phycopeltis Millardet - Members of this trentepohliaceous genus are most often seen as coppery orange discs a few $\mathrm{mm}$ in diameter on leaf surfaces in humid subtropical and tropical regions, with one or two species extending to cooler regions such as oceanic Europe (Rindi et al. 2004). Thallus discs consist of a monostromatic layer of closely appressed, bifurcating filaments (Fig. 6A). Unlike those of Cephaleuros, Phycopeltis thalli are supracuticular, non-pathogenic, and at least some species readily colonize other favourably displayed plant substrata besides leaves. Sporangia are usually borne erect on a very short stalk, and release quadriflagellate zoospores through a pore at the end opposite to the point of attachment. Gametangia are sessile and develop from intercalary compartments of the horizontal filament system in most species; gametes are biflagellate and isomorphic, and their fusion has been observed (Thompson \& Wujek 1997). The life cycle of Phycopeltis is believed to be haplodiplontic, with alternation of gametophytes and sporophytes that are isomorphic, rather than heteromorphic as in Cephaleuros and Stomatochroon (Thompson \& Wujek 1997). If this is the case, recognizing meiosporangia by the presence of tetrads might be the only means of distinguishing the phases phenotypically, but there do not appear to be such reports. Whether the gametophytes and sporophytes are equally susceptible to lichenization would be an interesting question to examine.

Although distinguishing Phycopeltis from Trentepohlia under current morphological concepts appears fairly straightforward, DNA sequence data show species of the two genera to be intertwined phylogenetically (Zhu et al. 2015, 2017; Grube et al. 2017a). Phycopeltis is particularly under-sampled at present. The morphological distinction between the two genera may also break down in the lichenized condition. Although Phycopeltis species can retain their placoid thallus characteristics when partnering with certain foliicolous mycobionts (Grube \& Lücking 2002), in other lichens the algal filaments may be broken up into individual cells indistinguishable from those of Trentepohlia (see fig. 9; Lücking 2008). Using TEM, Matthews et al. (1989) believed they could differentiate the two genera in such cases by features of the septal wall near plasmodesmata. It would be useful to test how well such traits correlate with molecular markers.

As widespread colonizers of the warm-temperate and tropical phyllosphere, species of Phycopeltis are important photobionts in foliicolous lichen communities, where they partner with diverse leaf-dwelling mycobionts including species of Arthonia, Chroodiscus, Mazosia, Opegrapha, Porina, Trichothelium, and supracuticular taxa of Strigulaceae, among others (Santesson 1952; Lücking 2008). Multiple Phycopeltis thalli may occur edge-to-edge within a single foliicolous lichen, as additional individuals are incorporated by the mycobiont's expanding prothallus (Sanders 2002). There are some reports of algal gametangia or sporangia being produced in the lichenized state, particularly in those taxa where the Phycopeltis thalli are sparsely covered by the mycobiont (Santesson 1952; Lücking 1994; Sanders 2002).

In at least one species of Phycopeltis (P. epiphyton), the highly degradation-resistant biopolymer sporopollenin was detected in the cell wall (Good \& Chapman 1978). Its presence in the walls of other photobionts (Coccomyxa and Elliptochloris) has been correlated with the absence of haustorial penetration by mycobionts (Honegger \& Brunner 1981; Brunner \& Honegger 1985). However, at least some strains of lichenized Phycopeltis may be deeply penetrated by mycobiont haustoria, such as those of Porina (Matthews et al. 1989).

Prasiola Meneghini - This trebouxiophycean seaweed of highlatitude supratidal zones is exceptional for its class in having a multicellular, macroscopic blade-like thallus. It is often abundant and readily visible both free-living and in symbiosis with mycobiont Mastodia tessellata (Verrucariaceae). Two or three distinct species of Prasiola appear to serve as photobiont to the bipolarly distributed Mastodia (Garrido-Benavent et al. 2017, 2018). There has been some discussion, on structural grounds, as to whether this fungal-algal partnership ought to be considered a true lichen (Lud et al. 2001; Kohlmeyer et al. 2004; Pérez-Ortega et al. 2010). There is no fungal cortex, nor does symbiosis substantially change algal thallus morphology; its anatomy, however, is significantly altered, as algal cells become well separated by a proliferation of encircling mycobiont hyphae (Kovačik \& Batista Pereira 2001; Lud et al. 2001). The symbiosis therefore entails considerably more structural transformation than that produced by the marine fungus Mycophycias upon its seaweed host Ascophyllum (Xu et al. 2008), or Turgidosculum upon Blidingia (Pérez-Ortega et al. 2018). From a phylogenetic perspective, it is worth noting that close relatives of both the mycobiont (Verrucariaceae) and the alga (Prasiolales) participate in symbioses that are unambiguously lichenic.

Pseudendoclonium Wille - These ulvalean algae have variably packet-forming to filamentous morphologies and may be differentiated into prostrate and erect filament systems. Darienko \& Pröschold (2017) moved into this genus a couple of photobionts previously treated under Dilabifilum, recognizing the photobiont of Arthopyrenia kelpii as Pseudendoclonium arthopyreniae, and the photobiont of Hydropunctaria maura as $P$. commune, which is also widespread as a free-living alga on intertidal rocks. Pseudendoclonium arthopyreniae has a pyrenoid surrounded by thick plates of starch and traversed by several narrow, thylakoid-derived membranes lacking pyrenoglobuli (Namba \& Nakayama 2021).

Pseudochlorella J. W. G. Lund - This unicellular genus of Chlorella-like algae is now placed in the Prasiolales. Molecular data support inclusion of the photobiont of at least one lichenforming fungus, Trapelia coarctata (Darienko et al. 2016). Other reports attribute to Pseudochlorella the photobionts of certain Micarea, Placynthiella and Stereocaulon species (see Tschermak-Woess 1988a; Voytsekhovich et al. 2011). However, molecular sequence studies have so far identified photobionts from Micarea as Coccomyxa and Elliptochloris, and those from the green algal layer of Stereocaulon as Asterochloris, Chloroidium and Vulcanochloris. 
Pseudococcomyxa Korshikov - Isolates identified as Pseudococcomyxa simplex have been reported as photobionts of a maritime Leproloma sp. (Watanabe et al. 1997) and also Micarea prasina (Voytsekhovich et al. 2011), based on light microscopy and culture studies. The genus Pseudococcomyxa has been distinguished morphologically from Coccomyxa by the polarized secretion of mucilage to form a cap at one end of the cell. However, Darienko et al. (2015) found this character to be culture-dependent, and the Pseudococcomyxa strains they analyzed phylogenetically appeared intermixed with those of Coccomyxa (see also Yahr et al. 2015). Isolates attributed to $P$. simplex in particular occurred in several distinct clades. Darienko et al. (2015) reassigned all these strains to Coccomyxa. While lichen photobiont isolates attributed to Pseudococcomyxa remain to be examined, support for distinction of the genus from Coccomyxa now appears to be lacking.

Pseudostichococcus L. Moewus - Morphologically similar to Stichococcus, this genus was recently revised with molecular data (Pröschold \& Darienko 2020). It currently includes the photobiont partner of Neocatapyrenium rhizinosum (Hodač et al. 2016) in the Verrucariaceae.

Pseudotrebouxia P. A. Archibald - See Trebouxia.

Radiococcus Schmidle - Species of this genus have been reported to occur as principal photobiont in thalli of two species of Placynthiella (P. icmalea and P. uliginosa) from the Ukraine (Voytsekhovich et al. 2011). Corroboration with DNA sequence data is needed, particularly since diverse, unrelated taxa have been repeatedly ascribed to this genus in the past (Wolf et al. 2003). According to a recent taxonomic treatment, Radiococcaceae and Radiococcus belong in the order Sphaeropleales of the Chlorophyceae (Neustupa 2015), although these names are still being applied to taxa falling in other groups, such as the Trebouxiophyceae (e.g. Metz et al. 2019).

Stichococcus Nägeli s. lat. - In its broad sense, Stichococcus (Prasiolales) has encompassed smallish unicellular to filamentous algae of notably labile morphology, the most commonly recognized form represented by short-cylindrical cells. The chloroplast is parietal, often extending to no more than half of the cell circumference, not markedly lobed, with or without a pyrenoid. Culture conditions appear to have a significant effect on cell form. The straight or slightly curved, rod-shaped cells may separate or remain together after division to form very short filaments or swell to more spherical shapes, and may or may not produce a surrounding gelatinous sheath (Ettl \& Gärtner 2014). Quite a number of lichen photobionts have been ascribed to Stichococcus, but as their diversity is studied at the molecular level, these taxa are being placed in segregate genera or other prasiolalean clades. Some seven to nine clades have now been recognized within Stichococcus s. lat. (Hodač et al. 2016; Pröschold \& Darienko 2020). All Stichococcus-like photobionts examined in a study of the Verrucariaceae by Thüs et al. (2011), were shown to belong in Diplosphaera. Others now appear to fall within Pseudostichococcus, Deuterostichococcus or Tritostichococcus (Pröschold \& Darienko 2020). It is not yet clear whether Stichococcus in the restricted sense (near to type species $S$. bacillaris) includes lichen photobionts.
Symbiochloris Škaloud et al. - Formally described by Škaloud et al. (2016), the genus corresponds to a distinct clade of Dictyochloropsis s. lat. previously recognized by Dal Grande et al. (2014b). Symbiochloris is currently thought to include all lichen photobionts previously included in Dictyochloropsis, as well as some free-living taxa. Principal mycobiont partner genera are Lobaria, Pseudocyphellaria, Sticta and their recent segregates Crocodia, Dendriscosticta and Ricasolia, all members of the Lobariaceae. Other lichens reported harbouring Symbiochloris photobionts include species of Biatora, Brigantiaea, Chaenotheca, Megalospora and Phlyctis.

The net-like chloroplast of Symbiochloris, similar to that of Dictyochloropsis, has reticulations that vary in form, thickness and orientation according to species and developmental stage (Škaloud et al. 2005, 2016). Lichenized populations reproduce by aplanospores, but zoospore production may be observed in isolated culture. Cells of free-living populations often attain much larger sizes and their surfaces may be covered with scales (Tschermak-Woess 1995).

Trebouxia Puymaly - The principal crop of the alga-farming fungi, unicellular Trebouxia is thought to include the photobionts chosen by the largest proportion (nearly half) of known mycobiont species. Together with the closely related Asterochloris, Trebouxia is chlorobiont of most Lecanorales and Teloschistales, as well as many other taxa of the other species-rich lecanoromycetid orders (Miadlikowska et al. 2014). Species of Trebouxia are spherical or occasionally ellipsoidal unicells with a variously lobed, axial chloroplast that fills much of the cell and bears a prominent pyrenoid (Fig. 2A \& C). There is considerable diversity of pyrenoid ultrastructure within the genus, involving differences in the morphology of penetrating membranes and the distribution of starch deposits and pyrenoglobuli, when present (Peveling 1968, 1969; Fisher \& Lang 1971; Friedl 1989). $\mathrm{CO}_{2}$-fixing Rubisco is concentrated in the pyrenoids, which in some instances also comprise additional, smaller, satellite substructures within the chloroplast (Ascaso et al. 1995). Although pyrenoid types do not correspond precisely to the Trebouxia clades supported in molecular sequence analyses, and several are strikingly convergent with pyrenoids of distantly related algae, they can nonetheless be useful in distinguishing certain groupings of taxa at close range (Friedl 1989; but see also Muggia et al. (2010)). Some 30 species of Trebouxia, distributed among four major clades, are currently recognized. However, this figure is believed to grossly underestimate the true genetic diversity present in the genus (Leavitt et al. 2015; Muggia et al. 2020). The boundaries among the formally described species remain largely unresolved, since much of the genetic diversity uncovered in recent studies is not fully congruent with the phenotypically defined taxa. Muggia et al. (2017) postulated that the application of a phylogenetic species concept would at least triple the number of species currently recognized in Trebouxia.

Two different groups were long distinguished within Trebouxia s. lat. (Ahmadjian 1960), which was previously known as Cystococcus. Archibald (1975) recognized two genera, Trebouxia and Pseudotrebouxia, based on differences in cell division which were judged sufficient to separate them into two distinct orders. However, Gärtner (1985) and Tschermak-Woess (1989) found Archibald's subdivision untenable and reunited the genus, while acknowledging that differences in cell division were present. Tschermak- 
Woess (1989) distinguished two subgenera: Trebouxia (corresponding roughly to Pseudotrebouxia), which forms aplanospores (or zoospores in culture) and also autospores, and Eleutherococcus (later Asterochloris), which produces aplanospores/zoospores but not autospores. Autospores are distinguishable from aplanospores in that they are produced in lower numbers and are tightly appressed together within the sporangium such that their walls form angular junctions between them (Tschermak-Woess 1989). Another difference is the position of the chloroplast during cell division, which remains more or less central in Trebouxia but becomes parietal and flattened in Asterochloris (Ahmadjian 1960; Tschermak-Woess 1989). Molecular data firmly distinguish the two clades, which have been formally recognized as distinct genera for the past decade (Škaloud \& Peksa 2010).

As a lichen symbiont, Trebouxia is abundant in a great diversity of habitats worldwide. It is said to be infrequently reported in the free-living state, although researchers who sample substrata with microscopy have often found it (Tschermak-Woess 1978; Bubrick et al. 1984; Mukhtar et al. 1994; Sanders 2005; Handa et al. 2007; Uher 2008; Neustupa \& Štifterová 2013), with the notable exception of Degelius (1964). Clearly, the germinating spores of trebouxiophilic mycobionts manage to obtain it, often without needing to produce an extensive mycelium (Werner 1931; Clayden 1998). Recent environmental sequencing studies have found Trebouxia on a variety of surfaces (Darienko et al. 2013; Hallmann et al. 2013, 2016; Yung et al. 2014) and well represented in soil, fresh water and even marine environments (Metz et al. 2019), although one cannot be certain that the detected sequences represent free-living individuals. By contrast, two other principal lichen photobiont genera, Trentepohlia and Nostoc, are uncontroversially well known in the free-living state. The comparison may not be fair, however, because Trentepohlia and Nostoc both form easily recognized macrocolonies (bright orange tufts and distinctive gelatinous globs, respectively) whereas Trebouxia cannot be distinguished without a microscope and some degree of effort. In any case, a shadow of doubt still seems to haunt the status of free-living Trebouxia populations, to judge from the cautious wording in even quite recent literature (e.g. Friedl \& Büdel 2008). Although he never claimed to have searched for it in nature, Ahmadjian (1988, 1993, 2001, 2002) repeatedly affirmed that Trebouxia existed only in highly coevolved symbiosis with lichen fungi and did not occur free-living. Yet he acknowledged that aposymbiotic populations of Trebouxia could appear in nature. He even proposed, as have others, that they arose from the breakdown of lichenized propagules, such as soredia and isidia, that reach microhabitats unsuitable for the partners to develop symbiotically (Ahmadjian 1988). Ahmadjian asserted, however, that such populations were not truly freeliving, except in a 'secondary sense'. Apparently, he meant that they were ephemeral rather than stably established, but stable or not, aposymbiotic populations of Trebouxia are likely to be significant. Like other micro-organisms, many algae take advantage of ephemeral resources and transiently favourable microenvironments, then complete their life cycles with sexual reproduction when conditions deteriorate. Some then survive as resistant spores; others may escape adversity by entering into lichen symbioses. Within a lichen thallus, an algal population may be perpetuated for many years, yet continually disperse via soredia, isidia, lichenized fragments and other propagules that can seed new free-living populations. This has been characterized as photobiont 'escape' from the lichen fungus (Werth 2010). It may be equally valid to view relichenization as photobiont escape from conditions that aposymbiotic populations might not long endure.

Although stages of flagellar development within a lichen thallus were reported (Slocum et al. 1980), authors have expressed scepticism that Trebouxia could produce motile or sexual cells in the symbiotic state (Tschermak-Woess 1989), where all algal cells are held by one or more appressorial hyphae (Honegger 1990). In aposymbiotic culture, by contrast, the production and release of Trebouxia zoids are well documented (Ahmadjian 1960, 1967; TschermakWoess 1989; Takeshita 2001). The huge genetic diversity present (Muggia et al. 2020) and its structure within populations (Kroken \& Taylor 2000) suggest that Trebouxia is reproducing sexually, but virtually nothing is known about how or when the sexual cycle proceeds in nature. Although it is often said that sexual reproduction has not been observed in this genus, both Warén (1920) and Ahmadjian (1960) reported and illustrated the fusion of flagellate isogametes in Trebouxia cultures. However, Ahmadjian (1988, 2001) believed that these features were vestiges of the alga's free-living ancestry that no longer play any role in their present life histories. Further investigation of aposymbiotic populations is needed, since considerable indirect evidence suggests that they may reveal key events in the Trebouxia life cycle.

Trentepohlia C. Martius - The filamentous taxa currently treated under this cosmopolitan genus are among the most familiar of subaerial algae, often forming readily visible yellowish orange tufts on bark, rocks and other substrata in a wide variety of environments. They are also among the phycobionts chosen by the most diverse lichen-forming ascomycetes, including members of the Arthoniomycetes, Coniocybomycetes, Dothidiomycetes, Eurotiomycetes (Pyrenulales) and ostropalean Lecanoromycetes such as the species-rich Graphidaceae. Members of the order Trentepohliales and its sole family Trentepohliaceae present a distinctive combination of features: phragmoplastic cell division with plasmodesmata (otherwise characteristic of charophycean algae), a uniquely structured flagellar apparatus, peculiar sporangiophores, and distinctive orange pigmentation. Consequently, widely divergent interpretations of their phylogenetic affinities have been proposed, with some authors even placing the group in a separate class of its own (van den Hoek et al. 1995). However, rDNA sequence data firmly place the subaerial Trentepohliales among orders of mainly marine taxa within the Ulvophyceae (LópezBautista \& Chapman 2003; Leliaert et al. 2012).

Among the taxa currently treated under Trentepohlia, a number of genera were described to accommodate the morphological diversity represented, most recently Printzina (Thompson \& Wujek 1992). However, DNA sequence analyses have so far shown that the phenotypic similarities recognized are unreliable indicators of phylogenetic affinity (LópezBautista et al. 2006; Rindi et al. 2009). This also applies to some of the morphological traits currently used to distinguish Trentepohlia species from those of Phycopeltis. Free-living and lichenized isolates of Trentepohlia occur intermixed in gene-based phylogenies (Nelsen et al. 2011; Hametner et al. 
2014a, b; Kosecka et al. 2020). Due to its visible and widespread presence in the free-living state, Trentepohlia is an excellent subject for studying the relationship between lichenized and aposymbiotic populations in nature (Fig. 1A-C). So far, however, the genus has been the focus of relatively few modern phylogenetic studies, despite its visibility and primary importance in lichen symbioses.

The pigments characteristic of the Trentepohliaceae, called 'haematochrome' in the older literature, are carotenoids that occur abundantly as lipidic globules in the cytoplasm. Some authors have attributed the colour to astaxanthin (Thompson \& Wujek 1997; Grube et al. 2017a), a deep red carotenoid known from other chlorophytes such as Haematococcus and the snow alga Chlamydomonas nivalis. However, analyses of Trentepohlia haematochrome show principally beta-carotenes (Czeczuga \& Maximov 1996; Mukherjee et al. 2010; Kharkongor \& Ramanujam 2015; Chen et al. 2016). Located outside the plastids, these secondary carotenoids do not participate in photosynthetic light-harvesting but are hypothesized to filter excess light and suppress any damaging reactive oxygen species thereby generated (Solovchenko 2013). This may contribute to the visible success of Trentepohlia in colonizing exposed substrata in diverse environments.

The sporangia of Trentepohlia are themselves units of dispersal, easily detached when mature and vectored by wind, rain or insects. They then initiate a second round of shorterdistance dispersal by releasing quadriflagellate zoospores (Thompson \& Wujek 1997). Trentepohlia also produces putative gametangia that are morphologically distinct from sporangia. However, the biflagellate zoïds released have most often been observed germinating as spores rather than fusing as gametes (Rindi \& Guiry 2002).

Cellular contacts between mycobionts and their trentepohliaceous photobionts often appear to be superficial. However, most of these lichens, when carefully examined microscopically, reveal haustorial penetration, often deeply into the algal cells (Tschermak 1941a; Withrow \& Ahmadjian 1983; Matthews et al. 1989; but see Meier \& Chapman 1983).

Trentepohlia photobionts have been occasionally reported to grow out from the algal layer and emerge as free filaments projecting from the lichen thallus or thalline apothecial margin (Zahlbruckner 1907: p. 126; McGee 2002). In one case, such a filament was seen bearing a sporangium (Tschermak 1941a: p. 289). However, some authors have expressed scepticism about this interpretation, suggesting that epiphytic Trentepohlia might instead develop upon, and then grow into, an already formed thallus (Henssen \& Jahns 1974: p. 196). More detailed observations are clearly required, but either explanation could represent another potentially significant mechanism by which exchange may occur between lichenized and free-living populations.

Tritostichococcus Pröschold \& Darienko - This recent segregate of Stichococcus s. lat. (Pröschold \& Darienko 2020) includes the Stichococcus-like photobionts that associate with Chaenotheca, a genus of lichen-forming fungi that partner with a remarkably broad spectrum of photobionts (Tibell 2001).

Trochiscia Kützing - This genus of unicellar algae is characterized by an often-thick cell wall with spine- or wart-like projections, an irregularly stellate chloroplast, and two forms of endogenous spore production, resulting in hundreds of small cylindrical autospores or just two rounded endospores (Tschermak 1941b). Trochiscia currently appears to be placed among the Chlorophyceae, in or near Sphaeropleales (Fučíková et al. 2019). It was identified as photobiont of Polyblastia amota and P. hyperborea (Tschermak 1941b; Ahmadjian 1967) in the Verrucariaceae, but those reports appear to be in doubt (Ettl \& Gärtner 2014) and further studies are needed. Trochiscia was not among the photobionts detected in the survey by Thüs et al. (2011) of the algal partners of Verrucariaceae.

Vulcanochloris Vancurová et al. - This newest addition to the Trebouxia family encompasses three recently described species with a distinctive, highly dissected chloroplast structure, and molecular sequences that place them as sister to Asterochloris (Vančurová et al. 2015). They are known mainly as principal photobionts from some thalli of Stereocaulon vesuvianum in the Canary Islands, although there is also a very recent report of Vulcanochloris from a Stereocaulon thallus collected in highland Bolivia (Kosecka et al. 2021). Most other Stereocaulon lineages investigated to date appear to associate with Asterochloris or Chloroidium (Vančurová et al. 2018). Vulcanochloris has also been recently reported as a minority photobiont in thalli of Ramalina farinacea (Moya et al. 2017).

\section{Stramenopila (Heterokontae)}

Heterococcus Chodat - The yellow-green (xanthophyte) algae lack fucoxanthin, the golden brownish plastidial carotenoid otherwise characteristic of the photosynthetic stramenopiles. The absence of fucoxanthin makes them rather easy to confuse with green algae. Their zoospores, however, will have the characteristic stramenopilous flagellum bearing stiff, hollow, tripartite appendages (mastigonemes). Heterococcus forms irregular filaments and/or cell clusters when isolated into culture (Zeitler 1954). Molecular sequences support the light microscope identification of Heterococcus as photobiont in thalli of three species of Verrucariaceae (Hydropunctaria rheitrophila, Verrucaria funckii and $V$. hydrela) that are each in separate clades and not closely related to one another (Thüs et al. 2011). Another xanthophyte, Heterothrix (now Xanthonema; Silva 1979) was identified via light microscopy as photobiont of Staurothele clopimoides (Pereira Riquelme 1992) but that interesting report requires corroboration.

Petroderma Kuckuck - Petroderma maculiforme is a small crustose brown alga (Phaeophyceae) found on rocks in the lower intertidal zone of western North America and Europe. In San Francisco Bay, it is particularly common on discarded plastic (Sanders et al. 2004). The alga is a disc of tightly branched, radiating horizontal filaments, rather similar in morphology to the chlorophyte Phycopeltis but with a dense carpet of short, erect filaments arising proximally from the horizontal system. In the free-living state, these erect filaments may bear unilocular and/or plurilocular sporangia (zoidangia) terminally (Fritsch 1945). Chloroplasts typically possess one or several large pyrenoids that are prominent in electron micrographs (Fig. 2D) but not readily visible with light microscopy. The pyrenoids are traversed by branching tubules arising from invagination of the plastidial boundary membranes (rather than 
thylakoids, as in Trebouxia and Heveochlorella); the position of the pyrenoid may be laminar, protruding to exserted, or enfolded by chloroplast lobes (Sanders et al. 2005). The alga was first brought to the attention of lichenologists by a footnote in a phycology dissertation (Wynne 1969) that reported it in symbiosis with a Verrucaria species on intertidal rocks in northern California. The lichen was not studied further until Moe (1997) re-collected it and formally described the fungal symbiont as Verrucaria tavaresiae (now Wahlenbergiella tavaresiae; Gueidan et al. 2011). When lichenized, the Petroderma filaments are separated by fungal tissue, into which they grow and branch downwards rather than upwards as in the freeliving condition (Sanders et al. 2004). Petroderma is the only member of the Phaeophyceae known to enter into lichen symbiosis. However, certain larger brown seaweeds, such as Ascophyllum, have intimate, mutualistic associations with verrucariacean fungi (Garbary \& London 1995; Garbary \& MacDonald 1995) that are generally not considered to be lichens on structural grounds, since the fungus grows within algal tissues as a conventional mycelium (Hawksworth 1988).

Table 1. Taxonomically grouped list of photobiont genera and mycobionts reported in association with them. The family names of the mycobionts are included in places where emphasis might be useful. id = procedures used in the study to identify the photobiont. LM=light microscopy, TEM=transmission electron microscopy. See table 1 in Tschermak-Woess (1988a) for a comprehensive list of photobiont reports prior to 1988. Taxon names follow those used in the original articles.

\begin{tabular}{|c|c|c|}
\hline Alga & Fungal symbionts & References \& comments \\
\hline \multicolumn{3}{|c|}{ Domain Bacteria, Phylum Cyanobacteria } \\
\hline [Brasilonema] sp. & $?$ & $\begin{array}{l}\text { Villanueva et al. (2018). Lichen not identified; need } \\
\text { evidence that algal isolate is lichen photobiont. }\end{array}$ \\
\hline Calothrix and Dichothrix & Lichina spp., Placynthium nigrum & see Tschermak-Woess (1988a) \\
\hline Chroococcidiopsis sp. & $\begin{array}{l}\text { Anema nummularium, Peccania cerebriformis, } \\
\text { Psorotichia columnaris, Gonohymenia sp. }\end{array}$ & Büdel \& Henssen (1983); Büdel (1985). id: LM, culture. \\
\hline Chroococcidiopsis sp. & Peltula spp. and 'other cyanolichen genera' & $\begin{array}{l}\text { Büdel (1999). Unpublished 16S rDNA data of B. Büdel } \\
\text { \& T. Friedl. cited. }\end{array}$ \\
\hline Chroococcidiopsis sp. & Anema nummularium, Peltula euploca, Thyrea pulvinata & Fewer et al. (2002) \\
\hline [Chroococcidiopsis] sp. & $?$ & $\begin{array}{l}\text { Villanueva et al. (2018). Lichen not identified; need } \\
\text { evidence that algal isolate is a lichen photobiont. }\end{array}$ \\
\hline $\begin{array}{l}\text { Chroococcidiopsis/ } \\
\text { Chroococcidiopsidales }\end{array}$ & $\begin{array}{l}\text { Peltula bolanderi, P. clavata, P. euploca, P. impressa, } \\
\text { P. obscurans, P. placodizans }\end{array}$ & Võ (2016) \\
\hline Gloeocapsa sp. & $\begin{array}{l}\text { Species of Anema, Edwardiella, Gonohymenia, Heppia, } \\
\text { Jenmania, Peccania, Phylliscum, Psorotichia, Pyrenopsis, } \\
\text { Synalissa and Thyrea; cephalodia of Amygdalaria and } \\
\text { Stereocaulon spp. }\end{array}$ & $\begin{array}{l}\text { Numerous LM reports summarized by } \\
\text { Tschermak-Woess (1988a). Friedl \& Büdel (2008); } \\
\text { Brodo et al. (2001). id: LM. }\end{array}$ \\
\hline Hyella sp. & Collemopsidium sp. & see Ahmadjian (1967). id: LM. \\
\hline Hyphomorpha sp. & Spilonema dendroides, S. schmidtii & Henssen (1981). id: LM. \\
\hline Myxosarcina sp. & Peltula euploca & Friedl \& Büdel (2008) \\
\hline Nostoc sp. & $\begin{array}{l}\text { Nephroma resupinatum, Peltigera britannica, } P \text {. canina, } \\
\text { P. membranacea; cephalodia of Peltigera aphthosa, } P \text {. } \\
\text { venosa }\end{array}$ & $\begin{array}{l}\text { Paulsrud et al. (2000, 2001). High genetic specificity, } \\
\text { also for cephalodia formation, overrules geography. }\end{array}$ \\
\hline Nostoc sp. & Collema multipartitum & Oksanen et al. (2002) \\
\hline Nostoc sp. & Nephroma, numerous spp. & Lohtander et al. (2003) \\
\hline Nostoc sp. & $\begin{array}{l}\text { Leptogium puberulum, Massalongia carnosa, Placopsis } \\
\text { contortuplicata, P. parellina, Psoroma cinnamomeum }\end{array}$ & $\begin{array}{l}\text { Wirtz et al. (2003). Maritime Antarctica; two main } \\
\text { clades that also include free-living Nostoc. }\end{array}$ \\
\hline Nostoc sp. & $\begin{array}{l}\text { Collema crispum, Leptogium gelatinosum, Lobaria } \\
\text { amplissima, L. hallii, Massalongia carnosa, Nephroma } \\
\text { bellum, N. helveticum, Pannaria conoplea, } \\
\text { Peltigera canina, P. degenii, P. didactyla, P. horizontalis, } \\
\text { P. lepidophora, P. membranacea, P. neopolydactyla, } \\
\text { P. rufescens, Sticta beauvoisii, S. fuliginosa; cephalodia } \\
\text { of Peltigera aphthosa }\end{array}$ & O’Brien et al. (2005) \\
\hline Nostoc sp. & Pseudocyphellaria crocata, (=)P. neglecta, (=)P. perpetua & Summerfield \& Eaton-Rye (2006) \\
\hline Nostoc sp. & $\begin{array}{l}\text { Pannaria andina, P. araneosa, P. athroophila, } \\
\text { P. conoplea, } P \text {. durietzii, P. elixii, P. euphylla, P. farinosa, } \\
\text { P. fulvescens, P. isabellina, P. lobulifera, P. mosenii, } \\
\text { P. obscura, P. pallida, P. patagonica, P. rubiginella, } \\
\text { P. rubiginosa, P. sphinctrina, P. tavaresii }\end{array}$ & Elvebakk et al. (2008) \\
\hline Nostoc sp. & Degelia atlantica, D. plumbea & Otálora et al. (2013) \\
\hline
\end{tabular}


Table 1. (Continued)

\begin{tabular}{|c|c|c|}
\hline Alga & Fungal symbionts & References \& comments \\
\hline Nostoc sp. & Polychidium muscicola & Jayalal et al. (2012) \\
\hline Nostoc sp. & $\begin{array}{l}\text { Species of Fuscopannaria, Kroswia, Pannaria, } \\
\text { Parmeliella and Physma }\end{array}$ & $\begin{array}{l}\text { Magain \& Sérusiaux (2014). Homoiomerous } \\
\text { (gelatinous) vs stratified anatomy correlated with } \\
\text { Nostoc strain, not fungal family, across Pannariaceae } \\
\text { and Collemataceae. }\end{array}$ \\
\hline Nostoc sp. & Leptogium lichenoides, Peltigera islandica, P. ponojensis & Joneson \& O’Brien (2017) \\
\hline Nostoc sp. & Peltigera sections Peltigera and Retifoviatae & Magain et al. (2018) \\
\hline Nostoc sp. & Pectenia plumbea & Cardós et al. (2019) \\
\hline Rhizonema andinum & $\begin{array}{l}\text { Cora arachnodavidea, C. barbulata, C. bovei, } \\
\text { C. dewisanti, C. dewisanti-mexicana, C. elephas, } \\
\text { C. hawksworthiana, C. hochesuordensis, C. pseudobovei, } \\
\text { Cora sp.; cephalodia of Stereocaulon fronduliferum }\end{array}$ & Dal Forno et al. (2020) \\
\hline
\end{tabular}

R. interruptum lineage Coccocarpia filiformis, C. palmicola, C. stellata, Cora applanata, C. aspera, C. auriculeslia, C. canari, C. ciferrii, C. crispoleslia, C. galapagoensis, C. hymenocarpa, C. melvinii, C. paraciferrii, C. reticulifera, C. smaragdina, C. soredavidia, C. squamiformis, C. strigosa, C. suturifera, C. terrestris, C. viliewoa, Cora sp. Cyphellostereum sp., Dictyonema aeruginosum, D. barbatum, D. darwinianum, D. hernandezii, D. interruptum [= D. coppinsii], D. phyllogenum, D. sericeum, D. schenkianum, Dictyonema sp.; cephalodia of Stereocaulon ramulosum

\begin{tabular}{|c|c|c|}
\hline R. neotropicum & $\begin{array}{l}\text { Acantholichen pannarioides, Coccocarpia palmicola, } \\
\text { Cora gigantea, C. leslactuca, C. rubrosanguinea, Corella } \\
\text { sp., Dictyonema sp. }\end{array}$ & Dal Forno et al. (2020) \\
\hline Rhizonema sp. & $\begin{array}{l}\text { Acantholichen pannarioides, Coccocarpia filiformis, } \\
\text { C. palmicola, C. stellata, Dictyonema aeruginosulum, } \\
\text { D. coppinsii, D. glabratum, D. hernandezii, } \\
\text { D. phyllogenum, D. schenkianum, D. sericeum, } \\
\text { Coccocarpia; cephalodia of Stereocaulon fronduliferum } \\
\text { and S. ramulosum }\end{array}$ & $\begin{array}{l}\text { Lücking et al. (2009). Shows photobiont more closely } \\
\text { related to Nostoc clade than to Scytonema s. str. } \\
\text { Lücking et al. (2014): formal description of genus } \\
\text { Rhizonema. }\end{array}$ \\
\hline Rhizonema sp. & Athelia andina, Cyphellostereum pusiolum & $\begin{array}{l}\text { Oberwinkler (2012). Mycobiont also associates with } \\
\text { green photobiont. }\end{array}$ \\
\hline Rhizonema sp. & Athelia phycophila & $\begin{array}{l}\text { Jülich (1972). Reported as Scytonema. Athelia poeltii } \\
\text { also said to associate with filamentous cyanobacteria; } \\
\text { Jülich (1978). }\end{array}$ \\
\hline Rhizonema sp. & $\begin{array}{l}\text { Coccocarpia palmicola, Erioderma pedicellatum, } \\
\text { E. sorediatum, Leptogidium sp., Lichinodium sp., } \\
\text { Moelleropsis nebulosa, Parmeliella parvula }\end{array}$ & $\begin{array}{l}\text { Cornejo \& Scheidegger (2016); Cornejo et al. (2016). } \\
\text { Boreal env. (Newfoundland). Also symbiotic among } \\
\text { liverwort Frullania asagrayana. }\end{array}$ \\
\hline Rhizonema sp. & Lichinodium ahlneri, L. sirosiphoideum (Leotiomycetes!) & Prieto et al. (2019) \\
\hline Rhizonema sp. & Dictyonema moorei & Masumoto (2020) \\
\hline Rivularia sp. & Lichina confinis, L. pygmaea & Ortiz-Álvarez et al. (2015) \\
\hline Scytonema sp. & Pyrenothrix nigra & Tschermak-Woess et al. (1983). id: LM \& TEM. \\
\hline Scytonema sp. & $\begin{array}{l}\text { Species of Heppia, Lichinodium, Thermutis and } \\
\text { Zahlbrucknerella }\end{array}$ & $\begin{array}{l}\text { Henssen (1994). DNA sequence data needed. Might be } \\
\text { Rhizonema, but see Võ (2016) concerning Heppia. }\end{array}$ \\
\hline Scytonema sp. & Heppia lutosa & $\begin{array}{l}\text { Võ (2016). A 16s rRNA sequence suggests true } \\
\text { Scytonema, not Rhizonema. }\end{array}$ \\
\hline Stigonema sp. & Species of Ephebe and Spilonema & Henssen \& Jahns (1974). id: LM. \\
\hline Stigonema sp. & Cephalodia of Stereocaulon & Lavoie et al. (2020) \\
\hline Tolypothrix sp. & Thermutopsis sp. & Henssen (1990) \\
\hline cf. Tolypothrix & Cephalodia of Placopsis perrugosa and P. stenophylla & Raggio et al. (2012) \\
\hline \multicolumn{3}{|c|}{$\begin{array}{l}\text { Domain Eukarya, Eukaryote supergroup Archaeplastida, Kingdom Plantae, Division Chlorophyta } \\
\text { Class Trebouxiophyceae, Order Chlorellales }\end{array}$} \\
\hline Auxenochlorella & Psoroglaena stigonemoides & Thüs et al. (2011) \\
\hline Near A. protothecoides & Psoroglaena stigonemoides & Nyati et al. (2007). Strain P-1015. \\
\hline
\end{tabular}


Table 1. (Continued)

\begin{tabular}{|c|c|c|}
\hline Alga & Fungal symbionts & References \& comments \\
\hline Near Chlorella sorokiniana & Porpidia crustulata & Li et al. (2013) \\
\hline Nannochloris normandinae & Normandina pulchella & $\begin{array}{l}\text { Tschermak-Woess }(1988 a) \text {. Pröschold \& Darienko } \\
\text { (2020) synonymize N. normandinae with Diplosphaera } \\
\text { chodatii. }\end{array}$ \\
\hline \multicolumn{3}{|c|}{ Class Trebouxiophyceae, Order Prasiolales } \\
\hline $\begin{array}{l}\text { Deuterostichococcus allas and } D . \\
\text { antarcticus }\end{array}$ & Placopsis antarctica, P. contortuplicata & $\begin{array}{l}\text { Beck et al. (2019). Reclassified by Pröschold \& } \\
\text { Darienko (2020). }\end{array}$ \\
\hline D. deasonii & Staurothele clopima & Hodač et al. (2016); Pröschold \& Darienko (2020). \\
\hline Diplosphaera chodatii & Dermatocarpon luridum var. luridum & Fontaine et al. (2012); Doering et al. (2020). \\
\hline Diplosphaera sp. & $\begin{array}{l}\text { Agonimia koreana, A. opuntiella, A. repleta, A. tristicula, } \\
\text { Bagliettoa parmigera, Catapyrenium cinereum, } \\
\text { C. daedaleum, Dermatocarpon luridum, D. miniatum, } \\
\text { Endocarpon adscendens, E. diffractellum, E. pallidulum, } \\
\text { E. pusillum, Flakea papillata, Neocatapyrenium } \\
\text { rhizinosum, Normandina acroglypta, N. pulchella, } \\
\text { Placidiopsis cartilaginea, Placopyrenium bucekii, } \\
\text { Polyblastia cupularis, P. viridescens, Staurothele } \\
\text { areolata, S. clopima, S. clopimoides, S. drummondii, } \\
\text { S. fissa, S. frustulenta, Verrucaria elaeina, V. hochstetteri, } \\
\text { V. nigrescens, V. pratermissa, V. rupestris (Verrucariaceae) }\end{array}$ & $\begin{array}{l}\text { Thüs et al. (2011). Morphologically similar to } \\
\text { Stichococcus, but not close to type sp. S. bacillaris. }\end{array}$ \\
\hline Diplosphaera sp. & Ramalina farinacea & Moya et al. (2017). Minority photobiont. \\
\hline Prasiola borealis & Mastodia tessellata & $\begin{array}{l}\text { Moniz et al. (2012). Authors refer to symbiotic form as } \\
\text { lichenized. Stipe section shows photobiont } \\
\text { well-embedded in fungal tissue. }\end{array}$ \\
\hline$P$. borealis and one undescribed sp. & Mastodia tessellata & Pérez-Ortega et al. (2012); Garrido-Benavent et al. (2017). \\
\hline P. delicata & Mastodia tessellata & Moniz et al. (2014); Garrido-Benavent et al. (2018). \\
\hline Prasiola sp. & Mastodia tessellata & Thüs et al. (2011) \\
\hline Pseudochlorella pyrenoidosa & Micarea assimilata & Zeitler (1954); Tschermak-Woess (1988a). \\
\hline P. signiensis & Trapelia coarctata & Darienko et al. (2016) \\
\hline Pseudochlorella sp. & Stereocaulon strictum & $\begin{array}{l}\text { Brunner \& Honegger (1985). Pyrenoid ultrastructure } \\
\text { suggests this strain might be Chloroidium, as indicated } \\
\text { by DNA sequences from other Stereocaulon } \\
\text { photobionts. }\end{array}$ \\
\hline Pseudochlorella sp. & Placynthiella dasaea & Voytsekhovich et al. (2011). id: LM, culture. \\
\hline Pseudochlorella sp. & Umbilicaria antarctica & $\begin{array}{l}\text { Park et al. (2015). In some thallus samples, along with } \\
\text { Trebouxia. Status as photobiont needs corroboration. }\end{array}$ \\
\hline Pseudostichococcus clade & Neocatapyrenium rhizinosum & Hodač et al. (2016); Pröschold \& Darienko (2020). \\
\hline Tritostichococcus coniocybes & Chaenotheca sp. & Pröschold \& Darienko (2020) \\
\hline \multicolumn{3}{|c|}{ Class Trebouxiophyceae, Order Trebouxiales } \\
\hline Asterochloris antarctica & Cladonia sp. & Kim et al. (2020) \\
\hline Asterochloris clade I1 & $\begin{array}{l}\text { Cladonia corymbescens, C. furcata, C. pyxidata, } \\
\text { C. rangiferina }\end{array}$ & Řidká et al. (2014) \\
\hline Asterochloris clade 12 & Cladonia furcata & Řidká et al. (2014) \\
\hline Asterochloris clade II & Cladonia subtenuis & Yahr et al. (2006) \\
\hline Asterochloris clade 9 & $\begin{array}{l}\text { Cladonia cariosa, C. coniocraea, C. delavayi, } \\
\text { C. fruticulosa, C. praetermissa, C. scabriuscula, } \\
\text { C. verticillata }\end{array}$ & Řidká et al. (2014) \\
\hline Asterochloris clade 12 & Cladonia pyxidata & Řidká et al. (2014) \\
\hline Asterochloris clade 16 & Cladonia fruticulosa & Řidká et al. (2014) \\
\hline A. echinata & Lepraria caesioalba, L. rigidula & Škaloud et al. (2015) \\
\hline A. erici & $\begin{array}{l}\text { Cladonia calycanta, C. chlorophaea, C. crispata, } \\
\text { C. floerkeana, C. gracilis ssp. turbinata, C. ramulosa, } \\
\text { C. squamosissima }\end{array}$ & Nakano \& Iguchi (1994). id: LM, culture. \\
\hline
\end{tabular}


Table 1. (Continued)

\begin{tabular}{|c|c|c|}
\hline Alga & Fungal symbionts & References \& comments \\
\hline Asterochloris excentrica & Lepraria caesioalba, L. neglecta, L. rigidula & Škaloud \& Peksa (2010) \\
\hline A. friedlii & Lepraria caesioalba, L. lobificans & Škaloud et al. (2015) \\
\hline A. friedlii & Lepraria achariana, L. finkii & Kosecka et al. (2021) \\
\hline A. friedlii & Cladonia fimbriata & Pino-Bodas \& Stenroos (2020) \\
\hline A. gaertneri & Lepraria incana, L. rigidula & Škaloud et al. (2015) \\
\hline A. glomerata & Cladonia humilis & Nakano \& Iguchi (1994). id: LM, culture. \\
\hline A. glomerata & Diploschistes muscorum & Škaloud \& Peksa (2010) \\
\hline A. glomerata & Stereocaulon pileatum, S. saxatile, Stereocaulon sp. & Peksa \& Škaloud (2011) \\
\hline A. glomerata & $\begin{array}{l}\text { Cladonia coniocraea, C. squamosa, Stereocaulon } \\
\text { evolutoides, S. pileatum }\end{array}$ & Řidká et al. (2014) \\
\hline A. glomerata & Cladonia deformis, C. pleurota & Steinová et al. (2019) \\
\hline A. glomerata & Cladonia grayi & Armaleo et al. (2019) \\
\hline A. glomerata & $\begin{array}{l}\text { C. caroliniana, C. cornuta, C. deformis, C. hondoensis, } \\
\text { C. krogiana, C. mitis, C. monomorpha, C. oricola, } \\
\text { C. phyllophora, C. piedmontensis, C. pleurota, } \\
\text { C. submitis, C. subulata, C. uncialis }\end{array}$ & Pino-Bodas \& Stenroos (2020) \\
\hline A. glomerata/irregularis clade & $\begin{array}{l}\text { Cladonia cariosa, C. cervicornis ssp. verticillata, } \\
\text { C. phyllophora }\end{array}$ & Rola et al. (2021) \\
\hline A. irregularis & Squamarina lentigera & Beck et al. (2002) \\
\hline A. irregularis & $\begin{array}{l}\text { Cladonia furcata, Lecidea fuscoatra, L. plana, Lepraria } \\
\text { caesioalba, Porpidia crustulata, P. flavocaerulescens, } \\
\text { P. macrocarpa, Porpidia spp., Stereocaulon vesuvianum }\end{array}$ & Beck (2002) \\
\hline A.irregularis & $\begin{array}{l}\text { Cladonia arbuscula, C. mitis, Stereocaulon botryosum, } \\
\text { S. pileatum, S. subcoralloides }\end{array}$ & Škaloud \& Peksa (2010); Škaloud et al. (2015). \\
\hline A. irregularis & $\begin{array}{l}\text { Stereocaulon alpinum, S. apocalypticum, } \\
\text { S. intermedium, S. paschale, S. symphycheilum, } \\
\text { S. tomentosum, S. vesuvianum }\end{array}$ & Vančurová (2012) \\
\hline A. irregularis & $\begin{array}{l}\text { Stereocaulon botryosum, S. pileatum, S. subcoralloides, } \\
\text { S. vesuvianum, Stereocaulon sp. }\end{array}$ & Peksa \& Škaloud (2011) \\
\hline A. irregularis & Cladonia deformis, C. pleurota & Steinová et al. (2019) \\
\hline A. irregularis & $\begin{array}{l}\text { Cladonia albonigra, C. alinii, C. amaurocraea, C. botrytes, } \\
\text { C. crispata, C. ecmocyna, C. gracilis, C. granulans, } \\
\text { C. kanewskii, C. labradorica, C. macrophylla, C. uliginosa, } \\
\text { C. uncialis }\end{array}$ & Pino-Bodas \& Stenroos (2020) \\
\hline A. italiana & Cladonia capitellata, C. scabriuscula & Škaloud et al. (2015) \\
\hline A. italiana & Cladonia coccifera, C. diversa & Steinová et al. (2019) \\
\hline A. italiana & Stereocaulon condensatum & Vančurová (2012) \\
\hline A. italiana & $\begin{array}{l}\text { Cladonia bellidiflora, C. borbonica, C. brevis, C. callosa, } \\
\text { C. capitellata, C. ciliata, C. foliacea, C. groenlandica, } \\
\text { C. islandica, C. lepidophora, C. mawsonii, } \\
\text { C. merochlorophaea, C. neozelandica, C. pleurota, } \\
\text { C. portentosa, C. prolifica, C. pulvinata, C. rappi, C. rigida, } \\
\text { C. subcervicornis, C. subsubulata, C. ustulata, } \\
\text { C. weymouthii }\end{array}$ & Pino-Bodas \& Stenroos (2020) \\
\hline A. italiana clade & Diploschistes muscorum & Rola et al. (2021) \\
\hline A. leprarii & Lepraria caesioalba, L. neglecta & Škaloud et al. (2015) \\
\hline A. lobophora & $\begin{array}{l}\text { Cladonia cf. bacillaris, Diploschistes muscorum, Lepraria } \\
\text { alpina, L. borealis, L. caesioalba }\end{array}$ & Škaloud et al. (2015) \\
\hline A. lobophora & Cladonia coccifera & Steinová et al. (2019) \\
\hline A. lobophora & Cladonia rei & Pino-Bodas \& Stenroos (2020) \\
\hline
\end{tabular}


Table 1. (Continued)

\begin{tabular}{|c|c|c|}
\hline Alga & Fungal symbionts & References \& comments \\
\hline $\begin{array}{l}\text { Asterochloris lobophora/ } \\
\text { phycobiontica clade }\end{array}$ & Cladonia cariosa, C. rei, Diploschistes muscorum & Rola et al. (2021) \\
\hline A. magna & Porpidia contraponenda & Beck (2002) \\
\hline A. magna & Cladonia chlorophaea, C. decorticata & Pino-Bodas \& Stenroos (2020) \\
\hline A. mediterranea & $\begin{array}{l}\text { Cladonia cervicornis, C. concoluta, C. foliacea, } \\
\text { C. rangiformis }\end{array}$ & Moya et al. (2015) \\
\hline A. mediterranea & Cladonia calycantha, Stereocaulon pachycephalum & Kosecka et al. (2021) \\
\hline A. mediterranea & $\begin{array}{l}\text { Cladonia corsicana, C. crispata, C. cryptochlorophaea, } \\
\text { C. diversa, C. glauca, C. rei }\end{array}$ & Pino-Bodas \& Stenroos (2020) \\
\hline A. phycobiontica & Anzina [Varicellaria] carneonivea & Tschermak-Woess (1980a); Škaloud et al. (2015). \\
\hline A. phycobiontica & Stereocaulon alpinum & Vančurová (2012) \\
\hline A. phycobiontica & Lepraria neglecta & Škaloud \& Peksa (2010) \\
\hline A. phycobiontica & Lepraria alpina, L. caesioalba, L. neglecta, Lepraria sp. & Peksa \& Škaloud (2011) \\
\hline A. pseudoirregularis & Cladonia gracilis, Cladonia sp. & Kim et al. (2020) \\
\hline A. pseudoirregularis & $\begin{array}{l}\text { Cladonia amaurocraea, C. gracilis, C. granulans, } \\
\text { C. vulcanii, Pycnothelia papillaria }\end{array}$ & Pino-Bodas \& Stenroos (2020) \\
\hline A. sejongensis & Cladonia pyxidata, Sphaerophorus globosus & Kim et al. (2017) \\
\hline A. stereocaulonicola & Stereocaulon alpinum & Kim et al. (2020) \\
\hline A. woessiae & $\begin{array}{l}\text { Cladonia foliacea, Lepraria borealis, L. caesioalba, } \\
\text { L. crassissima, L. nigrocinta, L. nylanderiana, Lepraria } \\
\text { sp., Stereocaulon saxatile }\end{array}$ & Škaloud et al. (2015) \\
\hline A. woessiae & Cladonia coccifera & Steinová et al. (2019) \\
\hline A. woessiae & Cladonia conista, C. foliacea & Pino-Bodas \& Stenroos (2020) \\
\hline A. woessiae clade & Diploschistes muscorum & Rola et al. (2021) \\
\hline Asterochloris sp. & Bagliettoa cazzae & Thüs et al. (2011) \\
\hline Asterochloris sp. & Psora decipiens & $\begin{array}{l}\text { Ruprecht et al. (2014). Also Trebouxias and a } \\
\text { Chloroidium in this lichen sp., but see Williams et al. } \\
\text { (2017). }\end{array}$ \\
\hline Asterochloris sp. & Lepraria borealis, Ochrolechia frigida & Engelen et al. (2010, 2016). Maritime Antarctica. \\
\hline Asterochloris sp. & Lecidea lurida, Psora decipiens, Squamarina cartilaginea & Schaper \& Ott (2003). Gotland, Sweden. \\
\hline Asterochloris sp. & Ramalina farinacea & Moya et al. (2017). Minority photobiont. \\
\hline Asterochloris sp. & Porpidia from southern South America & $\begin{array}{l}\text { Ruprecht et al. (2020). All mycobiont species also } \\
\text { partnered with Trebouxia. }\end{array}$ \\
\hline Asterochloris sp. & $\begin{array}{l}\text { Cladonia acuata, C. aggregata, C. andesita, C. arbuscula } \\
\text { ssp. boliviana, C. calycantha, C. chlorophaea, C. confusa, } \\
\text { C. dactylota, C. didyma, C. furcata, C. granulosa, } \\
\text { C. isabellina, C. melanopoda, C. pocillum, C. ramulosa, C. } \\
\text { cf. subradiosa, C. vouauxii, Lepraria cryptovouauxii, } \\
\text { L. hodkinsoniana, Stereocaulon myriocarpum, } \\
\text { S. tomentosum }\end{array}$ & Kosecka et al. (2021) \\
\hline Asterochloris sp. & $\begin{array}{l}\text { Cladonia arbuscula, C. fimbriata, C. foliacea, C. rei, } \\
\text { Diploschistes muscorum, Lepraria alpina, L. borealis, } \\
\text { L. caesioalba, L. lobificans, L. neglecta, L. nigrocincta, } \\
\text { L. nylanderiana, L. rigidula, Pilophorus sp., Stereocaulon } \\
\text { botryosum, S. paschale, S. pileatum, S. saxatile, } \\
\text { S. subcoralloides, S. tomentosum, S. vesuvianum }\end{array}$ & $\begin{array}{l}\text { Nelsen \& Gargas (2008). Formal emendation of genus } \\
\text { by Škaloud \& Peksa (2010) to include Trebouxia } \\
\text { subgen. Eleutherococcus Tschermak-Woess. }\end{array}$ \\
\hline Asterochloris sp. & $\begin{array}{l}\text { Cladia aggregata, Cladonia cf. bacillaris, C. evansii, C. } \\
\text { fimbriata, C. perforata, C. rangiferina, Lepraria } \\
\text { atromentosa, L. caesiella, L. caesioalba, L. incana, } \\
\text { L. lobificans, L. nigrocincta, L. nivalis, L. nylanderiana, } \\
\text { Lepraria spp., Pilophorus acicularis, P. cf. cereolus, } \\
\text { Stereocaulon dactylophyllum, S. paschale, S. saxatile, } \\
\text { S. tomentosum, S. vesuvianum, Stereocaulon spp. }\end{array}$ & Nelsen \& Gargas (2008) \\
\hline
\end{tabular}


Table 1. (Continued)

\begin{tabular}{|c|c|c|}
\hline Alga & Fungal symbionts & References \& comments \\
\hline Asterochloris spp. & Species of Lepraria and Stereocaulon & Peksa \& Škaloud (2011) \\
\hline Asterochloris spp. & Cladonia furcata & Řidká et al. (2014) \\
\hline Myrmecia biatorellae & $\begin{array}{l}\text { Catapyrenium rufescens, Dermatocarpon hepaticum, } \\
\text { D. tuckermani, D. velebiticum, Lecidea berengeriana, } \\
\text { Lobaria linita, Polysporina simplex, Psora decipiens, } \\
\text { P. globifera, Psoroma hypnorum, Sarcogyne privigna, } \\
\text { Verrucaria submersella }\end{array}$ & Tschermak-Woess (1988a) \\
\hline M. biatorellae & Fuscidea cyathoides var. japonica, Leproloma sp. & Watanabe et al. (1997). Maritime lichens. id: LM. \\
\hline M. biatorellae & Placidium squamulosum & Voytsekhovich \& Beck (2016) \\
\hline M. biatorellae & $\begin{array}{l}\text { Heteroplacidium contumescens, } H . \text { imbricatum, } \\
\text { Placidium acarosporoides, P. arboreum, P. chilense, } \\
\text { P. lachneum, P. lacinulatum, P. squamulosum, } \\
\text { P. umbrinum (Verrucariaceae) }\end{array}$ & Thüs et al. (2011) \\
\hline M. biatorellae & Psora decipiens & Williams et al. (2017). Austrian samples. \\
\hline M. israelensis & $\begin{array}{l}\text { Psora decipiens, P. saviczii, Placidium pilosellum, } \\
\text { Placidium spp., Clavascidium spp. }\end{array}$ & Moya et al. (2018) \\
\hline Myrmecia sp. & Psora decipiens & $\begin{array}{l}\text { Williams et al. (2017). Transplant study; algal layer } \\
\text { degenerates, no photobiont switching. }\end{array}$ \\
\hline Trebouxia aggregata & Xanthoria parietina & Beck \& Mayr (2012) \\
\hline T. angustilobata & $\begin{array}{l}\text { Acarospora sinopica, Porpidia tuberculosa, Tremolecia } \\
\text { atrata }\end{array}$ & Beck (2002) \\
\hline T. angustilobata & Protoparmelia badia & Singh et al. (2017) \\
\hline T. angustilobata & Pseudephebe sp. & Garrido-Benavent et al. (2020) \\
\hline T. arboricola & $\begin{array}{l}\text { Lecania cyrtella, Lecanora sp., Lecidella elaeochroma, } \\
\text { Xanthoria parietina }\end{array}$ & Beck et al. (1998) \\
\hline T. arboricola & Anaptychia ciliaris & Helms et al. (2001); Dahlkild et al. (2001). \\
\hline T arboricola & Pleurosticta acetabulum & Beck \& Koop (2001) \\
\hline T. arboricola & Chaenotheca phaeocephala & Tibell \& Beck (2002) \\
\hline T. arboricola & Ramalina farinacea, $R$. pollinaria, $R$. siliquosa & Tschaikner et al. (2007). id: LM, cultures. \\
\hline T. arboricola & Caloplaca fernandeziana, C. orthoclada & Vargas Castillo \& Beck (2012) \\
\hline T. arboricola & $\begin{array}{l}\text { Xanthoria aureola, X. calcicola, X. capensis, } \\
\text { X. ectaneoides, X. flammea, X. hirsuta, X. karrooensis, } \\
\text { X. ligulata, X. parietina, X. polycarpa, X. turbinata }\end{array}$ & Nyati et al. $(2013,2014)$ \\
\hline T. arboricola & Ochrolechia sp., Xanthoria calcicola, X. parietina & Voytsekhovich \& Beck (2016) \\
\hline T. arboricola clade & Acarospora conafii, Ramalina thrausta & Jung et al. (2019) \\
\hline T. arboricola/T. gigantea clade & Xanthoparmelia spp. & Leavitt et al. (2013) \\
\hline T. arboricola/T. gigantea clade & Cladonia cariosa, C. rei, Diploschistes muscorum & Osyczka et al. (2021) \\
\hline $\begin{array}{l}\text { Clade A (= arboricola/gigantea } \\
\text { group) }\end{array}$ & $\begin{array}{l}\text { Species of Melanelixia, Melanohalea, Montanelia, } \\
\text { Oropogon, Parmotrema, Protoparmeliopsis, Rhizoplaca } \\
\text { and Xanthoparmelia }\end{array}$ & Leavitt et al. (2015) \\
\hline T. 'arnoldoi' & Buellia zoharyi & Molins et al. (2020) \\
\hline T. asymmetrica & Buellia zoharyi & Helms et al. (2001); Molins et al. (2020). \\
\hline T. asymmetrica & Fulgensia fulgida, Toninia sedifolia & Beck et al. (2002) \\
\hline T. asymmetrica & Protoparmeliopsis muralis & Guzow-Krzemińska (2006) \\
\hline T. asymmetrica & Caloplaca teicholyta, Circinaria contorta & Voytsekhovich \& Beck (2016) \\
\hline T. asymmetrica & Circinaria spp. & Molins et al. (2018) \\
\hline T. asymmetrica clade & Placidium sp. & Jung et al. (2019) \\
\hline T. australis & $\begin{array}{l}\text { Lecanora farinacea, L. polytropa, Rhizocarpon } \\
\text { geographicum }\end{array}$ & Beck (2002) \\
\hline
\end{tabular}


Table 1. (Continued)

\begin{tabular}{|c|c|c|}
\hline Alga & Fungal symbionts & References \& comments \\
\hline Trebouxia brindabellae & Protoparmelia badia & Singh et al. (2017) \\
\hline T. corticola & Parmotrema tinctorum & Ohmura et al. $(2006,2019)$ \\
\hline T. corticola & Umbilicaria muehlenbergii & Cao et al. (2015) \\
\hline T. crenulata & Ramalina capitata & Tschaikner et al. (2007) \\
\hline T. crenulata & Xanthoria parietina & Beck \& Mayr (2012) \\
\hline T. crenulata & $\begin{array}{l}\text { Caloplaca aurantia, C. xerica, Candelariella medians, } \\
\text { Lecanora swartzii, Leproplaca xantholyta, Tephromela } \\
\text { atra, Xanthoria calcicola }\end{array}$ & Voytsekhovich \& Beck (2016) \\
\hline T. crespoana & Parmotrema pseudotinctorum & Škaloud et al. (2018) \\
\hline T. cretacea & Aspicilia desertorum, Rusavskia papillifera & Voytsekhovich \& Beck (2016) \\
\hline T. cretacea & Buellia zoharyi & Molins et al. (2020) \\
\hline T. decolorans & Lecanora rupicola & Blaha et al. (2006) \\
\hline T. decolorans & Xanthoria parietina & Beck \& Mayr (2012) \\
\hline T. decolorans & $\begin{array}{l}\text { Xanthomendoza borealis, Xm. fulva, Xm. hasseana, } \\
\text { Xanthoria candelaria, X. elegans, X. parietina, } \\
\text { X. polycarpa }\end{array}$ & Nyati et al. $(2013,2014)$ \\
\hline T. decolorans & Ramalina menziesii & Werth \& Sork (2014) \\
\hline T. decolorans & Caloplaca orthoclada & Vargas Castillo \& Beck (2012) \\
\hline T. decolorans & Ramalina fraxinea & Catalá et al. (2016) \\
\hline T. decolorans & Anaptychia ciliaris, Xanthoria parietina & Dal Grande et al. (2014a) \\
\hline T. decolorans & Anaptychia setifera, Candelariella medians & Voytsekhovich \& Beck (2016) \\
\hline $\begin{array}{l}\text { Trebouxia clade G (galapagensis/ } \\
\text { usneae group) }\end{array}$ & Species of Parmotrema and Xanthoparmelia & Leavitt et al. (2015) \\
\hline T. gelatinosa & $\begin{array}{l}\text { Caloplaca spp., Hymenelia sp., Lecanora subimmergens, } \\
\text { Lecidella enteroleucella, Ochrolechia parellula, Rinodina } \\
\text { sp., Verrucaria sp. }\end{array}$ & Watanabe et al. (1997). Maritime lichens. id: LM. \\
\hline T. gelatinosa & Physcia semipinnata & Helms et al. (2001) \\
\hline T. gelatinosa & $\begin{array}{l}\text { Flavoparmelia caperata, Punctelia subrudecta, } \\
\text { Teloschistes sp., Xanthoria sp. }\end{array}$ & Doering \& Piercey-Normore (2009) \\
\hline T. gelatinosa & $\begin{array}{l}\text { Josefpoeltia parva, Teloschistes chrysophthalmus, } \\
\text { T. hosseusianus, Xanthomendoza novozelandica, Xm. } \\
\text { weberi }\end{array}$ & Nyati et al. $(2013,2014)$ \\
\hline T. gelatinosa & Rhizocarpon geographicum & Voytsekhovich \& Beck (2016) \\
\hline T. gigantea & Parmelia subramigera & Watanabe et al. (1997). Maritime. id: LM. \\
\hline T. gigantea & Rinodinella controversa & Helms et al. (2001) \\
\hline T. gigantea & Protoparmeliopsis muralis & Guzow-Krzemińska (2006) \\
\hline T. gigantea & Caloplaca orthoclada & Vargas Castillo \& Beck (2012) \\
\hline T. gigantea & Caloplaca erythrocarpia, Candelariella medians & Voytsekhovich \& Beck (2016) \\
\hline T. glomerata & Species of Polyblastia, Rinodina and Verrucaria & Watanabe et al. (1997). Maritime lichens. id: LM. \\
\hline T. higginsiae & $\begin{array}{l}\text { Aspicilia sp., Buellia stellulata, Caloplaca kobeana, } \\
\text { Hymenelia sp., Lecidella enteroleucella, Parmelia } \\
\text { congensis, Rhizocarpon sp., Rinodina sp., Rinodinella sp. }\end{array}$ & Watanabe et al. (1997). Maritime lichens. id: LM. \\
\hline 'T. hypogymniae' & Hypogymnia physodes & Hauck et al. (2007) \\
\hline 'T. hypogymniae' & Evernia divaricata, E. mesomorpha & Piercey-Normore (2009) \\
\hline T. impressa & Parmelia mexicana & Watanabe et al. (1997). Maritime lichens. id: LM. \\
\hline T. impressa & Phaeophyscia orbicularis, Physcia adscendens, P. tenella & Beck et al. (1998); Helms et al. (2001). \\
\hline T. impressa & $\begin{array}{l}\text { Dimelaena oreina, Physcia aipola, Physconia perisidiosa, } \\
\text { Rinodina capensis, R. milvina }\end{array}$ & Helms et al. (2001) \\
\hline
\end{tabular}


Table 1. (Continued)

\begin{tabular}{|c|c|c|}
\hline Alga & Fungal symbionts & References \& comments \\
\hline Trebouxia impressa & $\begin{array}{l}\text { Phaeophyscia orbicularis, Physcia caesia, P. tenella, } \\
\text { Physconia distorta }\end{array}$ & Dahlkild et al. (2001) \\
\hline T. impressa & Umbilicaria kappenii & Romeike et al. (2002) \\
\hline T. impressa & $\begin{array}{l}\text { Melanelia glabra, Parmelina carporrhizans, P. tiliacea, } \\
\text { Phaeophyscia orbicularis, Physcia caesia, P. stellaris, } \\
\text { P. tenella }\end{array}$ & Doering \& Piercey-Normore (2009) \\
\hline T. impressa & Xanthomendoza fallax, X. ulophyllodes & Nyati et al. (2014) \\
\hline T. impressa & Lecanora rupicola & Blaha et al. (2006) \\
\hline T. impressa & $\begin{array}{l}\text { Lecanora fuscobrunnea, Lecidea andersonii, } \\
\text { L. atrobrunnea, L. cancriformis, L. tesselata, Lecidella } \\
\text { carpathica }\end{array}$ & Ruprecht et al. (2012) \\
\hline T. impressa & Thamnolia vermicularis & Onuţ-Brännström et al. (2017) \\
\hline T. impressa/T. gelatinosa & Cladonia cariosa, C. rei, Diploschistes muscorum & Osyczka et al. (2021) \\
\hline Clade I (impressa/gelatinosa group) & $\begin{array}{l}\text { Species of Melanelixia, Melanohalea, Montanelia, } \\
\text { Oropogon, Parmelia, Protoparmeliopsis, Rhizoplaca and } \\
\text { Xanthoparmelia }\end{array}$ & Leavitt et al. (2015) \\
\hline T. impressa/T. potteri & Ramalina americana, $R$. sinensis & Francisco de Oliveira et al. (2012) \\
\hline T. impressa/T. potteri & Pleurosticta koflerae & Voytsekhovich \& Beck (2016) \\
\hline $\begin{array}{l}\text { Trebouxia clade including } \\
\text { T. impressa, T. flava and T. potteri }\end{array}$ & Physconia distorta, $P$. grisea & Wornik \& Grube (2010) \\
\hline T. incrustata & Xanthoria candelaria & Aoki et al. (1998). Antarctica. id: LM, culture. \\
\hline T. incrustata & Rinodina atrocinerea & Helms et al. (2001) \\
\hline T. incrustata & $\begin{array}{l}\text { Acarospora bullata, Lecanora muralis, L. stenotropa, } \\
\text { Neofuscelia stygiodes, Protoparmelia badia, Rhizocarpon } \\
\text { cf. cyanescens, } R \text {. cf. viridiatrum }\end{array}$ & Beck (2002) \\
\hline T. incrustata & Lecanora rupicola & Blaha et al. (2006) \\
\hline T. incrustata & Protoparmelia incrustans & Muggia et al. (2013) \\
\hline T. incrustata & Protoparmeliopsis muralis & Guzow-Krzemińska (2006) \\
\hline T. incrustata & $\begin{array}{l}\text { Caloplaca crenulatella, C. squamulosa, Circinaria } \\
\text { contorta, Lecanora muralis, Staurothele sp., } \\
\text { Xanthoparmelia pulla, X. stenophylla }\end{array}$ & Voytsekhovich \& Beck (2016) \\
\hline T. irregularis & Diploschistes muscorum & $\begin{array}{l}\text { Friedl (1989). Photobiont taken from parasitized } \\
\text { Cladonia; later substituted by T. showmanii. id: LM. }\end{array}$ \\
\hline T. jamesii & Candelaria concolor, Candelariella sp. & Beck et al. (1998) \\
\hline T. jamesii & Tremolecia atrata & Beck \& Koop (2001) \\
\hline T. jamesii & Chaenotheca subroscida & Tibell \& Beck (2002) \\
\hline T. jamesii & $\begin{array}{l}\text { Umbilicaria antarctica, U. decussata, U. kappenii, } \\
\text { U. umbilicarioides }\end{array}$ & Romeike et al. (2002) \\
\hline T. jamesii & Evernia mesomorpha, Melanelia exasperatula & Piercey-Normore $(2006,2009)$. Multiple clades within. \\
\hline T. jamesii & $\begin{array}{l}\text { Evernia divaricata, E. prunastri, Ramalina fraxinea, } \\
\text { R. siliquosa }\end{array}$ & Tschaikner et al. (2007) \\
\hline T. jamesii & Ramalina farinacea & Casano et al. (2011); Moya et al. (2017). \\
\hline T. jamesii & Ramalina fraxinea & Catalá et al. (2016) \\
\hline T. jamesii & $\begin{array}{l}\text { Carbonea vorticosa, Lecanora fuscobrunnea, } \\
\text { L. physciella, Lecidea auriculata, L. cancriformis, } \\
\text { L. lapicida, L. obluridata, Lecidella greenii, L. siplei }\end{array}$ & Ruprecht et al. (2012) \\
\hline T. jamesii & Lecidea cancriformis & $\begin{array}{l}\text { Pérez-Ortega et al. (2012). Hap4, well-supported } \\
\text { clade. }\end{array}$ \\
\hline T. jamesii & Lepraria borealis & Engelen et al. (2010). Maritime Antarctica. \\
\hline
\end{tabular}


Table 1. (Continued)

\begin{tabular}{|c|c|c|}
\hline Alga & Fungal symbionts & References \& comments \\
\hline Trebouxia jamesii & Ramalina menziesii & $\begin{array}{l}\text { Werth \& Sork (2014). Only } 6 \% \text { of sampled thalli; } \\
\text { majority had T. decolorans. }\end{array}$ \\
\hline T. jamesii & $\begin{array}{l}\text { Candelariella vitellina, Lecanora frustulosa, Lecidea sp., } \\
\text { Protoparmelia psarophana, Ramalina calicaris, } \\
\text { R. capitata, R. pollinaria, R. pontica, Ramalina sp., } \\
\text { Rhizocarpon geographicum, Rhizoplaca sp., Umbilicaria } \\
\text { grisea }\end{array}$ & Voytsekhovich \& Beck (2016) \\
\hline T. jamesii & Protoparmelia badia, P. montagnei & Singh et al. (2017) \\
\hline $\begin{array}{l}\text { T. jamesii } \\
\text { clade 'T. lethariae' }\end{array}$ & Letharia barbata, L. gracilis, L. lucida, L. lupina, L. rugosa & Kroken \& Taylor (2000) \\
\hline $\begin{array}{l}\text { T. jamesii } \\
\text { clade 'T. vulpinae' }\end{array}$ & Letharia vulpina & Kroken \& Taylor (2000) \\
\hline $\begin{array}{l}\text { T. jamesii } \\
\text { clade 'T. vulpinae' }\end{array}$ & Cetraria aculeata & $\begin{array}{l}\text { Fernández-Mendoza et al. (2011); Onuţ-Brännström } \\
\text { et al. (2018). }\end{array}$ \\
\hline $\begin{array}{l}\text { T. jamesii and Trebouxia clades A, I, } \\
\text { S, G }\end{array}$ & Thamnolia vermicularis & Nelsen \& Gargas (2009) \\
\hline T. jamesii 'group A' & $\begin{array}{l}\text { Boreoplaca ultrafrigida, Umbilicaria esculenta, } \\
\text { U. muehlenbergii }\end{array}$ & Cao et al. (2015) \\
\hline T. jamesii 'group B' & Boreoplaca ultrafrigida, U. muehlenbergii & Cao et al. (2015) \\
\hline T. jamesii ssp. angustilobata & Acarospora sinopica, Lecidea lapicida & Beck (1999) \\
\hline T. jamesii ssp. jamesii & $\begin{array}{l}\text { Acarospora rugulosa, Bellemerea diamartha, Lecanora } \\
\text { polytropa, L. subaurea, Lecidea silacea, Rhizocarpon } \\
\text { geographicum, Umbilicaria cylindrica }\end{array}$ & Beck (1999) \\
\hline T. potteri & Pertusaria spp. & Takeshita et al. (1989). id: LM, culture. \\
\hline T. potteri/flava & Lecanora rupicola & Blaha et al. (2006) \\
\hline T. showmanii & Caloplaca spp. & $\begin{array}{l}\text { Watanabe et al. (1997). Maritime lichens. id: LM, } \\
\text { culture. }\end{array}$ \\
\hline T. showmanii & Diploschistes muscorum & Friedl (1989). id: LM. \\
\hline T. simplex & $\begin{array}{l}\text { Acarospora rugulosa, A. sinopica, A. smaragdula, } \\
\text { Bellemerea alpina, B. cinereorufescens, B. subsorediza, } \\
\text { Carbonea vorticosa, Lecidea confluens, L. epanora, } \\
\text { L. handelii, L. lapicida, L. paupercula, L. polytropa, } \\
\text { L. silacea, L. subaurea, L. tesselata, Miriquidica atrofulva, } \\
\text { M. garovaglii, Pleopsidium chlorophanum, Porpidia } \\
\text { tuberculosa, Rhizocarpon geographicum, R. lecanorinum, } \\
\text { R. norvegicum, R. polycarpum, R. ridescens, } \\
\text { R. simillimum, Sporastatia testudinea, Tremolecia atrata, } \\
\text { Umbilicaria crustulosa, U. cylindrica, U. torrefacta }\end{array}$ & Beck (2002) \\
\hline T. simplex & Lecanora rupicola & Blaha et al. (2006) \\
\hline T. simplex & Lecanora conizaeoides & Hauck et al. (2007) \\
\hline T. simplex & $\begin{array}{l}\text { Evernia mesomorpha, Everniastrum catawbiense, } \\
\text { Imshaugia aleurites, Pseudevernia consocians }\end{array}$ & Piercey-Normore (2009) \\
\hline T. simplex & $\begin{array}{l}\text { Evernia mesomorpha, Imshaugia placorodia, Lecanora } \\
\text { conizaeoides, Pseudevernia cladoniae, P. consocians }\end{array}$ & Doering \& Piercey-Normore (2009) \\
\hline T. simplex & $\begin{array}{l}\text { Bryoria americana, B. bicolor, B. capillaris, B. fremontii, } \\
\text { B. furcellata, B. glabra, B. implexa, B. lanestris, } \\
\text { B. nadvornikiana, B. nitidula, B. simplicior, B. smithii, } \\
\text { B. subcana, B. tenuis, Bryoria sp. }\end{array}$ & Lindgren et al. (2014) \\
\hline T. simplex & Protoparmelia hypotremella, P. ochrococca, P. oleagina & Singh et al. (2017) \\
\hline T. simplex & Thamnolia vermicularis & Onuţ-Brännström et al. (2017) \\
\hline T. simplex/jamesii & Lasallia pustulata, L. hispanica, Umbilicaria spodochroa & Hestmark et al. (2016); Dal Grande et al. (2018). \\
\hline $\begin{array}{l}\text { Clade S (simplex/letharii/jamesii } \\
\text { group) }\end{array}$ & $\begin{array}{l}\text { Species of Cetraria, Letharia, Melanohalea, Motanelia, } \\
\text { Rhizoplaca and Xanthoparmelia }\end{array}$ & Leavitt et al. (2015) \\
\hline
\end{tabular}


Table 1. (Continued)

\begin{tabular}{|c|c|c|}
\hline Alga & Fungal symbionts & References \& comments \\
\hline $\begin{array}{l}\text { Clade S (Trebouxia simplex/letharii/ } \\
\text { jamesii group) }\end{array}$ & Pseudephebe minuscula, P. pubescens & Garrido-Benavent et al. (2020) \\
\hline $\begin{array}{l}\text { T. simplex/suecica } \\
\text { (S clade) }\end{array}$ & $\begin{array}{l}\text { Cetraria aculeata, C. ericetorum, C. islandica, } \\
\text { C. muricata, C. sepincola, Flavocetraria cucullata, } \\
\text { F. nivalis, Melanelia agnata, M. hepatizon, M. stygia, } \\
\text { Tuckermannopsis chlorophylla, Vulpicida pinastri }\end{array}$ & Xu et al. (2020) \\
\hline T. simplex s. lat. & Tephromela atra s. str. & $\begin{array}{l}\text { Muggia et al. (2008). Tephromela photobionts also } \\
\text { found in two other Trebouxia clades. }\end{array}$ \\
\hline T. simplex subclades 1 and 2 & Cetraria aculeata, C. islandica, Thamnolia subuliformis & Onuţ-Brännström et al. (2018) \\
\hline Trebouxia solaris & $\begin{array}{l}\text { Aspicilia cinerea, Caloplaca aractina, Candelariella } \\
\text { vittelina, Circinaria contorta, Ramalina capitata, } \\
\text { Rhizocarpon geographicum }\end{array}$ & Voytsekhovich \& Beck (2016) \\
\hline T. aff. solaris & Chrysothrix candelaris & Ertz et al. (2018) \\
\hline T. aff. solaris & Lecanographa amylacea ('Buellia violaceofusca’) & $\begin{array}{l}\text { Ertz et al. (2018). Same mycobiont produces } \\
\text { morphologically distinct, sexual thallus with } \\
\text { Trentepohlia sp.! }\end{array}$ \\
\hline T. suecica & $\begin{array}{l}\text { Acarospora sinopica, Candelariella vitellina, Immersaria } \\
\text { athroocarpa, Lecanora polytropa, Miriquidica atrofulva, } \\
\text { Protoparmelia atriseda, P. badia, Rhizocarpon } \\
\text { geographicum, Tremolecia atrata, Umbilicaria torrefacta }\end{array}$ & Beck (2002) \\
\hline T. suecica & Protoparmelia badia, P. memnonia & Singh et al. (2017) \\
\hline T. suecica & Pseudephebe sp. & Garrido-Benavent et al. (2020) \\
\hline T. vagua & $\begin{array}{l}\text { Candelariella vitellina, Circinaria contorta, Diploschistes } \\
\text { diacapsis, Porpidia crustulata }\end{array}$ & Voytsekhovich \& Beck (2016) \\
\hline T. vagua & Thamnolia vermicularis & Onuţ-Brännström et al. (2017) \\
\hline Near T. vagua & $\begin{array}{l}\text { Caloplaca tubelliana, Dirina massiliensis } \\
\text { [Arthoniomycetes!], Lecanora albescens }\end{array}$ & Voytsekhovich \& Beck (2016) \\
\hline $\begin{array}{l}\text { Trebouxia clade IV (including } T \text {. } \\
\text { corticola, T. galapagensis, } \\
T \text {. higginsiae and T. usneae) }\end{array}$ & $\begin{array}{l}\text { Tropical Ramalina anceps, } R . \text { complanata, } R \text {. dendroides, } \\
R . \text { gracilis, } R . \text { peruviana, } R \text {. sorediosa, } R \text {. sprengelii }\end{array}$ & Cordeiro et al. (2005) \\
\hline Trebouxia A 02 & $\begin{array}{l}\text { Austrolechia sp., Buellia frigida, Carbonea vorticosa, } \\
\text { Huea sp., Lecidea cancriformis, L. polypycnidophora, } \\
\text { Lecidella greenii, Rhizoplaca macleanii }\end{array}$ & Wagner et al. (2020). Antarctic Dry Valleys. \\
\hline Trebouxia sp. clade 1 & Fulgensia bracteata, $F$. fulgens, Toninia sedifolia & Schaper \& Ott (2003). Götland, Sweden. \\
\hline Trebouxia sp. 'D11' & Buellia frigida, endolithic Lecidea sp., Umbilicaria aprina & de los Ríos et al. (2005). Continental Antarctic. \\
\hline Trebouxia TR9 & Ramalina farinacea & Casano et al. (2011); Moya et al. (2017). \\
\hline Trebouxia sp. 'URa1' & Carbonea vorticosa, Lecidea cancriformis & Ruprecht et al. (2012) \\
\hline Trebouxia sp. 'URa2' & $\begin{array}{l}\text { Carbonea vorticosa, Lecidea andersonii, L. atrobrunnea, } \\
\text { L. cancriformis, L. fuscoatra, L. lapicida, Lecidea sp., } \\
\text { Lecidella greenii, L. siplei, Rhizoplaca macleanii }\end{array}$ & Ruprecht et al. (2012) \\
\hline Trebouxia sp. 'URa3’ & $\begin{array}{l}\text { Carbonea vorticosa, Lecanora physciella, Lecidea } \\
\text { andersonii, L. cancriformis, L. lapicida, } \\
\text { L. polypycnidophora, Lecidella greenii, L. patavina, } \\
\text { L. siplei, Rhizoplaca macleanii }\end{array}$ & Ruprecht et al. (2012) \\
\hline Trebouxia sp. 'URa4’ & Lecidea andersonii, Lecidella stigmatea & Ruprecht et al. (2012) \\
\hline Trebouxia sp. & $\begin{array}{l}\text { Buellia papillata, Caloplaca johnstonii, C. lewis-smithii, } \\
\text { Candelariella flava, Lecidella pataviana, Lepraria } \\
\text { cacuminum, Pseudephebe minuscula, Psoroma sp., } \\
\text { Tephromela atra, T. disciformis, Usnea lambii, Xanthoria } \\
\text { elegans }\end{array}$ & Engelen et al. (2016). Maritime Antarctic. \\
\hline Trebouxia sp. & Bagliettoa marmorea & Thüs et al. (2011) \\
\hline Trebouxia sp. & Lasallia pustulata & Sadowksa-Deś et al. (2014) \\
\hline Trebouxia sp. & Cetraria aculeata & Lutsak et al. (2016) \\
\hline
\end{tabular}


Table 1. (Continued)

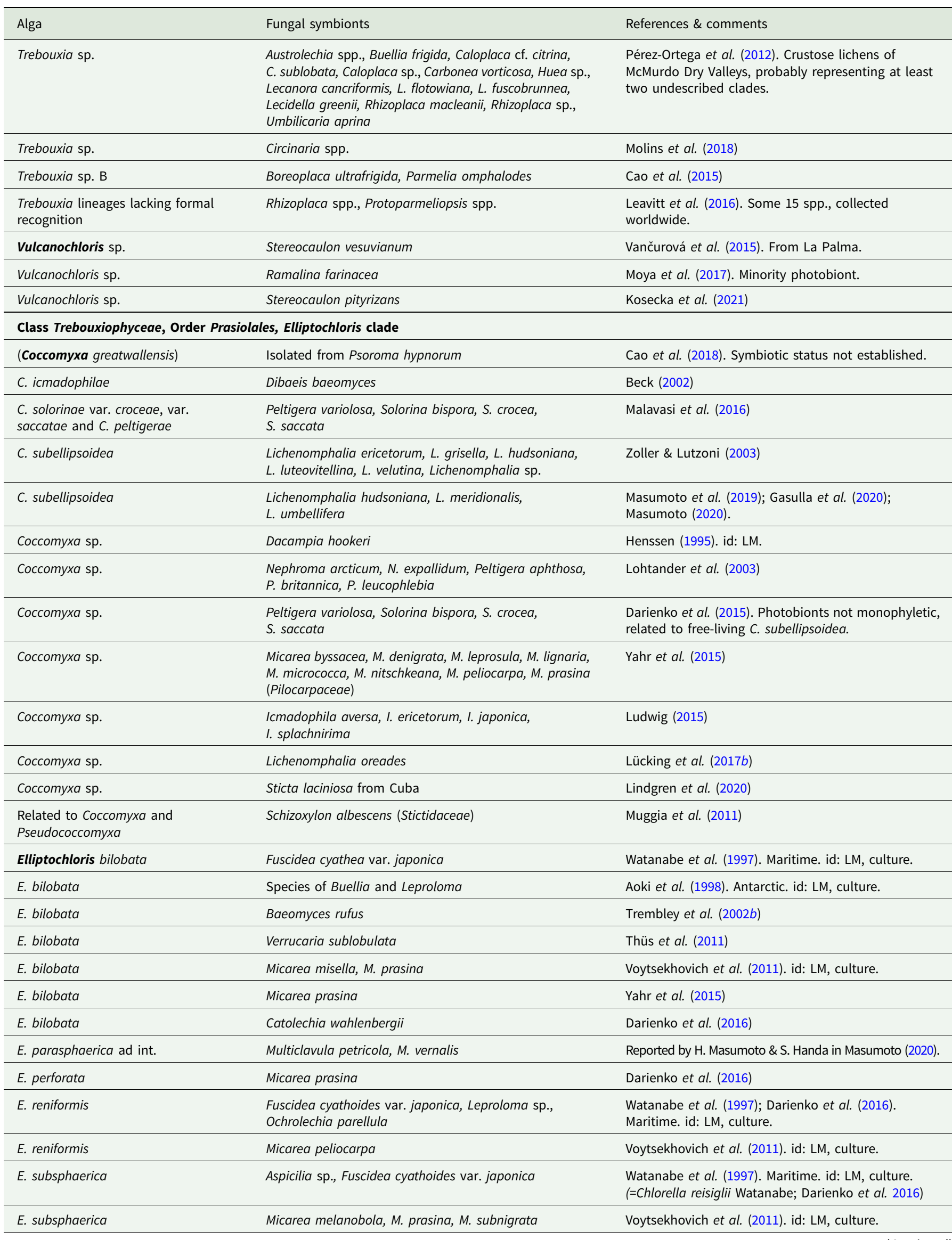


Table 1. (Continued)

\begin{tabular}{|c|c|c|}
\hline Alga & Fungal symbionts & References \& comments \\
\hline Elliptochloris subsphaerica & Multiclavula mucida & Masumoto (2020) \\
\hline Elliptochloris sp. & Stictis urceolatum & Thüs et al. (2011) \\
\hline Elliptochloris sp. & Catillaria chalybeia & Dal Grande et al. (2014b) \\
\hline Elliptochloris sp. & Ramalina farinacea & Moya et al. (2017). Minority photobiont. \\
\hline Elliptochloris sp. & Bryoclavula phycophila & Masumoto (2020) \\
\hline Elliptochloris sp. & Sticta filix, S. menziesii, S. stipitata, S. subcaperata & Lindgren et al. (2020) \\
\hline Pseudococcomyxa simplex & Leproloma sp. & Watanabe et al. (1997). Maritime. id: LM, culture. \\
\hline Pseudococcomyxa sp. & Micarea prasina & Voytsekhovich et al. (2011). id: LM, culture. \\
\hline \multicolumn{3}{|c|}{ Class Trebouxiophyceae, Order Watanabeales } \\
\hline Chloroidium angustoellipsoideum & Stereocaulon nanodes, S. spathuliferum & $\begin{array}{l}\text { Vančurová (2012); Vančurová et al. (2018). Darienko } \\
\text { et al. (2018): C. angustoellipsoideum now C. lichenum. }\end{array}$ \\
\hline C. ellipsoideum & Trapelia obtegens & Beck (2002) \\
\hline C. ellipsoideum & $\begin{array}{l}\text { Stereocaulon nanodes, S. pileatum, S. vesuvianum, } \\
\text { S. spathuliferum, Stereocaulon sp. }\end{array}$ & $\begin{array}{l}\text { Vančurová (2012); Vančurová et al. (2018). } \\
\text { Stereocaulon vesuvianum also hosts Asterochloris and } \\
\text { Vulcanochloris. }\end{array}$ \\
\hline Near C. ellipsoideum & Trapeliopsis flexuosa, T. granulosa & $\begin{array}{l}\text { Schmitt \& Lumbsch (2001). Amplified unintentionally } \\
\text { with non-specific primers. 'Chlorella' ellipsoidea } \\
\text { sequence X63520. Known photobionts of other } \\
\text { Trapeliaceae are in Prasiolales. }\end{array}$ \\
\hline C. saccharophilum & Trapelia coarctata & Tschermak-Woess (1988b) \\
\hline C. saccharophilum & Lecidea inops, Psilolechia leprosa, Stereocaulon nanodes & Beck (2002) \\
\hline C. saccharophilum & Psora decipiens & $\begin{array}{l}\text { Ruprecht et al. (2014). One record; all other thalli had } \\
\text { Asterochloris or Trebouxia. Contrast Williams et al. (2017). }\end{array}$ \\
\hline C. viscosum & Bacidina [Woessia] fusarioides & Tschermak-Woess (1988b); Darienko et al. (2018). \\
\hline Chloroidium sp. & Verrucaria praetermissa & $\begin{array}{l}\text { Thüs et al. (2011). Possibly an accessory alga rather } \\
\text { than main photobiont. }\end{array}$ \\
\hline Chloroidium sp. & Verrucaria nigrescens, Verrucaria sp. & Voytsekhovich \& Beck (2016). id: LM. \\
\hline Chloroidium sp. & Species of Gomphillus and Gyalidea & Sanders et al. (2016) \\
\hline Chloroidium sp. & Sticta latifrons, S. subcaperata & Lindgren et al. (2020) \\
\hline $\begin{array}{l}\text { Near Chloroidium and } \\
\text { Parachloroidium }\end{array}$ & Bapalmuia lineata & Sanders et al. (2016) \\
\hline $\begin{array}{l}\text { Heveochlorella sp. } \\
\text { (Jaagichlorella Darienko \& } \\
\text { Pröschold 2019) }\end{array}$ & Pseudocyphellaria sp., Sticta sp. & $\begin{array}{l}\text { Dal Grande et al. (2014b). Three specimens; authors } \\
\text { confident alga is photobiont. }\end{array}$ \\
\hline Heveochlorella sp. & $\begin{array}{l}\text { Aspidothelium cinerascens, A. fugiens, A. geminiparum } \\
\text { (Thelenellaceae); Aderkomyces heterellus, Echinoplaca } \\
\text { spp., Gyalectidium appendiculatum, G. floridense, } \\
\text { G. imperfectum, G. paolae, G. ulloae, Gyalideopsis } \\
\text { sessilis, Gyalideopsis sp. (Gomphillaceae); Byssoloma } \\
\text { discordans, Calopadia fusca, C. perpallida, C. puiggarii } \\
\text { (Pilocarpaceae) }\end{array}$ & Sanders et al. (2016). Mainly foliicolous. \\
\hline Heveochlorella sp. & $\begin{array}{l}\text { Sticta caperata, S. dichotoma, S. latifrons, S. squamata, } \\
\text { S. subcaperata, S. variabilis, Sticta spp. }\end{array}$ & Lindgren et al. (2020) \\
\hline $\begin{array}{l}\text { [unidentified, falling 'near' } \\
\text { Heterochlorella] }\end{array}$ & Psoroglaena epiphylla & Nyati et al. (2007); Thüs et al. (2011). \\
\hline \multicolumn{3}{|c|}{ Class Trebouxiophyceae, incertae sedis } \\
\hline Apatococcus lobatus & $\begin{array}{l}\text { Caloplaca sp., Fuscidea cyathoides var. japonica, } \\
\text { Lecanora subimmergens, Pyrenopsis sp., Verrucaria sp. }\end{array}$ & Watanabe et al. (1997). Maritime. id: LM. \\
\hline A. lobatus & Scoliciosporum umbrinum & Beck (2002) \\
\hline A. fuscideae & Fuscidea arboricola, F. cyathoides, F. kochiana, F. pusilla & Zahradníková et al. (2017) \\
\hline Apatococcus sp. & Fuscidea lightfootii & Zahradníková et al. (2017) \\
\hline
\end{tabular}


Table 1. (Continued)

\begin{tabular}{|c|c|c|}
\hline Alga & Fungal symbionts & References \& comments \\
\hline Coccobotrys verrucariae & Verrucaria nigrescens & Chodat (1913); Vischer (1960). \\
\hline Coccobotrys sp. (?) & Botryolepraria lesdainii & Canals et al. (1997). id: LM, culture. \\
\hline Dictyochloropsis splendida & Phlyctis argena & Tschermak-Woess (1995). id: LM. \\
\hline D. symbiontica & $\begin{array}{l}\text { Sphaerophorus diplotypus, S. fragilis, S. melanocarpus, } \\
\text { S. melophorus }\end{array}$ & Ihda et al. (1997). id: LM, culture. \\
\hline D. symbiontica & Species of Caloplaca and Leproloma & Watanabe et al. (1997). Maritime. id: LM. \\
\hline D. symbiontica & Lecania naegelii & Beck et al. (1998) \\
\hline Dictyochloropsis clade 2 & $\begin{array}{l}\text { Brigantiaea ferruginea, B. leucoxantha } \\
\text { (Brigantiaeaceae); Crocodia aurata, Lobaria oregana, } \\
\text { L. patinifera, L. pulmonaria, Lobariella crenulata, } \\
\text { L. pallidocrenulata, Lobariella sp., Pseudocyphellaria } \\
\text { fimbriata, P. homeophylla, P. lindsayi, P. lividofusca, } \\
\text { P. multifida, Sticta canariensis, S. latifrons, } \\
\text { S. pulmonariodes, S. subcaperata, Sticta spp. } \\
\text { (Lobariaceae); Megalospora sulphurata } \\
\text { (Megalosporaceae); Chaenothecopsis consociata } \\
\text { (Mycocaliciaceae); Phlyctis argena (Phlyctidaceae); } \\
\text { Biatora sp. (Ramalinaceae); Chaenotheca brunneola } \\
\text { (Coniocybomycetes) }\end{array}$ & $\begin{array}{l}\text { Dal Grande et al. (2014b). Dictyochloropsis. clade } 2= \\
\text { Symbiochloris; Škaloud et al. (2016). }\end{array}$ \\
\hline Leptosira terrestris & Vezdaea aestivalis & Tschermak-Woess \& Poelt (1976). id: LM, culture. \\
\hline L. thrombii & Thrombium epigaeum & Tschermak-Woess (1953). id: LM, culture. \\
\hline Neocystis sp. & Micarea misella & $\begin{array}{l}\text { Voytsekhovich et al. (2011). Reported as an 'additional } \\
\text { photobiont' to Elliptochloris. id: LM, culture. }\end{array}$ \\
\hline Symbiochloris sp. & $\begin{array}{l}\text { Brigantiaea ferruginea, B. leucoxantha (Brigantiaeaceae); } \\
\text { Crocodia aurata, Dendriscosticta platyphylla, D. wrightii; } \\
\text { Lobaria macaronesica, L. oregana, L. patinifera, } \\
\text { L. pulmonaria; Lobariella crenulata, L. pallidocrenulata, } \\
\text { Lobariella sp., Pseudocyphellaria sp., Ricasolia } \\
\text { amplissima, Sticta canariensis, S. neopulmonaria } \\
\text { (Lobariaceae); Megalospora sulphurata } \\
\text { (Megalosporaceae); Chaenothecopsis consociata } \\
\text { (Mycocaliciaceae); Phlyctis argena (Phlyctidaceae); } \\
\text { Chaenotheca brunneola (Coniocybomycetes). }\end{array}$ & $\begin{array}{l}\text { Škaloud et al. (2016). All known photobionts } \\
\text { previously included in Dictyochloropsis s. lat. }\end{array}$ \\
\hline Symbiochloris sp. & $\begin{array}{l}\text { Sticta ainoae, S. cinereoglauca, S. granatensis, } \\
\text { S. laciniata, S. laciniosa, S. puracensis, Sticta spp. }\end{array}$ & Lindgren et al. (2020) \\
\hline \multicolumn{3}{|c|}{ Class Ulvophyceae, Order Trentepohliales } \\
\hline Cephaleuros sp. & Strigula smaragdula & Green (2012) \\
\hline Cephaleuros sp. & Strigula smaragdula & Jiang et al. (2020) \\
\hline Phycopeltis sp. & Tenuitholiascus porinoides & Jiang et al. (2020) \\
\hline Trentepohlia lagenifera & $\begin{array}{l}\text { Graphina cleistoblephara, G. inabensis, G. intortura, } \\
\text { G. mendax, G. undulata, Graphis aperiens, G. aphanes, } \\
\text { G. batanensis, G. cognata, G. connectans, G. dupaxana, } \\
\text { G. handelii, G. intricata, G. proserpens, G. rikuzensis, } \\
\text { G. rufla, G. scripta, G. subdura, G. subtropica, } \\
\text { G. subvirginea, G. tenella, Phaeographina } \\
\text { chlorocarpoides, P. endofusca, Phaeographis } \\
\text { asteriformis, P exaltata, P. pruinosa }\end{array}$ & Nakano (1988). id: LM, culture. \\
\hline T. lagenifera & Pyrenula japonica & Nakano \& Ihda (1996). id: LM, culture. \\
\hline Trentepohlia/‘Printzina’' & $\begin{array}{l}\text { Acanthothecis sp., Anthracothecium sp., Astrothelium } \\
\text { cinnamomeum, A. galbineum, A. leucoconicum, } \\
\text { A. versicolor, Astrothelium sp., Coenogonium linkii, } \\
\text { Cryptothecia assimilis, Cryptothelium pulchrum, } \\
\text { Cryptothelium sp., Dendrographa alectorioides, } \\
\text { Dichosporidium boschianum, Graphis scripta, Graphis } \\
\text { sp., Laurera megasperma, Myriotrema peninsulae, } \\
\text { Porina distans, P. dolichophora, P. imitatrix, P. nucula, } \\
\text { P. tetracerae, Porina spp., Racodium rupestre, } \\
\text { Thalloloma hypoleptum, Thelotrema pachysporum, } \\
\text { Trypethelium aenum, T. nitidiusculum, Trypethelium spp. }\end{array}$ & $\begin{array}{l}\text { Nelsen et al. (2011). 'Printzina' clades occur scattered } \\
\text { throughout Trentepohlia. } \\
\text { Mycobionts represent Arthoniomycetes, } \\
\text { Dothideomycetes and Lecanoromycetes. }\end{array}$ \\
\hline
\end{tabular}


Table 1. (Continued)

\begin{tabular}{|c|c|c|}
\hline Alga & Fungal symbionts & References \& comments \\
\hline Trentepohlia/'Printzina’' & $\begin{array}{l}\text { Astrothelium variolosum, Graphis endoxantha, } \\
\text { G. pulverulenta, G. scripta, Herpothallon rubrocinctum, } \\
\text { Phaeographina sp., Phaeographis inusta, P. punctiformis, } \\
\text { Pyrenula confinis, P. cruenta, P. pseudobufonia, } \\
\text { P. sexlocularis, Strigula subtilissima, Trypethelium virens }\end{array}$ & Green (2012). Photobiont of one Strigula sp. included. \\
\hline Trentepohlia 'Printzina' & $\begin{array}{l}\text { Acrocordia gemmata, Arthonia cinnabarina, A. radiata, } \\
\text { Arthothelium ruanum, Cystocoleus ebeneus, Dimerella } \\
\text { pineti, Graphis propinqua, G. scripta, G. submarginata, } \\
\text { Gyalecta jenensis, Mycoporum sparsellum, Opegrapha } \\
\text { atra, Pyrenula laevegata, Roccella decipiens, } \\
\text { R. galapagoensis, R. linearis, R. lirellina, R. maderensis, } \\
\text { R. cf. montagnei, R. phycopsis, R. tinctoria, } \\
\text { R. tuberculata; Thelotrema lepadinum }\end{array}$ & Hametner et al. $(2014 a, b)$ \\
\hline Trentepohlia sp. & Lecanographa amylacea & $\begin{array}{l}\text { Ertz et al. (2018). Mycobiont also forms } \\
\text { heteromorphic, asexual thalli with Trebouxia sp.! }\end{array}$ \\
\hline Trentepohlia sp. & $\begin{array}{l}\text { Dichosporidium sp., Diorygma antillarum, D. confluens, } \\
\text { D. nigrocinctum, Diorygma sp., Herpothallon echinatum, } \\
\text { H. rubroechinatum, Herpothallon sp., Ocellularia } \\
\text { sorediigera, Ocellularia spp., Porina sp., Sagenidiopsis } \\
\text { isidiata, Sagenidiopsis sp., Syncesia farinacea }\end{array}$ & Kosecka et al. (2020) \\
\hline \multicolumn{3}{|l|}{ Class Ulvophyceae, Order Ulvales } \\
\hline Blidingia minima & Turgidosculum ulvae & $\begin{array}{l}\text { Pérez-Ortega et al. (2018). Form 'borderline lichen' but } \\
\text { mycobiont belongs to lichen-forming clade. }\end{array}$ \\
\hline (Dilabifilum) & Hydropunctaria adriatica & Tschermak-Woess (1976). id: LM, culture. \\
\hline (Dilabifilum) & $\begin{array}{l}\text { Hydropunctaria maura, } H \text {. rheitrophila, Wahlenbergiella } \\
\text { striatula, Verrucaria aquatilis }\end{array}$ & Thüs et al. (2011) \\
\hline (Dilabifilum) & Verrucaria glaucina & Voytsekhovich \& Beck (2016). id: LM. \\
\hline Halofilum ramosum & $\begin{array}{l}\text { Hydropunctaria amphibia, H. maura, Wahlenbergiella } \\
\text { striatula }\end{array}$ & Darienko \& Pröschold (2017); Gasulla et al. (2019). \\
\hline Lithotrichon pulchrum & Hydropunctaria rheitrophila & Darienko \& Pröschold (2017). Submerged lichen. \\
\hline Paulbroadya petersii & Wahlenbergiella mucosa & Darienko \& Pröschold (2017) \\
\hline Pseudendoclonium arthopyreniae & $\begin{array}{l}\text { Species of Caloplaca, Rinodina, Thelidium and } \\
\text { Verrucaria }\end{array}$ & $\begin{array}{l}\text { Watanabe et al. (1997). Maritime lichens. According to } \\
\text { Thüs et al. (2011), maritime specimens of Caloplaca } \\
\text { etc. may overgrow Verrucariaceae containing } \\
\text { Dilabifilum (Pseudendoclonium). id: LM, culture. }\end{array}$ \\
\hline P. incrustans & Verrucaria aquatilis & $\begin{array}{l}\text { Tschermak-Woess (1970). Dilabifilum, reclassified in } \\
\text { Darienko \& Pröschold (2017). }\end{array}$ \\
\hline P. commune & Hydropunctaria maura & Dilabifilum, reclassified in Darienko \& Pröschold (2017). \\
\hline \multicolumn{3}{|l|}{ Class Chlorophyceae } \\
\hline Bracteacoccus sp. & 'Multiclavula clara' [=Sulzbacheromyces sinensis] & Takeshita et al. (2010). id: LM, culture. \\
\hline Bracteacoccus sp. & Sulzbacheromyces caatingae & Hodkinson et al. (2014). rbcL sequences. \\
\hline Bracteacoccus sp. & Sulzbacheromyces sinensis & Masumoto (2020). ITS and rbcL sequences. \\
\hline Chlamydomonas sp. & Pyronema & Skuja (1943). Association doubtfully lichenic. \\
\hline Chlorosarcinopsis minor & Lecidea lapicida, L. plana & Plessl (1963). Genus polyphyletic (Neustupa 2015). \\
\hline Gloeocystis sp. & Bryophagus gloeocapsa, Epigloea bactrospora & $\begin{array}{l}\text { Tschermak-Woess (1988a). Gloeocystis s. lat. highly } \\
\text { polyphyletic (Neustupa 2015). }\end{array}$ \\
\hline Radiococcus signiensis & Placynthiella icmalea, P. uliginosa & $\begin{array}{l}\text { Voytsekhovich et al. (2011). Other photobionts found in } \\
\text { lesser abundance within same algal layer. id: LM, culture. }\end{array}$ \\
\hline Trochiscia sp. & Polyblastia amota, P. hyperborea & $\begin{array}{l}\text { Tschermak (1941b); Ahmadjian (1967); but Ettl \& } \\
\text { Gärtner (2014) consider ID questionable. }\end{array}$ \\
\hline \multicolumn{3}{|c|}{ Domain Eukarya, Eukaryote supergroup Archaeplastida, Kingdom Plantae, Division Streptophyta (Charophytes) } \\
\hline Interfilum sp. & Micarea prasina; Placynthiella icmalea, P. uliginosa & $\begin{array}{l}\text { Voytsekhovich et al. (2011). Reported as secondary } \\
\text { (less abundant) photobiont within algal layer. id: LM, } \\
\text { culture. }\end{array}$ \\
\hline
\end{tabular}


Table 1. (Continued)

\begin{tabular}{|c|c|c|}
\hline Alga & Fungal symbionts & References \& comments \\
\hline \multicolumn{3}{|l|}{ Class Xanthophyceae } \\
\hline Heterococcus sp. & Verrucaria funckii, V. laevata & Zeitler (1954); Tschermak-Woess (1988a). \\
\hline Heterococcus sp. & Hydropunctaria rheitrophila; Verrucaria funckii, V. hydrela & Thüs et al. (2011) \\
\hline Xanthonema sp. & Staurothele clopimoides & Pereira Riquelme (1992). id: LM. \\
\hline
\end{tabular}

Acknowledgements. The manuscript benefited from critical review by $\mathrm{Dr}$ Richard L. Moe and two anonymous referees, and the expert scrutiny of the journal production staff. Funding for colour in print was kindly provided by the College of Arts and Sciences and the Department of Biological Sciences, Florida Gulf Coast University.

Author ORCID. (D) William B. Sanders, 0000-0001-9572-4244.

\section{References}

Adams DG and Duggan PS (2002) Cyanobacteria-bryophyte symbioses. Journal of Experimental Botany 59, 1047-1058.

Adams DG, Duggan PS and Jackson O (2012) Cyanobacterial symbiosis. In Whitton BA (ed.), Ecology of Cyanobacteria II: Their Diversity in Space and Time. Heidelberg: Springer, pp. 593-647.

Ahmadjian V (1960) Some new and interesting species of Trebouxia, a lichenized alga. American Journal of Botany 47, 677-683.

Ahmadjian V (1962) Investigations on lichen synthesis. American Journal of Botany 49, 277-283.

Ahmadjian V (1967) A guide to the algae occurring as lichen symbionts: isolation, culture, cultural physiology, and identification. Phycologia 6, 127-160.

Ahmadjian V (1982) Holobionts have more parts. International Association for Lichenology Newsletter 15, 19.

Ahmadjian V (1987) Coevolution in lichens. Annals of the New York Academy of Sciences 503, 307-315.

Ahmadjian V (1988) The lichen alga Trebouxia: does it occur free-living? Plant Systematics and Evolution 158, 243-247.

Ahmadjian V (1993) The Lichen Symbiosis. New York: John Wiley and Sons.

Ahmadjian V (1995) Lichens are more important than you think. BioScience 45, 124.

Ahmadjian V (2001) Trebouxia: reflections on a perplexing and controversial lichen photobiont. In Seckbach J (ed.), Symbiosis: Mechanisms and Model Systems. Dordrecht: Kluwer Academic Publishers, pp. 373-383.

Ahmadjian V (2002) Lingering lichen myths are hard to dispel. ISS Symbiosis International 2, 1-2.

Ahmadjian V and Heikkilä H (1970) The culture and synthesis of Endocarpon pusillum and Staurothele clopima. Lichenologist 4, 259-267.

Ahmadjian A and Jacobs JB (1981) Relationship between fungus and alga in the lichen Cladonia cristatella Tuck. Nature 289, 169-172.

Ahmadjian A, Russell LA and Hildreth KC (1980) Artificial reestablishment of lichens. I. Morphological interactions between the phycobionts of different lichens and the mycobionts Cladonia cristatella and Lecanora chrysoleuca. Mycologia 72, 73-89.

Aoki M, Nakano T, Kanda H and Deguchi H (1998) Photobionts isolated from Antarctic lichens. Journal of Marine Biotechnology 6, 39-43.

Archibald PA (1975) Trebouxia de Puymaly (Chlorophyceae, Chlorococcales) and Pseudotrebouxia gen. nov. (Chlorophyceae, Chlorosarcinales). Phycologia 14, 125-137.

Armaleo D and Clerc P (1991) Lichen chimeras: DNA analysis suggests that one fungus forms two morphotypes. Experimental Mycology 15, 1-10.
Armaleo D, Müller O, Lutzoni F, Andrésson ÓS, Blanc G, Bode HB, Collart FR, Dal Grande F, Dietrich F, Grigoriev IV, et al. (2019) The lichen symbiosis re-viewed through the genomes of Cladonia grayi and its algal partner Asterochloris glomerata. BMC Genomics 20, 605.

Ascaso C, Valladares F and de los Ríos A (1995) New ultrastructural aspect of pyrenoids of the lichen photobiont Trebouxia (Microthamniales, Chlorophyta). Journal of Phycology 31, 114-119.

Asplund J and Wardle DA (2013) The impact of secondary compounds and functional characteristics on lichen palatability and decomposition. Journal of Ecology 101, 689-700.

Bačkor M, Peksa O, Škaloud P and Bačkorová M (2010) Photobiont diversity in lichens from metal-rich substrata based on ITS rDNA sequences. Ecotoxicology and Environmental Safety 73, 603-612.

Bates ST, Cropsey GWG, Caporaso JG, Knight R and Fierer N (2011) Bacterial communities associated with the lichen symbiosis. Applied and Environmental Microbiology 77, 1309-1314.

Beck A (1999) Photobiont inventory of a lichen community growing on heavy-metal-rich rock. Lichenologist 31, 501-510.

Beck A (2002) Selektivität der symbionten schwermetalltoleranter flechten. Ph.D. thesis, Ludwig Maximilian University of Munich.

Beck A and Koop H-U (2001) Analysis of the photobiont population in lichens using a single-cell manipulator. Symbiosis 31, 57-67.

Beck A and Mayr C (2012) Nitrogen and carbon isotope variability in the green-algal lichen Xanthoria parietina and their implications on mycobiont-photobiont interactions. Ecology and Evolution 2, 3132-3144.

Beck A, Friedl T and Rambold G (1998) Selectivity of photobiont choice in a defined lichen community: inferences from cultural and molecular studies. New Phytologist 139, 709-720.

Beck A, Kasalicky T and Rambold G (2002) Myco-photobiontal selection in a Mediterranean cryptogam community with Fulgensia fulgida. New Phytologist 153, 317-326.

Beck A, Bechteler J, Casanova-Katny A and Dzhilyanova I (2019) The pioneer lichen Placopsis in maritime Antarctica: genetic diversity of their mycobionts and green algal symbionts, and their correlation with deglaciation time. Symbiosis 79, 1-24.

Beckett RP, Solhaug KA, Gauslaa Y and Minibayeva F (2019) Improved photoprotection in melanized lichens is a result of fungal solar radiation screening rather than photobiont acclimation. Lichenologist 51, 483-491.

Bergman B and Hällbom L (1981) Nostoc of Peltigera canina when lichenized and isolated. Canadian Journal of Botany 60, 2092-2098.

Bergman B, Johanssen C and Söderbäck E (1992) The Nostoc-Gunnera symbiosis (Tansley Review No. 42). New Phytologist 122, 379-400.

Bertsch A and Butin H (1967) Die Kultur der Erdflechte Endocarpon pusillum im Labor. Planta 72, 29-42.

Bhâradwâja Y (1933) False branching and sheath structure in the Myxophyceae, with special reference to the Scytonemataceae. Archiv für Protistenkunde 81, 243-283.

Bitter G (1904) Peltigeren-Studien II. Das Verhalten der oberseitigen Thallusschuppen der Peltigera lepidophora (Nyl). Berichte der Deutschen Botanischen Gesellschaft 22, 251-254. 
Blaha J, Baloch E and Grube M (2006) High photobiont diversity associated with the euryoecious lichen-forming ascomycete Lecanora rupicola (Lecanoraceae, Ascomycota). Biological Journal of the Linnean Society 88, 283-293.

Boch S, Prati D, Werth S, Rüetschi J and Fischer M (2011) Lichen endozoochory by snails. PLoS ONE 6, e18770.

Bock C, Krienitz L and Pröschold T (2011) Taxonomic reassessment of the genus Chlorella (Trebouxiophyceae) using molecular signatures (barcodes), including description of seven new species. Fottea 11, 293-312.

Boissière J-C, Boissière M-C, Champion-Arnaud P, Lallmant $\mathrm{R}$ and Wagner J (1987) Le cycle des Nostoc des genres Peltigera et Collema en cultures in vitro et dans le thalle liquénique. Canadian Journal of Botany 65, 1468-1477.

Bold HC and Wynne M (1985) Introduction to the Algae, 2nd Edn. Englewood Cliffs, New Jersey: Prentice Hall.

Bornet E (1873) Recherches sur les gonidies des algues. Annales des Sciences Naturelles (5me Série, Botanique) 17, 45-110.

Brito A, Vieira J, Vieira CP, Zhu T, Leão PN, Ramos V, Lu X, Vasconcelos VM, Gugger M and Tamagnini P (2020) Comparative genomics discloses the uniqueness and the biosynthetic potential of the marine cyanobacterium Hyella patelloides. Frontiers in Microbiology 11, 1527.

Brodo IM and Richardson DHS (1978) Chimeroid association in the genus Peltigera. Lichenologist 10, 157-170.

Brodo IM, Sharnoff SD and Sharnoff S (2001) Lichens of North America. New Haven and London: Yale University Press.

Brooks F, Rindi F, Suto S, Ohtani S and Green M (2015) The Trentepohliales (Ulvophyceae, Chlorophyta): an unusual algal order and its novel plant pathogen, Cephaleuros. Plant Disease 99, 740-753.

Brunner U and Honegger R (1985) Chemical and ultrastructural studies on the distribution of sporopollenin-like biopolymers in six genera of lichen phycobionts. Canadian Journal of Botany 63, 2221-2230.

Bubrick P (1988) Effects of symbiosis on the photobiont. In Galun M (ed.), CRC Handbook of Lichenology. Boca Raton, Florida: CRC Press, pp. 133-144.

Bubrick P, Galun M and Frensdorff A (1984) Observations on free-living Trebouxia de Puymaly and Pseudotrebouxia Archibald, and evidence that both symbionts from Xanthoria parietina (L.) Th. Fr. can be found freeliving in nature. New Phytologist 97, 455-462.

Büdel B (1985) Blue-green phycobionts in the lichen family Lichinaceae. Archiv für Hydrobiologie, Supplement 71 [Algological Studies 38/39], 355-357.

Büdel B (1999) Ecology and diversity of rock-inhabiting cyanobacteria in tropical regions. European Journal of Phycology 34, 361-370.

Büdel B and Henssen A (1983) Chroococcidiopsis (Cyanophyceae), a phycobiont in the lichen family Lichinaceae. Phycologia 22, 367-375.

Büdel B and Henssen A (1987) Trebouxia aggregata und Gloeocapsa sanguinea, phycobionten in Euopsis granatina (Lichinaceae). Plant Systematics and Evolution 158, 235-241.

Büdel B and Kauff F (2012) Blue-green algae. In Frey G (series ed.), Syllabus of Plant Families: Adolf Engler's Syllabus der Pflanzenfamilien, Part VI. Stuttgart: Borntraeger Verlagsbuchhandlung, pp. 5-39.

Butler RD and Allsopp A (1972) Ultrastructural investigations in the Stigonemataceae (Cyanophyta). Archiv für Mikrobiologie 82, 283-299.

Canals A, Hernández-Mariné M, Gómez-Bolea A and Llimona X (1997) Botryolepraria, a new monotypic genus segregated from Lepraria. Lichenologist 29, 339-345.

Candotto Carniel F, Zanelli D, Bertuzzi S and Tretiach M (2015) Desiccation tolerance and lichenization: a case study with the aeroterrestrial microalga Trebouxia sp. (Chlorophyta). Planta 242, 493-505.

Cao S, Zhang F, Liu C, Hao Z, Tian Y, Zhu L and Zhou Q (2015) Distribution patterns of haplotypes for symbionts from Umbilicaria esculenta and $U$. muehlenbergii reflect the importance of reproductive strategy in shaping population genetic structure. BMC Microbiology 15, 212.

Cao S, Zhang F, Zheng H, Peng F, Liu C and Zhou Q (2018) Coccomyxa greatwallensis sp. nov. (Trebouxiophyceae, Chlorophyta), a lichen epiphytic alga from Fildes Peninsula, Antarctica. PhytoKeys 110, 39-50.

Cardós JLH, Prieto M, Jylhä M, Aragón G, Molina MC, Martínez I and Rikkinen J (2019) A case study on the re-establishment of the cyanolichen symbiosis: where do the compatible photobionts come from? Annals of Botany 124, 379-388.
Casano LM, del Campo E, García-Breijo FJ, Reig-Armiñana J, Gasulla F, del Hoyo A, Guéra A and Barreno E (2011) Two Trebouxia algae with different physiological performances are ever-present in lichen thalli of Ramalina farinacea. Coexistence versus competition? Environmental Microbiology 13, 806-818.

Catalá S, del Campo EM, Barreno E, García-Breijo FJ, Reig-Armiñana J and Casano LM (2016) Coordinated ultrastructural and phylogenomic analyses shed light on the hidden phycobiont diversity of Trebouxia microalgae in Ramalina fraxinea. Molecular Phylogenetics and Evolution 94, 765-777.

Chen L, Zhang L and Liu T (2016) Concurrent production of carotenoids and lipid by a filamentous microalga Trentepohlia arborum. Bioresource Technology 214, 567-573.

Chodat R (1913) Monographie d'algues en culture pure. Matériaux por la Flore Cryptogamique Suisse [Beiträge zur Kryptogamenflora der Schweiz] 4, 1-226.

Clayden SR (1998) Thallus initiation and development in the lichen Rhizocarpon lecanorinum. New Phytologist 139, 685-695.

Collins CR and Farrar JF (1978) Structural resistances to mass transfer in the lichen Xanthoria parietina. New Phytologist 81, 71-83.

Coppins BJ (1983) A taxonomic study of the lichen genus Micarea in Europe. Bulletin of the British Museum (Natural History), Botany Series 11, 17-214.

Cordeiro LM, Reis RA, Cruz LM, Stocker-Wörgötter E, Grube M and Iacomini M (2005) Molecular studies of photobionts of selected lichens from the coastal vegetation of Brazil. FEMS Microbiology Ecology 54, 381-390.

Cornejo C and Scheidegger C (2013) New morphological aspects of cephalodium formation in the lichen Lobaria pulmonaria (Lecanorales Ascomycota). Lichenologist 45, 77-87.

Cornejo C and Scheidegger C (2016) Cyanobacterial gardens: the liverwort Frullania asagrayana acts as a reservoir of lichen photobionts. Environmental Microbiology Reports 8, 352-357.

Cornejo C, Nelson PR, Stepanchikova I, Himelbrant D, Jørgensen P-M and Scheidegger C (2016) Contrasting pattern of photobiont diversity in the Atlantic and Pacific populations of Erioderma pedicellatum (Pannariaceae). Lichenologist 48, 275-291.

Costa J-L and Lindblad P (2002) Cyanobacteria in symbiosis with cycads. In Rai AN, Bergman B and Rasmussen U (eds), Cyanobacteria in Symbiosis. Dordrecht: Kluwer Academic Publishers, pp. 195-205.

Crittenden P, David JC, Hawksworth DL and Campbell FS (1995) Attempted isolation and success in the culturing of a broad spectrum of lichen-forming and lichenicolous fungi. New Phytologist 130, 267-297.

Czeczuga B and Maximov OM (1996) Carotenoids in the cells of the alga Trentepohlia gobii Meyer. Acta Societatis Botanicorum Poloniae 65, 273-276.

Dahlkild A, Kallersjö M, Lohtander K and Tehler A (2001) Photobiont diversity in the Physciaceae (Lecanorales). Bryologist 104, 527-536.

Dal Forno M, Lawrey JD, Sikaroodi M, Gillevet PM, Schuettpelz E and Lücking R (2020) Extensive photobiont sharing in a rapidly radiating cyanolichen clade. Molecular Ecology 30, 1755-1776.

Dal Grande F, Widmer I, Wagner HH and Scheidegger C (2012) Vertical and horizontal photobiont transmission within populations of a lichen symbiosis. Molecular Ecology 21, 3159-3172.

Dal Grande F, Alors D, Divakar PK, Bálint M, Crespo A and Schmitt I (2014a) Insights into intrathalline genetic diversity of the cosmopolitan lichen symbiotic green alga Trebouxia decolorans Ahmadjian using microsatellite markers. Molecular Phylogenetics and Evolution 72, 54-60.

Dal Grande F, Beck A, Cornejo C, Singh G, Cheenacharoen S, Nelsen MP and Scheidegger C (2014b) Molecular phylogeny and symbiotic selectivity of the green algal genus Dictyochloropsis s. 1. (Trebouxiophyceae): a polyphyletic and widespread group forming photobiont-mediated guilds in the lichen family Lobariaceae. New Phytologist 202, 455-470.

Dal Grande F, Rolshausen G, Divakar PK, Crespo A, Otte J, Schleuning M and Schmitt I (2018) Environment and host identity structure communities of green algal symbionts in lichens. New Phytologist 217, 277-289.

Darienko T and Pröschold T (2015) Genetic variability and taxonomic revision of the genus Auxenochlorella (Shihira et Krauss) Kalina et Puncocharova (Trebouxiophyceae, Chlorophyta). Journal of Phycology 51, 394-400.

Darienko T and Pröschold T (2017) Toward a monograph of non-marine Ulvophyceae using an integrative approach (Molecular phylogeny and systematics of terrestrial Ulvophyceae II.). Phytotaxa 324, 1-41. 
Darienko T and Pröschold T (2019) The genus Jaagichlorella Reisigl (Trebouxiophyceae, Chlorophyta) and its close relatives: an evolutionary puzzle. Phytotaxa 388, 47-68.

Darienko T, Gustavs L, Mudimu O, Menendez CR, Schumann R, Karsten U, Friedl T and Pröschold T (2010) Chloroidium, a common terrestrial coccoid green alga previously assigned to Chlorella (Trebouxiophyceae, Chlorophyta). European Journal of Phycology 45, 79-95.

Darienko T, Gruber M, Pröschold T and Schagerl M (2013) Terrestrial microalgae on Viennese buildings. Final report of project H-2081/2010. Vienna: Universität Wien.

Darienko T, Gustavs L, Eggert A, Wolf W and Pröschold T (2015) Evaluating the species boundaries of green microalgae (Coccomyxa, Trebouxiophyceae, Chlorophyta) using integrative taxonomy and DNA barcoding with further implications for the species identification in environmental samples. PLoS ONE 10, e0127838.

Darienko T, Gustavs L and Pröschold T (2016) Species concept and nomenclatural changes within the genera Elliptochloris and Pseudochlorella (Trebouxiophyceae) based on an integrative approach. Journal of Phycology 52, 1125-1145.

Darienko T, Lukešová A and Pröschold T (2018) The polyphasic approach revealed new species of Chloroidium (Trebouxiophyceae, Chlorophyta). Phytotaxa 372, 51-66.

de los Ríos A, Sancho LG, Grube M, Wierzchos J and Ascaso C (2005) Endolithic growth of two Lecidea lichens in granite from continental Antarctica detected by molecular and microscopy techniques. New Phytologist 165, 181-190.

de los Ríos A, Raggio J, Pérez-Ortega S, Vivas M, Pintado A, Green TGA, Ascaso C and Sancho LG (2011) Anatomical, morphological and ecophysiological strategies in Placopsis pycnotheca (lichenized fungi, Ascomycota) allowing rapid colonization of recently deglaciated soils. Flora 206, 857-864.

Degelius G (1964) Biological studies of the epiphytic vegetation on twigs of Fraxinus excelsior. Acta Horti Gotoburgensis 27, 11-55.

Delwiche CF (1999) Tracing the thread of plastid diversity through the tapestry of time. American Naturalist 154, S164-S177.

Döbbler P (1984) Symbiosen zwischen Gallertalgen und Gallertpilzen der Gattung Epigloea (Ascomycetes). Beiheft zur Nova Hedwigia 79, 203-239.

Dodds WK, Gudder DA and Mollenhauer D (1995) The ecology of Nostoc. Journal of Phycology 31, 2-18.

Doering JA, Booth T, Wiersma YF and Piercey-Normore MD (2020) How do genes flow? Identifying potential dispersal mode for the semi-aquatic lichen Dermatocarpon luridum using spatial modelling and photobiont markers. BMC Ecology 20, 56.

Doering M and Piercey-Normore MD (2009) Genetically divergent algae shape an epiphytic lichen community on Jack Pine in Manitoba. Lichenologist 41, 69-80.

Drew EA and Smith DC (1967) Studies in the physiology of lichens VII. The physiology of the Nostoc symbiont of Peltigera polydactyla compared with cultured and free-living forms. New Phytologist 66, 379-388.

Eliáš M, Neustupa J, Pažoutová $\mathbf{M}$ and Škaloud P (2013) A case of taxonomic inflation in coccoid algae: Ellipsoidion parvum and Neocystis vischeri are conspecific with Neocystis (=Nephrodiella) brevis (Chlorophyta, Trebouxiophyceae). Phytotaxa 76, 15-27.

Elshobary ME, Osman MEH, Abushady AM and Piercey-Normore MD (2015) Comparison of lichen-forming cyanobacterial and green algal photobionts with free-living algae. Cryptogamie, Algologie 36, 81-100.

Elvebakk A, Papaefthimiou D, Robertsen EH and Liaimer A (2008) Phylogenetic patterns among Nostoc cyanobionts within bi- and tripartite lichens of the genus Pannaria. Journal of Phycology 44, 1049-1059.

Engelen A, Convey P and Ott S (2010) Life history strategy of Lepraria borealis at an Antarctic inland site, Coal Nunatak. Lichenologist 42, 339-346.

Engelen A, Convey P, Popa $\mathbf{O}$ and Ott S (2016) Lichen photobiont diversity and selectivity at the southern limit of the maritime Antarctic region (Coal Nunatak, Alexander Island). Polar Biology 39, 2403-2410.

Ertz D, Guzow-Krzemińska B, Thor G, Łubek A and Kukwa M (2018) Photobiont switching causes changes in the reproduction strategy and phenotypic dimorphism in the Arthoniomycetes. Scientific Reports 8, 4952.
Ettl H and Gärtner G (2014) Syllabus der Boden-, Luft-, und Flechtenalgen, 2nd Edn. Berlin and Heidelberg: Springer Spektrum.

Feige GB, Lumbsch HT and Mies B (1993) Morphological and chemical changes in Roccella thalli infected by Lecanactis grumulosa. Cryptogamic Botany 3, 101-107.

Fernández-Marín B, López-Pozo $M$, Perera-Castro AV, Irati Arzac $M$, Sáenz-Ceniceros A, Colesie C, de los Ríos A, Sancho LG, Pintado A, Laza JM, et al. (2019) Symbiosis at its limits: ecophysiological consequences of lichenization in the genus Prasiola in Antarctica. Annals of Botany 124, 1211-1226.

Fernández-Mendoza F, Domaschke S, García MA, Jordan P, Martín MP and Printzen C (2011) Population structure of mycobionts and photobionts of the widespread lichen Cetraria aculeata. Molecular Ecology 20, 1208-1232.

Fewer D, Friedl T and Büdel B (2002) Chroococcidiopsis and heterocystdifferentiating cyanobacteria are each other's closest living relatives. Molecular Phylogenetics and Evolution 23, 82-90.

Fiore MF, Sant'Anna CL, Azevedo MTDP, Komárek J, Kaštovský J, Sulek J and Lorenzi AAS (2007) The cyanobacterial genus Brasilonema, gen. nov., a molecular and phenotypic evaluation. Journal of Phycology 43, 789-798.

Fisher KA and Lang NJ (1971) Comparative ultrastructure of cultured species of Trebouxia. Journal of Phycology 7, 155-165.

Flechtner VR, Johansen JR and Belnap J (2009) The biological soil crusts of the San Nicolas Island: enigmatic algae from a geographically isolated ecosystem. Western North American Naturalist 68, 405-436.

Fontaine KM, Beck A, Stocker-Wörgötter E and Piercey-Normore MD (2012) Photobiont relationships and phylogenetic history of Dermatocarpon luridum var. luridum and related Dermatocarpon species. Plants 1, 39-60.

Forsberg A and Lindblad P (1996) The Ophrydium-Chlorella (Chlorophyceae, Chlorophyta) symbiosis: an ultrastructural characterization. Phycologia 35, 44-47.

Francisco de Oliveira PM, Timsina B and Piercey-Normore MD (2012) Diversity of Ramalina sinensis and its photobiont in local populations. Lichenologist 44, 649-660.

Friedl T (1987) Thallus development and phycobionts of the parasitic lichen Diploschistes muscorum. Lichenologist 19, 183-191.

Friedl T (1989) Comparative ultrastructure of pyrenoids in Trebouxia (Microthamniales, Chlorophyta). Plant Systematics and Evolution 164, 145-159.

Friedl T (1995) Inferring taxonomic positions and testing genus level assignments in coccoid green lichen algae: a phylogenetic analysis of $18 \mathrm{~S}$ ribosomal RNA sequences from Dictyochloropsis reticulata and from members of the genus Myrmecia (Chlorophyta, Trebouxiophyceae cl. nov.). Journal of Phycology 31, 632-639.

Friedl T (1996) Evolution of the polyphyletic genus Pleurastrum (Chlorophyta): inferences from nuclear-encoded ribosomal DNA sequences and motile cell ultrastructure. Phycologia 35, 456-469.

Friedl T and Büdel B (2008) Photobionts. In Nash, TH III (ed.), Lichen Biology. New York: Cambridge University Press, pp. 9-26.

Fritsch FE (1945) The Structure and Reproduction of the Algae, Vol. II. Cambridge: Cambridge University Press.

Fröberg L, Björn LO, Baur A and Baur B (2001) Viability of lichen photobionts after passing through the digestive tract of a land snail. Lichenologist 33, 543-545.

Fučíková K, Lewis PO and Lewis LA (2014) Putting incertae sedis taxa in their place: a proposal for ten new families and three new genera in Sphaeropleales (Chlorophyceae, Chlorophyta). Journal of Phycology 50, 14-25.

Fučíková K, Lewis PO, Neupane S, Karol KG and Lewis LA (2019) Order, please! Uncertainty in the ordinal-level classification of Chlorophyceae. PeerJ 7, e6899.

Gagunashvili AN and Andrésson ÓS (2018) Distinctive characters of Nostoc genomes in cyanolichens. BMC Genomics 19, 434.

Galløe O $(1927,1932)$ Natural History of the Danish Lichens, Parts I and V. Copenhagen: H. Aschehoug and Co, Levin \& Munksgaard.

Gallun [sic] M, Ben-Shaul Y and Paran N (1971) The fungus-alga association in the Lecideaceae: an ultrastructural study. New Phytologist 70, 483-485.

Galun M, Paran N and Ben-Shaul Y (1970) The fungus-alga association in the Lecanoraceae: an ultrastructural study. New Phytologist 69, 599-603. 
Garbary DJ and London JF (1995) The Ascophyllum/Polysiphonial Mycosphaerella symbiosis. V. Fungal infection protects A. nodosum from desiccation. Botanica Marina 38, 529-533.

Garbary DJ and MacDonald KA (1995) The Ascophyllum/Polysiphonial Mycosphaerella symbiosis. IV. Mutualism in the Ascophyllum/ Mycosphaerella interaction. Botanica Marina 38, 221-225.

Garcia-Pichel F (2009) Cyanobacteria. In Schaechter M (ed.), Encyclopedia of Microbiology, Vol. 2, 3rd Edn. Oxford and San Diego: Elsevier [Academic Press], pp. 107-124.

Garrido-Benavent I, Pérez-Ortega S and de los Ríos A (2017) From Alaska to Antarctica: species boundaries and genetic diversity of Prasiola (Trebouxiophyceae), a foliose chlorophyte associated with the bipolar lichen-forming fungus Mastodia tessellata. Molecular Phylogenetics and Evolution 107, 117-131.

Garrido-Benavent I, de los Ríos A, Fernández-Mendoza F and PérezOrtega S (2018) No need for stepping stones: direct, joint dispersal of the lichen-forming fungus Mastodia tesselata (Ascomycota) and its photobiont explains their bipolar distribution. Journal of Biogeography 45, 213-224.

Garrido-Benavent I, Pérez-Ortega S, de los Ríos A and Fernández-Mendoza F (2020) Amphitropical variation of the algal partners of Pseudephebe (Parmeliaceae, lichenized fungi). Symbiosis 82, 35-48.

Gärtner G (1985) Die Gattung Trebouxia Puymaly (Chlorellales, Chlorophyceae). Archiv für Hydrobiologie, Supplement 71 [Algological Studies 41], 495-548.

Gärtner G and Ingolić E (1989) Ein Beitrag zur Kenntnis von Apatococcus lobatus (Chlorophyta, Chaetophorales, Leptosiroideae). Plant Systematics and Evolution 164, 133-143.

Garty J and Delarea J (1988) Evidence of liberation of lichen ascospores in clusters and reports on contact between free-living algal cells and germinating lichen ascospores under natural conditions. Canadian Journal of Botany 66, 2171-2177.

Gasulla F, Guéra A, de los Ríos A and Pérez-Ortega S (2019) Differential responses to salt concentrations of lichen photobiont strains isolated from lichens occurring in different littoral zones. Plant and Fungal Systematics 64, 149-162.

Gasulla F, Barrasa JM, Casano LM and del Campo EM (2020) Symbiont composition of the basidiolichen Lichenomphalia meridionalis varies with altitude in the Iberian Peninsula. Lichenologist 52, 17-26.

Gauslaa Y, Alam MA, Lucas P-L, Chowdhury DP and Solhaug KA (2017) Fungal tissue per se is stronger as a UV-B screen than secondary fungal extrolites in Lobaria pulmonaria. Fungal Ecology 26, 109-113.

Geitler L (1933) Beiträge zur Kenntnis de Flechtensymbiose. I-III. Archiv für Protistenkunde 80, 378-409.

Geitler L (1934) Beiträge zur Kenntnis de Flechtensymbiose. IV, V. Archiv für Protistenkunde 82, 51-85.

Geitler L (1955) Clavaria mucida, eine extratropische Basidiolichene. Biologisches Zentralblatt 74, 145-159.

Giddings TH, Jr, and Staehelin LA (1981) Observations of microplasmodesmata in both heterocyst-forming and non-heterocyst forming filamentous cyanobacteria by freeze-fracture electron microscopy. Archives of Microbiology 129, 295-298.

González MA, Pröschold T, Palacios Y, Aguayo P, Inostroza I and Gómez PI (2013) Taxonomic identification and lipid production of two Chilean Chlorella-like strains isolated from a marine and an estuarine coastal environment. AoB PLANTS 5, plt020.

Good BH and Chapman RL (1978) The ultrastructure of Phycopeltis (Chroolepidaceae: Chlorophyta). I. Sporopollenin in the cell walls. American Journal of Botany 65, 27-33.

Graham LE, Graham JM and Wilcox LW (2009) Algae, 2nd Edn. San Francisco: Pearson Education Inc.

Green MS (2012) The Trentepohliales (Ulvophyceae, Chlorophyta) from coastal South Carolina. Ph.D. thesis, Tennessee Technological University.

Green TGA, Büdel B, Heber U, Meyer A, Zellner H and Lange OL (1993) Differences in photosynthetic performance between cyanobacterial and green algal components of lichen photosymbiodemes measured in the field. New Phytologist 125, 723-731.

Green TGA, Schlensog M, Sancho LG, Winkler JB, Broom FD and Schroeter B (2002) The photobiont determines the pattern of photosynthetic activity within a single lichen thallus containing cyanobacterial and green algal sectors (photosymbiodeme). Oecologia 130, 191-198.

Greenhalgh GN and Anglesea D (1979) The distribution of algal cells in lichen thalli. Lichenologist 11, 283-292.

Grube M and Berg B (2009) Microbial consortia of bacteria and fungi with focus on the lichen symbiosis. Fungal Biology Reviews 23, 72-85.

Grube $\mathbf{M}$ and Lücking R (2002) Fine structure of foliicolous lichens and their lichenicolous fungi studied by epifluorescence. Symbiosis 32, 229-246.

Grube M, Cernava T, Soh J, Fuchs S, Aschenbrenner I, Lassek C, Wegner U, Becher D, Riedel K, Sensen CW, et al. (2015) Exploring functional contexts of symbiotic sustain within lichen-associated bacteria by comparative omics. ISME Journal 9, 412-424.

Grube M, Muggia L, Baloch E, Hametner C and Stocker-Wörgötter E (2017a) Symbiosis of lichen-forming fungi with trentepohlialean algae. In Grube M, Seckbach J and Muggia L (eds), Algal and Cyanobacterial Symbioses. London: World Scientific Publishing Europe Ltd, pp. 85-110.

Grube M, Seckbach J and Muggia L (2017b) Algal and Cyanobacterial Symbioses. London: World Scientific Publishing Europe Ltd.

Gueidan C, Thüs H and Pérez-Ortega S (2011) Phylogenetic position of the brown algae-associated lichenized fungus Verrucaria tavaresiae (Verrucariaceae). Bryologist 114, 563-569.

Gustavs L, Eggert A, Michalik D and Karsten U (2010) Physiological and biochemical responses of green microalgae from different habitats to osmotic and matric stress. Protoplasma 243, 3-14.

Gustavs L, Görs M and Karsten U (2011) Polyol patterns in biofilm-forming aeroterrestrial green algae (Trebouxiophyceae, Chlorophyta). Journal of Phycology 47, 533-537.

Gustavs L, Schumann R and Karsten U (2016) Mixotrophy in the terrestrial green alga Apatococcus lobatus (Trebouxiophyceae, Chlorophyta). Journal of Phycology 52, 311-314.

Gustavs L, Schiefelbein U and Darienko T (2017) Symbioses of the green algal genera Coccomyxa and Elliptochloris (Trebouxiophyceae, Chlorophyta). In Grube M, Seckbach J and Muggia L (eds), Algal and Cyanobacterial Symbioses. London: World Scientific Publishing Europe Ltd, pp. 169-208.

Guzow-Krzemińska B (2006) Photobiont flexibility in the lichen Protoparmeliopsis muralis as revealed by ITS rDNA analyses. Lichenologist 38, 469-476.

Hallmann C, Stannek L, Fritzlar D, Hause-Reitner D, Friedl T and Hoppert M (2013) Molecular diversity of phototrophic biofilms on building stone. FEMS Microbiology Ecology 84, 355-372.

Hallmann C, Hoppert M, Mudimu O and Friedl T (2016) Biodiversity of green algae covering artificial hard substrate surfaces in a suburban environment: a case study using molecular approaches. Journal of Phycology 52, 732-744.

Hametner C, Stocker-Wörgötter E and Grube M (2014a) New insights into diversity and selectivity of trentepohlialean lichen photobionts from the extratropics. Symbiosis 63, 31-40.

Hametner C, Stocker-Wörgötter E, Rindi F and Grube M (2014b) Phylogenetic position and morphology of lichenized Trentepohliales (Ulvophyceae, Chlorophyta) from selected species of Graphidaceae. Phycological Research 62, 170-186.

Handa S, Ohmura Y, Nakano T and Nakahara-Tsubota M (2007) Airborne green microalgae (Chlorophyta) in snowfall. Hikobia 15, 109-120 [In Japanese, with English abstract and figure legends].

Hauck M, Helms G and Friedl T (2007) Photobiont selectivity in the epiphytic lichens Hypogymnia physodes and Lecanora conizaeoides. Lichenologist 39, 195-204.

Hawksworth DL (1988) The variety of fungal-algal symbioses, their evolutionary significance, and the nature of lichens. Botanical Journal of the Linnean Society 96, 3-20.

Hawksworth DL, Coppins BJ and James PW (1979) Blarneya, a lichenized hyphomycete from southern Ireland. Botanical Journal of the Linnean Society 79, 357-367.

Helms G, Friedl T, Rambold G and Mayrhofer H (2001) Identification of photobionts from the lichen family Physciaceae using algal-specific ITS rDNA sequencing. Lichenologist 33, 73-86.

Henley WJ, Hironaka JL, Gillou L, Buchheim MA, Buchheim JA, Fawley MW and Fawley KP (2004) Phylogenetic analysis of the 'Nannochloris- 
like' algae and diagnoses of Picochlorum oklahomensis gen. et sp. nov. (Trebouxiophyceae, Chlorophyta). Phycologia 43, 641-652.

Henskens FL, Green TGA and Wilkins A (2012) Cyanolichens can have both cyanobacteria and green algae in a common layer as major contributors to photosynthesis. Annals of Botany 110, 555-563.

Henson BJ, Watson LE and Barnum SR (2002) Molecular differentiation of the heterocystous cyanobacteria, Nostoc and Anabaena, based on complete NifD sequences. Current Microbiology 45, 161-164.

Henssen A (1981) Hyphomorpha als Phycobiont in Flechten. Plant Systematics and Evolution 137, 139-143.

Henssen A (1990) Thermutopsis jamesii, a new member of the Lichinaceae from Antigua. Lichenologist 22, 253-259.

Henssen A (1994) Contribution to the morphology and species delimitation in Heppia sensu stricto (lichenized Ascomycotina). Acta Botanica Fennica 150, 57-73.

Henssen A (1995) Studies on the biology and structure of Dacampia (Dothideales), a genus with lichenized and lichenicolous species. Cryptogamic Botany 5, 149-158.

Henssen A and Jahns HM (1974) Lichenes: Eine Einführung in die Flechtenkunde. Stuttgart: Georg Thieme.

Hessler R and Peveling E (1978) Die Lokalisation von ${ }^{14} \mathrm{C}$-Assimilaten in Flechtenthalli von Cladonia incrassata Floerke und Hypogymnia physodes (L.) Ach. Zeitschrift für Pflanzenphysiologie 86, 287-302.

Hestmark G, Lutzoni F and Miadlikowska J (2016) Photobiont associations in co-occurring umbilicate lichens with contrasting modes of reproduction in coastal Norway. Lichenologist 48, 545-557.

Hill DJ (1972) The movement of carbohydrate from the alga to the fungus in the lichen Peltigera polydactyla. New Phytologist 71, 31-39.

Hill DJ (1985) Changes in photobiont dimensions and numbers during co-development of lichen symbionts. In Brown DH (ed.), Lichen Physiology and Cell Biology. New York and London: Plenum Press, pp. 303-317.

Hill DJ (1989) The control of the cell cycle in microbial symbionts. New Phytologist 112, 175-184.

Hill DJ (2009) Asymmetrical co-evolution in the lichen symbiosis caused by a limited capacity for adaptation in the photobiont. Botanical Review $\mathbf{7 5}$, 326-338.

Hitch CBJ and Millbank JW (1975) Nitrogen metabolism in lichens VII. Nitrogenase activity and heterocyst frequency in lichens with blue-green phycobionts. New Phytologist 75, 239-244.

Hodač L, Hallmann C, Spitzer K, Elster J, Faßhauer F, Brinkmann N, Lepka D, Diwan V and Fried T (2016) Widespread green algae Chlorella and Stichococcus exhibit polar-temperate and tropical-temperate biogeography. FEMS Microbiology Ecology 92, fiw122.

Hodkinson BP, Moncada B and Lücking R (2014) Lepidostromatales, a new order of lichenized fungi (Basidiomycota, Agaricomycetes), with two new genera, Ertzia and Sulzbacheromyces, and one new species, Lepidostroma winklerianum. Fungal Diversity 64, 165-179.

Honegger R (1986) Ultrastructural studies in lichens I. Haustorial types and their frequencies in a range of lichens with trebouxioid photobionts. New Phytologist 103, 785-795.

Honegger R (1987) Questions about pattern formation in the algal layer of lichens with stratified (heteromerous) thalli. Bibliotheca Lichenologica 25, 59-71.

Honegger R (1990) Haustoria-like structures and cell wall surface layers in lichens. In Mendgen $\mathrm{K}$ and Leseman DE (eds), Electron Microscopy of Plant Pathogens. Berlin: Springer-Verlag, pp. 277-290.

Honegger R (1991) Functional aspects of the lichen symbiosis. Annual Review of Plant Physiology and Plant Molecular Biology 42, 553-578.

Honegger R (2012) The symbiotic phenotype of lichen-forming ascomycetes and their endo- and epibionts. In Hock B (ed.), The Mycota IX: Fungal Associations. Berlin and Heidelberg: Springer-Verlag, pp. 287-339.

Honegger R and Brunner U (1981) Sporopollenin in the cell wall of Coccomyxa and Myrmecia phycobionts of various lichens: an ultrastructural and chemical investigation. Canadian Journal of Botany 59, 2713-2734.

Hoshina R and Imamura N (2008) Multiple origins of the symbioses in Paramecium bursaria. Protist 159, 53-63.

Hoshina R, Kamako S-i and Imamura N (2004) Phylogenetic position of endosymbiotic green algae in Paramecium bursaria Ehrenberg from Japan. Plant Biology 6, 447-453.
Hoshina R, Iwataki M and Imamura N (2010) Chlorella variabilis and Micractinium reisseri sp. nov. (Chlorellaceae, Trebouxiophyceae): redescription of the endosymbiotic green algae of Paramecium bursaria (Peniculia, Oligohymenophorea) in the 120th year. Phycological Research 58, 188-201.

Huss VAR, Frank C, Hartmann EC, Hirmer M, Kloboucek A, Seidel B, Wenzeler P and Kessler E (1999) Biochemical taxonomy and molecular phylogeny of the genus Chlorella sensu lato (Chlorophyta). Journal of Phycology 35, 587-598.

Ihda T, Nakano T and Deguchi H (1997) Photobionts of Japanese Sphaerophorus. Symbiosis 23, 1-8.

Ikeda T and Takeda H (1995) Species-specific differences of pyrenoids in Chlorella (Chlorophyta). Journal of Phycology 31, 813-818.

Jaag O and Thomas E (1934) Neue Untersuchungen über die Flechte Epigloea bactrospora Zukal. Berichte der Schweizerschen Botanischen Gesellschaft 43, $77-89$.

Jacobs JB and Ahmadjian V (1971) The ultrastructure of lichens. IV. Movement of carbon products from alga to fungus as demonstrated by high resolution autoradiography. New Phytologist 70, 47-50.

Jahns HM, Mollenhauer D, Jenniger M and Schönborn D (1979) Die Neubesiedlung von Baumrinde durch Flechten I. Natur und Museum 109, 40-51.

Jaklitsch W, Baral H-O, Lücking R and Lumbsch HT (2016) Syllabus of Plant Families: A. Engler's Syllabus der Pflanzenfamilien. Part 1/2, Ascomycota. Stuttgart: Borntraeger Verlagsbuchhandlung.

James PW and Henssen A (1976) The morphological and taxonomic significance of cephalodia. In Brown DH, Hawksworth DL and Bailey RH (eds), Lichenology: Progress and Problems. London: Academic Press, pp. 27-77.

Jayalal U, Aptroot A and Hur J-S (2012) The lichen genus Polychidium new to South Korea. Mycobiology 40, 252-254.

Jiang SH, Hawksworth DL, Lücking R and Wei JC (2020) A new genus and species of foliicolous lichen in a new family of Strigulales (Ascomycota: Dothideomycetes) reveals remarkable class-level homoplasy. IMA Fungus 11, 1.

Joneson S and O'Brien H (2017) A molecular investigation of free-living and lichenized Nostoc sp. and symbiotic lifestyle determination. Bryologist 120, 371-381.

Jordan WP (1970) The internal cephalodia of the genus Lobaria. Bryologist 73, 669-681.

Jordan WP (1972) Erumpent cephalodia, an apparent case of phycobial influence on lichen morphology. Journal of Phycology 8, 112-117.

Jordan WP and Rickson F (1971) Cyanophyte cephalodia in the lichen genus Nephroma. American Journal of Botany 58, 562-568.

Joubert JJ and Rijkenberg FJH (1971) Parasitic green algae. Annual Review of Phytopathology 9, 45-64.

Jülich W (1972) Monographie der Atheliae (Corticiaceae, Basidiomycetes). Willdenowia, Beiheft 7, 1-283.

Jülich W (1978) A new lichenized Athelia from Florida. Persoonia 10, 149-151.

Jung P, Emrich D, Briegel-Williams L, Schermer M, Weber L, Baumann K, Colesie C, Clerc P, Lehnert LW, Achilles S, et al. (2019) Ecophysiology and phylogeny of new terricolous and epiphytic chlorolichens in a fog oasis of the Atacama Desert. MicrobiologyOpen 8, e894.

Jüriado I, Kaasalainen U, Jylhä and Rikkinen J (2019) Relationships between mycobiont identity, photobiont specificity and ecological preferences in the lichen genus Peltigera (Ascomycota) in Estonia (northeastern Europe). Fungal Ecology 39, 45-54.

Kardish N, Kessel M and Galun M (1989) Characterization of symbiotic and cultured Nostoc of the lichen Nephroma laevigatum Ach. Symbiosis 7, 257-266.

Keeling PJ (2004) Diversity and evolutionary history of plastids and their hosts. American Journal of Botany 91, 1481-1493.

Keeling PJ (2013) The number, speed, and impact of plastid endosymbioses in eukaryotic evolution. Annual Review of Plant Biology 64, 583-607.

Kharkongor D and Ramanujam P (2015) Spatial and temporal variation of carotenoids in four species of Trentepohlia (Trentepohliales, Chlorophyta). Journal of Botany 2015, 201641.

Khayatan B, Meeks J and Risser DD (2015) Evidence that a modified type IV pilus-like system powers gliding motility and polysaccharide secretion in filamentous cyanobacteria. Molecular Microbiology 98, 1021-1036. 
Kim JI, Nam SW, So JE, Hong SG, Choi HG and Shin W (2017) Asterochloris sejongensis sp. nov. (Trebouxiophyceae, Chlorophyta) from King George Island, Antarctica. Phytotaxa 295, 60-70.

Kim JI, Kim YJ, Nam SW, So JE, Hong SG, Choi H-G and Shin W (2020) Taxonomic study of three new Antarctic Asterochloris (Trebouxiophyceae) based on morphological and molecular data. Algae 35, 17-32.

Kirk PM, Cannon PF, David JC and Stalpers JA (2001) Ainsworth and Bisby's Dictionary of the Fungi, 9th Edn. Wallingford: CAB International.

Kluge M, Mollenhauer D, Wolf E and Schüßler A (2002) The Nostoc-Geosiphon endocytobiosis. In Rai AN, Bergman B and Rasmussen U (eds), Cyanobacteria in Symbiosis. Dordrecht: Kluwer Academic Publishers, pp. 19-30.

Kohlmeyer J, Hawksworth DL and Volkmann-Kohlmeyer B (2004) Observations on two marine and maritime 'borderline' lichens: Mastodia tessellata and Collemopsidium pelvetiae. Mycological Progress 3, 51-56.

Komárek J, Kaštovský J, Mareš J and Johansen JR (2014) Taxonomic classification of cyanoprokaryotes (cyanobacterial genera) 2014, using a polyphasic approach. Preslia 86, 295-335.

Kono M, Kon Y, Ohmura Y, Satta Y and Terai Y (2020) In vitro resynthesis of lichenization reveals the genetic background of symbiosis-specific fungal-algal interaction in Usnea hakonensis. BMC Genomics 21, 1-16.

Kosecka M, Jabłońska A, Flakus A, Rodriguez-Flakus P, Kukwa $M$ and Guzow-Krzemińska B (2020) Trentepohlialean algae (Trentepohliales, Ulvophyceae) show preference to selected mycobiont lineages in lichen symbioses. Journal of Phycology 56, 979-993.

Kosecka M, Guzow-Krzemińska B, Čemajová I, Škaloud P, Jabłońska A and Kukwa M (2021) New lineages of photobionts in Bolivian lichens expand our knowledge on habitat preferences and distribution of Asterochloris algae. Scientific Reports 11, 8701.

Kosugi M, Arita M, Shizuma R, Moryama Y, Kashino Y, Koike H and Satoh K (2009) Responses to desiccation stress in lichens are different from those in their photobionts. Plant and Cell Physiology 50, 879-888.

Kouwets FAC (1996) Ultrastructural studies of the cell cycle in a multicentriolar form of Bracteacoccus minor (Chlorophyceae, Chlorellales). Protoplasma 191, 191-204.

Kovačević G, Franjević D, Jelenčić B and Kalafatić M (2010) Isolation and cultivation of endosymbiotic algae from green hydra and phylogenetic analysis of 18S rDNA sequences. Folia Biologica (Kraków) 58, 135-143.

Kovačik L and Batista Pereira A (2001) Green alga Prasiola crispa and its lichenized form Mastodia tesselata in Antarctic environment: general aspects. Nova Hedwigia 123, 465-478.

Kranner I, Cram WJ, Zorn M, Wornik S, Yoshimura I, Stabentheiner E and Pfeifhofer HW (2005) Antioxidants and photoprotection in a lichen as compared with its isolated symbiotic partners. Proceedings of the National Academy of Sciences of the United States of America 102, 3141-3146.

Kranner I, Beckett R, Hochman A and Nash, TH III (2008) Desiccation-tolerance in lichens: a review. Bryologist 111, 576-593.

Kroken S and Taylor JW (2000) Phylogenetic species, reproductive mode, and specificity of the green alga Trebouxia forming lichens with the fungal genus Letharia. Bryologist 103, 645-660.

Kukwa M and Pérez-Ortega S (2010) A second species of Botryolepraria from the Neotropics and the phylogenetic placement of the genus within Ascomycota. Mycological Progress 9, 345-351.

Kumar K, Mella-Herrera RA and Golden JW (2010) Cyanobacterial heterocysts. Cold Spring Harbor Perspectives in Biology 2, a000315.

Lakatos M, Lange-Bertalot H and Büdel B (2004) Diatoms living inside the thallus of the green algal lichen Coenogonium linkii in neotropical lowland rain forests. Journal of Phycology 40, 70-73.

Lamb IM (1959) Lichens. Scientific American 201, 144-159.

Lange OL, Kilian E and Ziegler H (1986) Water vapor uptake and photosynthesis of lichens: performance differences in species with green and bluegreen algae as phycobionts. Oecologia 71, 104-110.

Lange OL, Pfanz H, Kilian E and Meyer A (1990) Effect of low water potential on photosynthesis in intact lichens and their liberated algal components. Planta 182, 467-472.

Lange OL, Büdel B, Meyer A and Kilian E (1993) Further evidence that activation of net photosynthesis by dry cyanobacterial lichens requires liquid water. Lichenologist 25, 175-189.
Lavoie C, Renaudin M, McMullin RT, Ganon J, Roy C, Beaulieu M-E, Bellenger JP and Villareal JC (2020) Extremely low genetic diversity of Stigonema associated with Stereocaulon in eastern Canada. Bryologist 123, 188-203.

Leavitt SD, Nelsen MP, Lumbsch HT, Johnson LA and St Clair LL (2013) Symbiont flexibility in subalpine rock shield lichen communities in the Southwestern USA. Bryologist 116, 149-161.

Leavitt SD, Kraichak E, Vondrak J, Nelsen MP, Altermann S, Divakar PK, Alors D, Esslinger TL, Crespo A and Lumbsch HT (2015) Fungal specificity and selectivity for algae play a major role in determining lichen partnerships across diverse ecogeographic regions in the lichen-forming family Parmeliaceae (Ascomycota). Molecular Ecology 24, 3779-3797.

Leavitt SD, Kraichak E, Vondrak J, Nelsen MP, Sohrabi M, Pérez-Ortega S, St Clair LL and Lumbsch HT (2016) Cryptic diversity and symbiont interactions in rock-posy lichens. Molecular Phylogenetics and Evolution 99, 261-274.

Lee RE (2018) Phycology, 5th Edn. Cambridge: Cambridge University Press. Leliaert F, Smith DR, Moreau H, Herron MD, Verbruggen H, Delwiche CF and De Clerck O (2012) Phylogeny and molecular evolution of the green algae. Critical Reviews in Plant Sciences 31, 1-46.

Lemieux C, Otis C and Turmel M (2014) Chloroplast phylogenomic analysis resolves deep-level relationships within the green algal class Trebouxiophyceae. BMC Evolutionary Biology 14, 211.

Letrouit-Galinou M-A (1968) Les algues des lichens. Bulletin de la Société Botanique de France 115 (Supp. 2), 35-77.

Letrouit-Galinou M-A and Asta J (1994) Thallus morphogenesis in some lichens. Cryptogamic Botany 4, 274-282.

Letsch MR, Muller-Parker G, Friedl T and Lewis LA (2009) Elliptochloris marina sp. nov. (Trebouxiophyceae, Chlorophyta), symbiotic green alga of the temperate pacific sea anemones Anthopleura xanthogrammica and A. elegantissima (Anthozoa, Cnidaria). Journal of Phycology 45, $1127-1135$.

Lewis L and Muller-Parker G (2004) Phylogenetic placement of 'Zoochlorella' (Chlorophyta), algal symbiont of the temperate sea anemone Anthopleura elegantissima. Biological Bulletin 207, 87-92.

Li B, Feng J and Xie S (2013) Morphological and phylogenetic study of algal partners associated with the lichen-forming fungus Porpidia crustulata from the Guancen Mountains, northern China. Symbiosis 61, 37-46.

Li S, Sun H, Hu Y, Liu B, Zhu H, Hu Z and Liu G (2020) Four new members of foliicolous green algae within the Watanabea clade (Trebouxiophyceae, Chlorophyta) from China. Journal of Eukaryotic Microbiology 67, 369-382.

Li S, Tan H, Liu B, Zhu H, Hu Z and Liu G (2021) Watanabeales ord. nov. and twelve novel species of Trebouxiophyceae (Chlorophyta). Journal of Phycology, doi: 10.1111/JPY.13165

Lindgren H, Velmala S, Högnabba F, Goward T, Holien H and Myllys L (2014) High fungal selectivity for algal symbionts in the genus Bryoria. Lichenologist 46, 681-695.

Lindgren H, Moncada B, Lücking R, Magain N, Simon A, Goffinet B, Sérusiaux E, Nelsen M, Mercado-Díaz J, Widhelm T, et al. (2020) Cophylogenetic patterns in algal symbionts correlate with repeated symbiont switches during diversification and geographic expansion of lichenforming fungi in the genus Sticta (Ascomycota: Peltigeraceae). Molecular Phylogenetics and Evolution 150, 106860.

Liu A, Zhu T, Lu X and Song L (2013) Hydrocarbon profiles and phylogenetic analyses of diversified cyanobacterial species. Applied Energy 111, 383-393.

Lohtander K, Oksanen I and Rikkinen J (2003) Genetic diversity of green algal and cyanobacterial photobionts in Nephroma (Peltigerales). Lichenologist 35, 325-339.

López-Bautista JM and Chapman RL (2003) Phylogenetic affinities of the Trentepohliales inferred from small-subunit rDNA. International Journal of Systematic and Evolutionary Microbiology 53, 2099-2106.

López-Bautista JM, Rindi F and Guiry MD (2006) Molecular systematics of the subaerial green algal order Trentepohliales: an assessment based on morphological and molecular data. International Journal of Systematic and Evolutionary Microbiology 56, 1709-1715.

Lücking R (1994) A new foliicolous species of Microtheliopsis (Lichens, Microtheliopsidaceae) from Costa Rica. Mycotaxon 51, 69-73.

Lücking R (2008) Foliicolous lichenized fungi. Flora Neotropica Monograph 103, 1-866. 
Lücking R and Grube $\mathbf{M}$ (2002) Facultative parasitism and reproductive strategies in Chroodiscus (Ascomycota, Ostropales). Stapfia 80, 267-292.

Lücking R, Lawrey JD, Sikaroodi M, Gilleve PM, Chaves JL, Sipman HJM and Bungartz F (2009) Do lichens domesticate photobionts like farmers domesticate crops? Evidence from a previously unrecognized lineage of filamentous cyanobacteria. American Journal of Botany 96, 1409-1418.

Lücking R, Barrie FR and Genney D (2014) Dictyonema coppinsii, a new name for the European species known as Dictyonema interruptum (Basidiomycota: Agaricales: Hygrophoraceae), with a validation of its photobiont Rhizonema (Cyanoprokaryota: Nostocales: Rhizonemataceae). Lichenologist 46, 261-267.

Lücking R, Hodkinson BP and Leavitt SD (2017a) The 2016 classification of lichenized fungi in the Ascomycota and Basidiomycota - approaching one thousand genera. Bryologist 119, 361-416.

Lücking R, Thorn RG, Saar I, Piercey-Normore MD, Moncada B, Doering J, Mann H, Lebeuf R, Voitk M and Voitk A (2017b) A hidden basidiolichen rediscovered: Omphalina oreades is a separate species in the genus Lichenomphalia (Basidiomycota: Agaricales: Hygrophoraceae). Lichenologist 49, 467-481.

Lud D, Huiskes AHL and Ott S (2001) Morphological evidence for the symbiotic character of Turgidosculum complicatulum Kohlm. \& Kohlm. (= Mastodia tesselata Hook. f. \& Harvey). Symbiosis 31, 141-151.

Ludwig LR (2015) The reproductive ecology of Icmadophila splachnirima, including aspects of the reproduction in additional members of Icmadophilaceae. Ph.D. thesis, University of Otago.

Luo W, Pröschold T, Bock C and Krienitz L (2010) Generic concept in Chlorella-related coccoid green algae (Chlorophyta, Trebouxiophyceae). Plant Biology 12, 545-553.

Lutsak T, Fernández-Mendoza F, Kirika $P$, Wondafrash $M$ and Printzen $C$ (2016) Mycobiont-photobiont interactions of the lichen Cetraria aculeata in high alpine regions of East Africa and South America. Symbiosis 68, 25-37.

Lutzoni FM and Brodo IM (1995) A generic redelimitation of the IonaspisHymenelia complex (lichenized Ascomycotina). Systematic Botany 20, 224-258.

Ma S, Huss VAR, Tan D, Sun X, Chun J, Xie Y and Zhang J (2013) A novel species in the genus Heveochlorella (Trebouxiophyceae, Chlorophyta) witnesses the evolution from an epiphytic into an endophytic lifestyle in tree-dwelling green algae. European Journal of Phycology 48, 200-209.

Magain N and Sérusiaux E (2014) Do photobiont switch and cephalodia emancipation act as evolutionary drivers in the lichen symbiosis? A case study in the Pannariaceae (Peltigerales). PLoS ONE 9, e89876.

Magain N, Goffinet B and Sérusiaux E (2012) Further photomorphs in the lichen family Lobariaceae from Réunion (Mascarene archipelago) with notes on the phylogeny of Dendriscocaulon cyanomorphs. Bryologist 115, 243-254.

Magain N, Miadlikowska J, Goffinet B, Sérusiaux E and Lutzoni F (2017) Macroevolution of specificity in cyanolichens of the genus Peltigera section Polydactylon (Lecanoromycetes, Ascomycota). Systematic Botany 66, 74-99.

Magain N, Truong C, Goward T, Niu D, Goffinet B, Sérusiaux E, Vitikainen O, Lutzoni F and Miadlikowska J (2018) Species delimitation at a global scale reveals high species richness with complex biogeography and patterns of symbiont association in Peltigera section Peltigera (lichenized Ascomycota: Lecanoromycetes). Taxon 67, 836-870.

Makra N, Gell G, Juhász A, Soós V, Kiss T, Molnár Z, Ördög V, Vörös L and Balázs E (2019) Molecular taxonomic evaluation of Anabaena and Nostoc strains from the Mosonmagyaróvár Algal Culture Collection. South African Journal of Botany 124, 80-86.

Malavasi V, Škaloud P, Rindi F, Tempesta S, Paoletti M and Pasqualetti M (2016) DNA-based taxonomy in ecologically versatile microalgae: a re-evaluation of the species concept within the coccoid green algal genus Coccomyxa (Trebouxiophyceae, Chlorophyta). PLoS ONE 11, e0151137.

Mansournia MR, Wu B, Matsushita N and Hogetsu T (2012) Genotypic analysis of the foliose lichen Parmotrema tinctorum using microsatellite markers: association of mycobiont and photobiont, and their reproductive modes. Lichenologist 44, 419-440.

Marini L, Nascimbene J and Nimis PL (2011) Large-scale patterns of epiphytic lichen species richness: photobiont-dependent response to climate and forest structure. Science of the Total Environment 409, 4381-4386.

Mark K, Laanisto L, Bueno CG, Niinemets Ü, Keller C and Scheidegger C (2020) Contrasting co-occurrence patterns of photobiont and cystobasidiomycete yeast associated with common epiphytic lichen species. New Phytologist 227, 1362-1375.

Marton K and Galun M (1976) In vitro dissociation and reassociation of the symbionts of the lichen Heppia echinulata. Protoplasma 87, $135-143$.

Masumoto H (2020) Taxonomic studies on lichenized basidiomycetes and their photobionts in Japan: towards the establishment of a model co-culture system of lichen symbiosis. Ph.D. thesis, University of Tsukuba.

Masumoto H, Ohmura Y and Degawa Y (2019) Lichenomphalia meridionalis (Hygrophoraceae, lichenized Basidiomycota) new to Asia. Opuscula Philolichenum 18, 379-389.

Matthews SW, Tucker SC and Chapman RL (1989) Ultrastructural features of mycobionts and trentepohliaceous phycobionts in selected tropical crustose lichens. Botanical Gazette 150, 417-438.

Mattox KR and Stewart KD (1984) Classification of the green algae: a concept based on comparative cytology. In Irvine DEG and John DM (eds), Systematics of the Green Algae. London: Academic Press, pp. 29-72.

McCune B, Arup U, Breuss O, Di Meglio E, Di Meglio J, Esslinger TL, Magain N, Miadlikowska J, Miller AE, Muggia L, et al. (2018) Biodiversity and ecology of lichens of Katmai and Lake Clark National Parks and Preserves, Alaska. Mycosphere 9, 859-930.

McGee M (2002) Back cover. Bulletin of the California Lichen Society 9, 25-26. Meeks JC (1998) Symbiosis between nitrogen-fixing cyanobacteria and plants. BioScience 48, 266-276.

Meier FA, Scherrer S and Honegger R (2002) Faecal pellets of lichenivorous mites contain viable cells of the lichen-forming ascomycete Xanthoria parietina and its green algal photobiont, Trebouxia arboricola. Biological Journal of the Linnean Society 76, 259-268.

Meier JL and Chapman RL (1983) Ultrastructure of the lichen Coenogonium interplexum Nyl. American Journal of Botany 70, 400-407.

Metz S, Singer D, Domaizon I, Unrein F and Lara E (2019) Global distribution of Trebouxiophyceae diversity explored by high-throughput sequencing and phylogenetic approaches. Environmental Microbiology 21, 3885-3895.

Miadlikowska J, Kauff F, Högnabba F, Oliver JC, Molnár K, Fraker E, Gaya E, Hafellner J, Hofstetter V, Gueidan C, et al. (2014) A multigene phylogenetic synthesis for the class Lecanoromycetes (Ascomycota): 1307 fungi representing 1139 infrageneric taxa, 317 genera and 66 families. Molecular Phylogenetics and Evolution 79, 132-168.

Míguez F, Schiefelbein U, Karsten U, García-Plazaola JI and Gustavs L (2017) Unraveling the photoprotective response of lichenized and freeliving green algae (Trebouxiophyceae, Chlorophyta) to photochilling stress. Frontiers in Plant Science 8, 1144.

Mikhailyuk TI, Sluiman HJ, Massalski A, Mudimu O, Demchenko EM, Kondratyuk SY and Friedl T (2008) New streptophyte green algae from terrestrial habitats and an assessment of the genus Interfilum (Klebsormidiophyceae, Streptophyta). Journal of Phycology 44, 1586-1603.

Mikhailyuk T, Holzinger A, Tsarenko P, Glaser K, Demchenko E and Karsten U (2020) Dictyosphaerium-like morphotype in terrestrial algae: what is Xerochlorella (Trebouxiophyceae, Chlorophyta)? Journal of Phycology 56, 671-686.

Millbank JW and Kershaw KA (1974 ['1973']) Nitrogen metabolism. In Ahmadjian V and Hale ME (eds), The Lichens. New York: Academic Press, pp. 289-307.

Moe RL (1997) Verrucaria tavaresiae sp. nov., a marine lichen with a brown algal photobiont. Bulletin of the California Lichen Society 4, 7-11.

Mohr F, Ekman S and Heegaard E (2004) Evolution and taxonomy of the marine Collemopsidium species (lichenized Ascomycota) in north-west Europe. Mycological Research 108, 515-532.

Molinari-Novoa EA (2016) Uvulifera, a new generic name for Coccobotrys (Chaetophoraceae). Notulae Algarum 5, 1-2.

Molins A, García-Breijo F, Reig-Armiñana J, del Campo E, Casano L and Barreno E (2013) Coexistence of different intrathalline symbiotic algae and bacterial biofilms in the foliose Canarian lichen Parmotrema pseudotinctorum. Vieraea 41, 249-270.

Molins A, Moya P, García-Breijo F, Reig-Armiñana J and Barreno E (2018) Molecular and morphological diversity of Trebouxia microalgae in sphaerothallioid Circinaria spp. lichens. Journal of Phycology 54, 494-504. 
Molins A, Chiva S, Calatayud A, Marco F, García-Breijo F, Reig-Armiñana J, Carrasco P and Moya P (2020) Multidisciplinary approach to describe Trebouxia diversity within lichenized fungi Buellia zoharyi from the Canary Islands. Symbiosis 82, 19-34.

Moncada B, Coca LF and Lücking R (2013) Neotropical members of Sticta (lichenized Ascomycota: Lobariaceae) forming photosymbiodemes, with the description of seven new species. Bryologist 116, 169-200.

Moniz MBJ, Rindi F and Guiry MD (2012) Phylogeny and taxonomy of Prasiolales (Trebouxiophyceae, Chlorophyta) from Tasmania, including Rosenvingiella tasmanica sp. nov. Phycologia 51, 86-97.

Moniz MBJ, Guiry MD and Rindi F (2014) TufA phylogeny and species boundaries in the green algal order Prasiolales (Trebouxiophyceae, Chlorophyta). Phycologia 53, 396-406.

Moya P, Škaloud P, Chiva S, García-Breijo FJ, Reig-Armiñana J, Vančurová L and Barreno E (2015) Molecular phylogeny and ultrastructure of the lichen microalga Asterochloris mediterranea sp. nov. from Mediterranean and Canary Islands ecosystems. International Journal of Systematic and Evolutionary Microbiology 65, 1838-1854.

Moya P, Molins A, Martínez-Alberola F, Muggia L and Barreno E (2017) Unexpected associated microalgal diversity in the lichen Ramalina farinacea is uncovered by pyrosequencing analyses. PLOS ONE 12, e0175091.

Moya P, Chiva S, Molins A, Jadrná I, Škaloud P, Peksa $O$ and Barreno E (2018) Myrmecia israelensis as the primary symbiotic microalga in squamulose lichens growing in European and Canary Island terricolous communities. Fottea 18, 72-85.

Muggia L and Grube M (2018) Fungal diversity in lichens: from extremotolerance to interactions with algae. Life 8, 15.

Muggia L, Grube $\mathbf{M}$ and Tretiach $\mathbf{M}$ (2008) Genetic diversity and photobiont association in selected taxa of the Tephromela atra group (Lecanorales, lichenized Ascomycota). Mycological Progress 7, 147-160.

Muggia L, Zellnig G, Rabensteiner J and Grube M (2010) Morphological and phylogenetic study of algal partners associated with the lichen-forming fungus Tephromela atra from the Mediterranean region. Symbiosis 51, 149-160.

Muggia L, Baloch E, Stabentheiner E, Grube M and Wedin M (2011) Photobiont association and genetic diversity of the optionally lichenized fungus Schizoxylon albescens. FEMS Microbiology Ecology 75, 255-272.

Muggia L, Vancurova L, Škaloud P, Peksa O, Wedin M and Grube M (2013) The symbiotic playground of lichen thalli - a highly flexible photobiont association in rock-inhabiting lichens. FEMS Microbiology Ecology 85, 313-323.

Muggia L, Pérez-Ortega S, Kopun T, Zellnig G and Grube M (2014) Photobiont selectivity leads to ecological tolerance and evolutionary divergence in a polymorphic complex of lichenized fungi. Annals of Botany 114, 463-475.

Muggia L, Candotto-Carniel F and Grube M (2017) The lichen photobiont Trebouxia: towards and appreciation of species diversity and molecular studies. In Grube M, Seckbach J and Muggia L (eds), Algal and Cyanobacterial Symbioses. London: World Scientific Publishing Europe Ltd, pp. 111-146.

Muggia L, Leavitt S and Barreno E (2018) The hidden diversity of lichenised Trebouxiophyceae (Chlorophyta). Phycologia 57, 503-524.

Muggia L, Nelsen MP, Kirika PM, Barreno E, Beck A, Lindgren H, Lumbsch HT, Leavitt SD and Trebouxia working group (2020) Formally described species woefully underrepresent phylogenetic diversity in the common lichen photobiont genus Trebouxia (Trebouxiophyceae, Chlorophyta): an impetus for developing an integrated taxonomy. Molecular Phylogenetics and Evolution 149, 106821.

Mukherjee R, Borah SP and Goswami BC (2010) Biochemical characterization of carotenoids in two species of Trentepohlia (Trentepohliales, Chlorophyta). Journal of Applied Phycology 22, 569-571.

Mukhtar A, Garty J and Galun M (1994) Does the lichen alga Trebouxia occur free-living in nature: further immunological evidence. Symbiosis 17, 247-253.

Myllys L, Stenroos S, Thell A and Kuusinen M (2007) High cyanobiont selectivity of epiphytic lichens in old growth boreal forest of Finland. New Phytologist 173, 621-629.

Nakano T (1988) Phycobionts of some Japanese species of the Graphidaceae. Lichenologist 20, 353-360.

Nakano T and Iguchi K (1994) Photobionts isolated from some Japanese species of Cladonia (lichens). Symbiosis 17, 65-73.
Nakano T and Ihda T (1996) The identity of photobionts from the lichen Pyrenula japonica. Lichenologist 28, 437-442.

Namba $\mathbf{N}$ and Nakayama T (2021) Taxonomic study of a new green alga, Annulotesta cochlephila gen. et sp. nov. (Kornmanniaceae, Ulvales, Ulvophyceae), growing on the shells of door snails. Journal of Plant Research 134, 77-89.

Nash, TH III, Kappen L, Lösch R, Larson DW and Matthes-Sears U (1987) Cold resistance of lichens with Trentepohlia- or Trebouxia-photobionts from the North American west coast. Flora 170, 241-251.

Nelsen MP and Gargas A (2008) Dissociation and horizontal transmission of codispersing lichen symbionts in the genus Lepraria (Lecanorales: Stereocaulaceae). New Phytologist 177, 264-275.

Nelsen MP and Gargas A (2009) Symbiont flexibility in Thamnolia vermicularis (Pertusariales: Icmadophilaceae). Bryologist 104, 404-417.

Nelsen MP, Rivas Plata E, Andrew CJ, Lücking R and Lumbsch HT (2011) Phylogenetic diversity of trentepohlialean algae associated with lichenforming fungi. Journal of Phycology 47, 282-290.

Nelson DR, Khraiwesh B, Fu W, Alseekh S, Jaiswal A, Chaiboonchoe A, Hazzouri KM, O'Connor MJ, Butterfoss GL, Dro N, et al. (2017) The genome and phenome of the green alga Chloroidium sp. UTEX 3007 reveal adaptive traits for desert acclimatization. eLife 6, e25783.

Němcová Y and Kalina T (2000) Cell wall development, microfibril and pyrenoid structure in type strains of Chlorella vulgaris, C. kessleri, C sorokiniana compared with C. luteoviridis (Trebouxiophyceae, Chlorophyta). Algological Studies 100, 95-105.

Neustupa J (2015) Division Chlorophyta. In Frey W (series ed.), Syllabus of Plant Families: 2/1 Photoautotrophic Eukaryotic Algae. Stuttgart: Borntraeger Verlagsbuchhandlung, pp. 191-247.

Neustupa J and Štifterová S (2013) Distribution patterns of subaerial corticolous microalgae in two European regions. Plant Ecology and Evolution 146, 279-289.

Neustupa J, Němcová Y, Eliáš M and Škaloud P (2009) Kalinella bambusicola gen. et sp. nov. (Trebouxiophyceae, Chlorophyta), a novel coccoid Chlorella-like subaerial alga from Southeast Asia. Phycological Research 57, 159-169.

Nyati S, Beck A and Honegger R (2007) Fine structure and phylogeny of green algal photobionts in the microfilamentous genus Psoroglaena (Verrucariaceae, lichen-forming ascomycetes). Plant Biology 9, 390-399.

Nyati S, Bhattacharya D, Werth S and Honegger R (2013) Phylogenetic analysis of LSU and SSU rDNA group I introns of lichen photobionts associated with the genera Xanthoria and Xanthomendoza (Teloschistaceae, lichenized Ascomycetes). Journal of Phycology 49, 1154-1166.

Nyati S, Scherrer S, Werth S and Honegger R (2014) Green-algal photobiont diversity (Trebouxia spp.) in representatives of Teloschistaceae (Lecanoromycetes, lichen-forming ascomycetes). Lichenologist 46, 189-212.

O'Brien H, Miadlikowsa J and Lutzoni F (2005) Assessing host specialization in symbiotic cyanobacteria associated with four closely related species of the lichen fungus Peltigera. European Journal of Phycology 40, 363-378.

O'Brien H, Miadlikowsa J and Lutzoni F (2013) Assessing population structure and host specialization in lichenized cyanobacteria. New Phytologist 198, 557-566.

Oberwinkler F (1980) Symbiotic relationship between fungus and alga in basidiolichens. In Schwemmler W and Schenk HEA (eds), Endocytobiology: Endosymbiosis and Cell Biology, Vol. I. Berlin: Walter de Gruyter, pp. 305-315.

Oberwinkler F (1984) Fungus-alga interactions in basidiolichens. In Hertel H and Oberwinkler F (eds), Festschrift Josef Poelt: Beiheft Beiträge zur Lichenologie. Vaduz: J. Cramer, pp. 739-774.

Oberwinkler F (2012) Basidiolichens. In Hock B (ed.), The Mycota IX. Fungal Associations, 2nd Edn. Berlin: Springer-Verlag, pp. 341-362.

Ohmura Y, Kawachi M, Kasai F, Watanabe MM and Takeshita S (2006) Genetic combinations of symbionts in a vegetatively reproducing lichen, Parmotrema tinctorum, based on ITS rDNA sequences. Bryologist 109, 43-59.

Ohmura Y, Takeshita S and Kawachi M (2019) Photobiont diversity within populations of a vegetatively reproducing lichen, Parmotrema tinctorum, can be generated by photobiont switching. Symbiosis 77, 59-72.

Oksanen I, Lohtander K, Paulsrud P and Rikkinen J (2002) A molecular approach to cyanobacterial diversity in a rock-pool community involving 
gelatinous lichens and free-living Nostoc colonies. Annales Botanici Fennici 39, 93-99.

Onuț-Brännström I, Tibell L and Johannesson H (2017) A worldwide phylogeography of the whiteworm lichens Thamnolia reveals three lineages with distinct habitats and evolutionary histories. Ecology and Evolution 7, 3602-3615.

Onuț-Brännström I, Benjamin M, Scofield DG, Heiđmarsson S, Andersson MGI, Lindström ES and Johannesson H (2018) Sharing of photobionts in sympatric populations of Thamnolia and Cetraria lichens: evidence from high-throughput sequencing. Scientific Reports 8, 4406.

Ortiz-Álvarez R, de los Ríos A, Fernández-Mendoza F, Torralba-Burrial A and Pérez-Ortega S (2015) Ecological specialization of two photobiontspecific maritime cyanolichen species of the genus Lichina. PLoS ONE 10, e0132718.

Osyczka P, Lenart-Borón A, Borón P and Rola K (2021) Lichen-forming fungi in postindustrial habitats involve alternative photobionts. Mycologia 113, 43-55.

Otálora MAG, Martínez I, O’Brien H, Molina MC, Aragón G and Lutzoni F (2010) Multiple origins of high reciprocal symbiotic specificity at an intercontinental spatial scale among gelatinous lichens (Collemataceae, Lecanoromycetes). Molecular Phylogenetics and Evolution 56, 1089-1095.

Otálora MAG, Salvador C, Martínez I and Aragón G (2013) Does the reproductive strategy affect the transmission and genetic diversity of bionts in cyanolichens? A case study using two closely related species. Microbial Ecology 65, 517-530.

Ott S (1988) Photosymbiodemes and their development in Peltigera venosa. Lichenologist 20, 361-368.

Palmqvist K, de los Ríos A, Ascaso C and Samuelsson G (1997) Photosynthetic carbon acquisition in the lichen photobionts Coccomyxa and Trebouxia (Chlorophyta). Physiologia Plantarum 101, 67-76.

Paran N, Ben-Shaul Y and Galun M (1971) Fine structure of the blue-green phycobiont and its relation to the mycobiont in two Gonohymenia lichens. Archiv für Mikrobiologie 76, 103-113.

Park CH, Kim KM, Elvebakk A, Kim O-S, Jeong G and Hong SG (2015) Algal and fungal diversity in Antarctic lichens. Journal of Eukaryotic Microbiology 62, 196-205.

Parra OO and Redón J (1977) Aislamiento de Heterococcus caespitosus Vischer ficobionte de Verrucaria maura. Boletin de la Sociedad de Biología de Concepción 51, 219-224.

Paul F, Otte J, Schmitt I and Dal Grande F (2018) Comparing Sanger sequencing and high-throughput metabarcoding for inferring photobiont diversity in lichens. Scientific Reports 8, 8624.

Paulsrud P (2001) The Nostoc symbiosis of lichens: diversity, specificity and cellular modifications. Acta Universitatis Upsaliensis: Comprehensive Summaries of Uppsala Dissertations from the Faculty of Science and Technology 662, 1-55.

Paulsrud P and Lindblad P (1998) Sequence variation of the tRNA ${ }^{\text {Leu }}$ intron as a marker for genetic diversity and specificity of symbiotic cyanobacteria in some lichens. Applied and Environmental Microbiology 64, 310-315.

Paulsrud P, Rikkinen J and Lindblad P (1998) Cyanobiont specificity in some Nostoc-containing lichens and in a Peltigera aphthosa photosymbiodeme. New Phytologist 139, 517-524.

Paulsrud P, Rikkinen J and Lindblad P (2000) Spatial patterns of photobiont diversity in some Nostoc-containing lichens. New Phytologist 146, 291-299.

Paulsrud P, Rikkinen J and Lindblad P (2001) Field investigations on cyanobacterial specificity in Peltigera aphthosa. New Phytologist 152, 117-123.

Peksa O and Škaloud P (2011) Do photobionts influence the ecology of lichens? A case study of environmental preferences in symbiotic green alga Asterochloris (Trebouxiophyceae). Molecular Ecology 20, 3936-3948.

Pereira Riquelme I (1992) Flora, vegetación y ecología de los líquenes acuáticos de España. Ph.D. thesis, University of Barcelona.

Pérez-Ortega S, de los Ríos A, Crespo A and Sancho LG (2010) Symbiotic lifestyle and phylogenetic relationships of the bionts of Mastodia tessellata (Ascomycota, incertae sedis). American Journal of Botany 97, 738-752.

Pérez-Ortega S, Ortiz-Álvarez R, Green TGA and de los Ríos A (2012) Lichen myco- and photobiont diversity and their relationships at the edge of life (McMurdo Dry Valleys, Antarctica). FEMS Microbiology Ecology 82, 429-448.
Pérez-Ortega S, Miller KA and de los Ríos A (2018) Challenging the lichen concept: Turgidusculum ulvae (Verrucariaceae) represents an independent photobiont shift to a multicellular blade-like alga. Lichenologist 50, 341-356.

Peršoh D, Beck A and Rambold G (2004) The distribution of ascus types and photobiontal selection in Lecanoromycetes (Ascomycota) against the background of a revised SSU nrDNA phylogeny. Mycological Progress 3, 103-121.

Peters AF and Moe RL (2001) DNA sequences confirm that Petroderma maculiforme (Phaeophyceae) is the brown algal phycobiont of the marine lichen Verrucaria tavaresiae (Verrucariales, Ascomycota) from central California. Bulletin of the California Lichen Society 8, 41-43.

Peveling E (1968) Pyrenoidstrukturen in symbiotisch lebenden Trebouxia-Arten. Zeitschrift für Pflanzenphysiologie 59, 393-396.

Peveling E (1969) Electronenoptische Untersuchungen an Flechten. II. Die Feinstruktur von Trebouxia-Phycobionten. Planta 87, 69-85.

Peveling E and Galun M (1976) Electron-microscopical studies on the phycobiont Coccomyxa Schmidle. New Phytologist 77, 713-718.

Piercey-Normore MD (2004) Selection of algal genotypes by three species of lichen fungi in the genus Cladonia. Canadian Journal of Botany 82, 947-961.

Piercey-Normore MD (2006) The lichen-forming ascomycete Evernia mesomorpha associates with multiple genotypes of Trebouxia jamesii. New Phytologist 169, 331-344.

Piercey-Normore MD (2009) Vegetatively reproducing fungi in three genera of the Parmeliaceae share divergent algal partners. Bryologist 112, 773-785.

Piercey-Normore MD and DePriest PT (2001) Algal switching among lichen symbioses. American Journal of Botany 88, 1490-1498.

Pino-Bodas R and Stenroos A (2020) Global biodiversity patterns of the photobionts associated with the genus Cladonia (Lecanorales, Ascomycota). Microbial Ecology, doi:10.1007/s00248-020-01633-3

Plessl A (1963) Über die Beziehung von Haustorientypus und Organisationshöhe bei Flechten. Österreichische Botanische Zeitschrift 110, 194-269.

Poelt J (1958) Über parasitische Flechten. II. Planta 51, 288-307.

Poelt J and Baumgärtner H (1964) Über Rhizinenstränge bei placodialen Flechten. Österreichische Botanische Zeitschrift 111, 1-18.

Prieto M, Schultz M, Olariaga I and Wedin M (2019) Lichinodium is a new lichenized lineage in the Leotiomycetes. Fungal Diversity 94, 23-39.

Pröschold T and Darienko T (2020) The green puzzle Stichococcus (Trebouxiophyceae, Chlorophyta): new generic and species concept among this widely distributed genus. Phytotaxa 441, 113-142.

Pröschold T, Darienko T, Silva P, Reisser W and Krienitz L (2011) The systematics of Zoochlorella revisited employing a molecular approach. Environmental Microbiology 13, 350-364.

Purvis OW, Coppins BJ, Hawksworth DL, James PW and Moore DM (1992) The Lichen Flora of Great Britain and Ireland. London: British Lichen Society.

Raggio J, Green TGA, Crittenden PD, Pintado A, Vivas M, Pérez-Ortega S, de los Ríos A and Sancho LG (2012) Comparative ecology of three Placopsis species, pioneer lichens in recently exposed Chilean glacial forelands. Symbiosis 56, 55-66.

Rajaniemi P, Hrouzek P, Kaštovská K, Willame R, Rantala A, Hoffmann L, Komárek J and Sivonen K (2005) Phylogenetic and morphological evaluation of the genera Anabaena, Aphanizomenon, Trichormus and Nostoc (Nostocales, Cyanobacteria). International Journal of Systematic and Evolutionary Microbiology 55, 11-26.

Rambold G, Friedl T and Beck A (1998) Photobionts in lichens: possible indicators of phylogenetic relationships? Bryologist 101, 392-397.

Ran L, Larsson J, Vigil-Stenman T, Nylander JAA, Ininbergs $K$, Zheng W-W, Lapidus A, Lowry S, Haselkorn R and Bergman B (2010) Genome erosion in a nitrogen-fixing vertically transmitted endosymbiotic multicellular cyanobacterium. PLoS ONE 5, e11486.

Richardson DHS, Hill DJ and Smith DC (1968) Lichen physiology. XI. The role of the alga in determining the pattern of carbohydrate movement between lichen symbionts. New Phytologist 67, 469-486.

Řidká T, Peksa O, Rai H, Upreti DK and Škaloud P (2014) Photobiont diversity in Indian Cladonia lichens, with special emphasis on the geographical patterns. In Rai $\mathrm{H}$ and Upreti DK (eds), Terricolous Lichens in India. New York: Springer, pp. 53-71.

Rikkinen J (2003) Ecological and evolutionary role of photobiont-mediated guilds in lichens. Symbiosis 34, 99-110. 
Rikkinen J (2013) Molecular studies on cyanobacterial diversity in lichen symbiosis. MycoKeys 6, 3-32.

Rikkinen J (2017) Symbiotic cyanobacteria in lichens. In Grube M, Seckbach J and Muggia L (eds), Algal and Cyanobacterial Symbioses. London: World Scientific Publishing Europe Ltd, pp. 147-167.

Rikkinen J, Oksanen I and Lohtander K (2002) Lichen guilds share related cyanobacterial symbionts. Science 297, 357.

Rindi F and Guiry MD (2002) Diversity, life history, and ecology of Trentepohlia and Printzina (Trentepohliales, Chlorophyta) in urban habitats in western Ireland. Journal of Phycology 38, 39-54.

Rindi F, Menéndez JL, Guiry MD and Rico JM (2004) The taxonomy and distribution of Phycopeltis (Trentepohliaceae, Chlorophyta) in Europe. Cryptogamie, Algologie 25, 3-17.

Rindi F, Lam DW and López-Bautista JM (2009) Phylogenetic relationships and species circumscription in Trentepohlia and Printzina (Trentepohliales, Chlorophyta). Molecular Phylogenetics and Evolution 52, 329-339.

Rindi F, Mikhailyuk TI, Sluiman HJ, Friedl T and López-Bautista JM (2011) Phylogenetic relationships in Interfilum and Klebsormidium (Klebsormidiophyceae, Streptophyta). Molecular Phylogenetics and Evolution 58, 218-231.

Rodgers GA and Stewart WDP (1977) The cyanophyte-hepatic symbiosis. New Phytologist 78, 441-458.

Rola K, Lenart-Borón A, Borón P and Osyczka P (2021) Heavy-metal pollution induces changes in the genetic composition and anatomical properties of photobionts in pioneer lichens colonizing post-industrial habitats. Science of the Total Environment 750, 141439.

Romeike J, Friedl T, Helm G and Ott S (2002) Genetic diversity of algal and fungal partners in four species of Umbilicaria (lichenized ascomycetes) along a transect of the Antarctic Peninsula. Molecular Biology and Evolution 19, 1209-1217.

Roskin PA (1970) Ultrastructure of the host-parasite interaction in the basidiolichen Cora pavonia (Web.) E. Fries. Archiv für Mikrobiologie 70, 176-182.

Ruprecht U, Brunauer G and Printzen C (2012) Genetic diversity of photobionts in Antarctic lecideoid lichens from an ecological viewpoint. Lichenologist 44, 661-678.

Ruprecht U, Brunauer G and Türk R (2014) High photobiont diversity in the common European soil crust lichen Psora decipiens. Biodiversity and Conservation 23, 1771-1785.

Ruprecht U, Fernández-Mendoza F, Türk R and Fryday AM (2020) High levels of endemism and local differentiation in the fungal and algal symbionts of saxicolous lecideoid lichens along a latitudinal gradient in southern South America. Lichenologist 52, 287-303.

Sadowska-Deś AD, Dal Grande F, Lumsch HT, Beck A, Otte J, Hur J-S, Kim JA and Schmitt I (2014) Integrating coalescent and phylogenetic approaches to delimit species in the lichen photobiont Trebouxia. Molecular Phylogenetics and Evolution 76, 202-210.

Sadowsky A and Ott S (2016) Symbiosis as a successful strategy in continental Antarctica: performance and protection of Trebouxia photosystem II in relation to lichen pigmentation. Polar Biology 39, 139-151.

Saini KC, Nayaka S and Bast F (2019) Diversity of lichen photobionts: their coevolution and bioprospecting potential. In Satyanarayana T, Johri BN and Das SK (eds), Microbial Diversity in Ecosystem Sustainability and Biotechnological Applications. Singapore: Springer Singapore, pp. 307-323.

Sanders WB (1994) Role of lichen rhizomorphs in thallus propagation and substrate colonization. Cryptogamic Botany 4, 283-289.

Sanders WB (2001) Composite thalli of Sticta sp. from Brazil with morphologically similar lobes containing either a chlorobiont or a cyanobiont layer. Symbiosis 31, 47-55.

Sanders WB (2002) In situ development of the foliicolous lichen Phyllophiale (Trichotheliaceae) from propagule germination to propagule production. American Journal of Botany 89, 1741-1746.

Sanders WB (2005) Observing microscopic phases of lichen life cycles on transparent substrata placed in situ. Lichenologist 37, 373-382.

Sanders WB (2014) Complete life cycle of the lichen fungus Calopadia puiggarii (Pilocarpaceae, Ascomycetes) documented in situ: propagule dispersal, establishment of symbiosis, thallus development, and formation of sexual and asexual reproductive structures. American Journal of Botany 101, $1836-1848$.
Sanders WB and de los Ríos A (2015) Structure and in situ development of the microlichen Gyalectidium paolae (Gomphillaceae, Ascomycota), an overlooked colonist on palm leaves in southwest Florida. American Journal of Botany 102, 1403-1412.

Sanders WB and Lücking R (2002) Reproductive strategies, relichenization and thallus development observed in situ in leaf-dwelling lichen communities. New Phytologist 155, 425-435.

Sanders WB and Rico VJ (1992) Lichenizing rhizomorphs and thallus development in the squamulose lichen Aspicilia crespiana Rico ined. (Lecanorales, Ascomycetes). Botanica Acta 105, 449-456.

Sanders WB, Wierzchos J and Ascaso C (1994) Physical interactions of two rhizomorph-forming lichens with their rock substrate. Acta Botanica 107, 432-439.

Sanders WB, Moe RL and Ascaso C (2004) The intertidal marine lichen formed by the pyrenomycete fungus Verrucaria tavaresiae and the brown alga Petroderma maculiforme (Phaeophyceae): thallus organization and symbiont interaction. American Journal of Botany 91, 511-522.

Sanders WB, Moe RL and Ascaso C (2005) Ultrastructural study of the brown alga Petroderma maculiforme (Phaeophyceae) in the free-living state and in lichen symbiosis with the intertidal marine fungus Verrucaria tavaresiae (Ascomycotina). European Journal of Phycology 40, 353-361.

Sanders WB, Pérez-Ortega S, Nelsen MP, Lücking R and de los Ríos A (2016) Heveochlorella (Trebouxiophyceae): a little-known genus of unicellular green algae outside the Trebouxiales emerges unexpectedly as a major clade of lichen photobionts in foliicolous communities. Journal of Phycology 52, 840-853.

Santesson R (1952) Foliicolous lichens I. A revision of the taxonomy of the obligately foliicolous, lichenized fungi. Symbolae Botanicae Upsaliensis 12, 1-590.

Schaper T and Ott S (2003) Photobiont selectivity and interspecific interactions in lichen communities. I. Culture experiments with the mycobiont Fulgensia bracteata. Plant Biology 5, 441-450.

Scheidegger C (1995) Reproductive strategies in Vezdaea (Lecanorales, lichenized Ascomycetes): a low-temperature scanning electron microscope study of a ruderal species. Cryptogamic Botany 5, 163-171.

Schmitt I and Lumbsch HT (2001) Identification of the photobionts in Trapeliopsis and Pertusaria using SSU ribosomal DNA sequences obtained from PCR amplification with a non-green-algal primer. Mycotaxon 78, 407-411.

Schüßler A (2012) The Geosiphon-Nostoc endosymbiosis and its role as a model for arbuscular mycorrhiza research. In Hock B (ed.), The Mycota IX. Fungal Associations, 2nd Edn. Berlin: Springer-Verlag, pp. 77-91.

Schuster G (1992) Development of adventive thalli in Umbilicaria Hoffm. Flora 187, 201-207.

Schuster G, Ott S and Jahns HM (1985) Artificial culture of lichens in the natural environment. Lichenologist 17, 147-153.

Schwendener S (1869) Die Algentypen der Flechtengonidien. Basel: Universitaetsbuchdruckerei von C. Schultze.

Scott GD (1957) Lichen terminology. Nature 179, 486-487.

Scott GD (1960) Studies of the lichen symbiosis I. The relationship between nutrition and moisture content in the maintenance of the symbiotic state. New Phytologist 59, 374-381.

Seto K, Matsuzawa T, Kuno H and Kagami M (2020) Morphology, ultrastructure, and molecular phylogeny of Aphelidium collabens sp. nov. (Aphelida), a parasitoid of a green alga Coccomyxa sp. Protist 171, 125728.

Silva PC (1979) Review of the taxonomic history and nomenclature of the yellow-green algae. Archiv für Protistenkunde 121, 20-63.

Simon A, Goffinet B, Magain N and Sérusiaux E (2018) High diversity, high insular endemism and recent origin in the lichen genus Sticta (lichenized Ascomycota, Peltigerales) in Madagascar and the Mascarenes. Molecular Phylogenetics and Evolution 122, 15-28.

Singh G, Dal Grande F, Divakar PK, Otte J, Crespo A and Schmitt I (2017) Fungal-algal association patterns in lichen symbiosis linked to macroclimate. New Phytologist 214, 317-329.

Škaloud P and Peksa O (2010) Evolutionary inferences based on ITS rDNA and actin sequences reveal extensive diversity of the common lichen alga Asterochloris (Trebouxiophyceae, Chlorophyta). Molecular Phylogenetics and Evolution 54, 36-46. 
Škaloud P, Neustupa J, Radochová B and Kubínová L (2005) Confocal microscopy of chloroplast morphology and ontogeny in three strains of Dictyochloropsis (Trebouxiophyceae, Chlorophyta). Phycologia 44, 261-269.

Škaloud P, Steinová J, Řidká T and Vančurová L (2015) Assembling the challenging puzzle of algal biodiversity: species delimitation within the genus Asterochloris (Trebouxiophyceae, Chlorophyta). Journal of Phycology 51, 507-527.

Škaloud P, Friedl T, Hallmann C, Beck A and Dal Grande F (2016) Taxonomic revision and species delimitation of coccoid green algae currently assigned to the genus Dictyochloropsis (Trebouxiophyceae, Chlorophyta). Journal of Phycology 52, 599-617.

Škaloud P, Moya P, Molins A, Peksa O, Santos-Guerra A and Barreno E (2018) Untangling the hidden intrathalline microalgal diversity in Parmotrema pseudotinctorum: Trebouxia crespoana sp. nov. Lichenologist 50, 357-369.

Skuja H (1943) Ein Fall von fakultativer Symbiose zwischen operculatem Discomycet und einer Chlmydomonade. Archiv für Protistenkunde 96, 365-376.

Slocum RD (1980) Light and electron microscopic investigations in the Dictyonemataceae (basidiolichens) II. Dictyonema irpicinum. Canadian Journal of Botany 58, 1005-1015.

Slocum RD, Ahmadjian V and Hildreth KC (1980) Zoosporogenesis in Trebouxia gelatinosa: ultrastructure potential for zoospore release and implications for the lichen association. Lichenologist 12, 173-187.

Smith DC (1974) Transport from symbiotic algae and symbiotic chloroplasts to host cells. Symposia of the Society for Experimental Biology 28, 485-520.

Smith DC (2019) What can lichens tell us about 'real fungi'? Symbiosis 77, 93-98.

Smith DC and Drew EA (1965) Studies in the physiology of lichens. V. Translocation from the algal layer to the medulla in Peltigera polydactyla. New Phytologist 64, 195-200.

Smith EC and Griffiths H (1996) The occurrence of the chloroplast pyrenoid is correlated with the activity of a $\mathrm{CO}_{2}$-concentrating mechanism and carbon isotope discrimination in lichens and bryophytes. Planta 198, 6-16.

Smith H, Dal Grande F, Muggia L, Keuler R, Divakar PK, Grewe F, Schmitt I, Lumbsch HT and Leavitt SD (2020) Metagenomic data reveal diverse fungal and algal communities associated with the lichen symbiosis. Symbiosis 82, 133-147.

Solhaug KA and Gauslaa Y (1996) Parietin, a photoprotective secondary product of the lichen Xanthoria parietina. Oecologia 108, 412-418.

Solovchenko AE (2013) Physiology and adaptive significance of secondary carotenogenesis in green microalgae. Russian Journal of Plant Physiology 60, 1-13.

Spribille T, Tønsberg T, Stabentheiner E and Muggia L (2014) Reassessing evolutionary relationships in the filamentous cyanolichen genus Spilonema (Peltigerales, Lecanoromycetes). Lichenologist 46, 373-388.

Spribille T, Tuovinen V, Resl P, Vanderpool D, Wolinski H, Aime MC, Schneider K, Stabentheiner E, Toome-Heller M, Thor G, et al. (2016) Basidiomycete yeasts in the cortex of ascomycete macrolichens. Science 353, 488-492.

Stahl E (1877) Beiträge zur Entwicklungsgeschichte der Flechten. II. Ueber die Bedeutung der Hymenialgonidien. Leipzig: Arthur Felix.

Steinová J, Škaloud P, Yahr R, Bestová H and Muggia L (2019) Reproductive and dispersal strategies shape the diversity of mycobiont-photobiont association in Cladonia lichens. Molecular Phylogenetics and Evolution 134, 226-237.

Stenroos S, Stocker-Wörgötter E, Yoshimura I, Myllys L, Thell A and Hyvönen J (2003) Culture experiments and DNA sequence data confirm the identity of Lobaria photomorphs. Canadian Journal of Botany 81, 232-247.

Stenroos S, Högnabba F, Myllys L, Hyvönen J and Thell A (2006) High selectivity in symbiotic associations of lichenized ascomycetes and cyanobacteria. Cladistics 22, 230-238.

Stevenson RN and South GR (1974) Coccomyxa parasitica sp. nov. (Coccomyxaceae, Chlorococcales), a parasite of giant scallops in Newfoundland. British Phycological Journal 9, 319-329.

Stocker-Wörgötter E (2001) Experimental lichenology and microbiology of lichens: culture experiments, secondary chemistry of cultured mycobionts, resynthesis, and thallus morphogenesis. Bryologist 104, 576-581.

Stocker-Wörgötter E and Hager A (2008) Culture methods for lichens and lichen symbionts. In Nash, TH III (ed.), Lichen Biology. New York: Cambridge University Press, pp. 353-363.
Summerer M, Sonntag B and Sommaruga R (2008) Ciliate-symbiont specificity of freshwater endosymbiotic Chlorella (Trebouxiophyceae, Chlorophyta). Journal of Phycology 44, 77-84.

Summerfield TC and Eaton-Rye JJ (2006) Pseudocyphellaria crocata, P. neglecta and $P$. perpetua from the Northern and Southern Hemispheres are a phylogenetic species and share cyanobionts. New Phytologist 170, 597-607.

Suto Y and Ohtani S (2009) Morphology and taxonomy of five Cephaleuros species (Trentepohliaceae, Chlorophyta) from Japan, including three new species. Phycologia 48, 213-236.

Suto Y and Ohtani S (2013) Seasonal development of five Cephaleuros species (Trentepohliaceae, Chlorophyta) on the leaves of woody plants and the behaviors of their gametes and zoospores. Phycological Research 61, 105-115.

Svenning MM, Eriksson T and Rasmussen U (2005) Phylogeny of symbiotic cyanobacteria within the genus Nostoc based on $16 \mathrm{~S}$ rDNA sequence analyses. Archives of Microbiology 183, 19-26.

Syasina IG, Kukhlevsky AD, Kovaleva AL and Vaschenko MA (2012) Phylogenetic and morphological characterization of the green alga infesting the horse mussel Modiolus from Vityaz Bay (Peter the Great Bay, Sea of Japan). Journal of Invertebrate Pathology 111, 175-181.

Takeshita S (2001) A taxonomic revision of the genus Trebouxia. Hikobia 13, $425-455$.

Takeshita S, Nakano T and Iwatsuki Z (1989) Phycobionts of some Japanese species of Pertusaria (Pertusariaceae). Plant Systematics and Evolution 165, 49-54.

Takeshita S, Tokizawa M, Handa S and Okamoto T (2010) A report of the photobiont isolated from Multiclavula clara (Berk. \& Curt.) R. H. Peterson (Clavariaceae, lichenized Basidiomycetes). Hikobia 15, 493-497. [In Japanese with English abstract and figure legends]

Thomas EA (1939) Über die Biologie von Flechtenbildnern. Beiträge zur Kryptogamenflora der Schweiz 9, 1-208 (+ 6 tab.).

Thompson RH and Wujek DE (1992) Printzina gen. nov. (Trentepohliaceae), including a description of a new species. Journal of Phycology 28, 232-237.

Thompson RH and Wujek DE (1997) Trentepohliales: Cephaleuros, Phycopeltis and Stomatochroon. Morphology Taxonomy and Ecology. Enfield, New Hampshire: Science Publishers.

Thüs H, Muggia L, Pérez-Ortega S, Favero-Longo SE, Joneson S, O'Brien H, Nelsen MP, Duque-Thüs R, Grube M, Friedl T, et al. (2011) Revisiting photobiont diversity in the lichen family Verrucariaceae (Ascomycota). European Journal of Phycology 46, 399-415.

Tibell L (2001) Photobiont association and molecular phylogeny of the lichen genus Chaenotheca. Bryologist 104, 191-198.

Tibell L and Beck A (2002) Morphological variation, photobiont association and ITS phylogeny of Chaenotheca phaeocephala and C. subroscida (Coniocybaceae, lichenized ascomycetes). Nordic Journal of Botany 21, 651-660.

Tønsberg T and Goward T (2001) Sticta oroborealis sp. nov., and other Pacific North American lichens forming dendriscocauloid cyanotypes. Bryologist 104, 12-23.

Tønsberg T and Holtan-Hartwig J (1983) Phycotype pairs in Nephroma, Peltigera and Lobaria in Norway. Nordic Journal of Botany 3, 681-688.

Trembley ML, Ringli C and Honegger R (2002a) Differential expression of hydrophobins $D G H 1, D G H 2$ and $D G H 3$ and immunolocalization of DGH1 in strata of the lichenized basidiocarp of Dictyonema glabratum. New Phytologist 154, 185-195.

Trembley ML, Ringli C and Honegger R (2002b) Morphological and molecular analysis of early stages in the resynthesis of the lichen Baeomyces rufus. Mycological Research 106, 768-776.

Trémouillaux-Guiller J and Huss VAR (2007) A cryptic intracellular green alga in Ginkgo biloba: ribosomal DNA markers reveal worldwide distribution. Planta 226, 553-557.

Trémouillaux-Guiller J, Rohr T, Rohr R and Huss VAR (2002) Discovery of an endophytic alga in Ginkgo biloba. American Journal of Botany 89, 727-733.

Tschaikner A, Ingolić E, Holzinger A and Gärtner G (2007) Phycobionts of some species of Evernia and Ramalina. Herzogia 20, 53-60.

Tschermak E (1941a) Untersuchungen über die Beziehung von Pilz und Alge im Flechtenthallus. Österreichische Botanische Zeitschrift 90, 233-307. 
Tschermak L (1941b) Beitrag zur Entwicklungsgeschichte und Morphologie der Protococcale Trochiscia granulata. Österreichische Botanische Zeitschrift 90, 67-73.

Tschermak-Woess E (1953) Über wenig bekannte und neue Flechtengonidien III. Die Entwicklungsgeschichte von Leptosira thrombii nov. spec., der Gonidie von Thrombium epigaeum. Österreichische Botanische Zeitschrift 100, 203-216.

Tschermak-Woess E (1970) Über wenig bekannte und neue Flechtengonidien V. Der Phycobiont von Verrucaria aquatilis und die Fortpflanzung von Pseudopleurococcus arthopyreniae. Österreichische Botanische Zeitschrift 118, 443-455.

Tschermak-Woess E (1976) Algal taxonomy and the taxonomy of lichens: the phycobiont of Verrucaria adriatica. In Brown DH, Hawksworth DL and Bailey RL (eds), Lichenology: Progress and Problems. London: Academic Press, pp. 79-88.

Tschermak-Woess E (1978) Myrmecia reticulata as a phycobiont and freeliving - free-living Trebouxia - the problem of Stenocybe septata. Lichenologist 10, 69-79.

Tschermak-Woess E (1980a) Asterochloris phycobiontica, gen. et spec. nov., der Phycobiont der Flechte Varicellaria carneonivea. Plant Systematics and Evolution 135, 279-294.

Tschermak-Woess E (1980b) Elliptochloris bilobata, gen. et spec. nov., der Phycobiont von Catolechia wahlenbergii. Plant Systematics and Evolution 136, 63-72.

Tschermak-Woess E (1981) Zur Kenntnis der Phycobionten von Lobaria linita und Normandina pulchella. Nova Hedwigia 35, 63-73.

Tschermak-Woess E (1983) Das Haustorialsystem von Dictyonema kennzeichend für die Gattung. Plant Systematics and Evolution 143, 109-115.

Tschermak-Woess E (1985) Elliptochloris bilobata kein ganz seltener Photobiont. Herzogia 7, 105-116.

Tschermak-Woess E (1988a) The algal partner. In Galun M (ed.), CRC Handbook of Lichenology. Boca Raton, Florida: CRC Press, pp. 39-92.

Tschermak-Woess E (1988b) New and known taxa of Chlorella (Chlorophyceae): occurrence as lichen phycobionts and observations on living dictyosomes. Plant Systematics and Evolution 159, 123-139.

Tschermak-Woess E (1989) Developmental studies in trebouxioid algae and taxonomical consequences. Plant Systematics and Evolution 164, 161-195.

Tschermak-Woess E (1995) Dictyochloropsis splendida (Chlorophyta), the correct phycobiont of Phlyctis argena and the high degree of selectivity involved. Lichenologist 27, 169-187.

Tschermak-Woess E and Poelt J (1976) Vezdaea, a peculiar lichen genus, and its phycobiont. In Brown DH, Hawksworth DL and Bailey RL (eds), Lichenology: Progress and Problems. London: Academic Press, pp. 89-105.

Tschermak-Woess E, Bartlett J and Peveling E (1983) Lichenothrix riddlei is an ascolichen and also occurs in New Zealand - light and electron microscopical investigation. Plant Systematics and Evolution 143, 293-309.

Tzovaras BG, Segers FHID, Bicker A, Dal Grande F, Otte J, Anvar SY, Hankeln T, Schmitt I and Ebersberger I (2020) What is in Umbilicaria pustulata? A metagenomic approach to reconstruct the holo-genome of a lichen. Genome Biology and Evolution 12, 309-324.

Uher B (2008) Spatial distribution of cyanobacteria and algae from the tombstone in a historic cemetery in Bratislava, Slovakia. Fottea 9, 81-92.

van den Hoek C, Mann DG and Jahns HM (1995) Algae: An Introduction to Phycology. Cambridge: Cambridge University Press.

Vančurová L (2012) Diverzita fotobiontů ve stélkách lišejníků rodu Stereocaulon [Photobiont diversity in the lichen genus Stereocaulon (Lecanoromycetes, Ascomycota)]. Master's thesis, Charles University, Prague. [In Czech, with English summary].

Vančurová L, Peksa O, Němcová $\mathbf{Y}$ and Škaloud P (2015) Vulcanochloris (Trebouxiales, Trebouxiophyceae), a new genus of lichen photobiont from La Palma, Canary Islands, Spain. Phytotaxa 219, 118-132.

Vančurová L, Muggia L, Peksa O, Rídká T and Škaloud P (2018) The complexity of symbiotic interactions influences the ecological amplitude of the host: a case study in Stereocaulon (lichenized Ascomycota). Molecular Ecology 27, 3016-3033.
Vargas Castillo R and Beck A (2012) Photobiont selectivity and specificity in Caloplaca species in a fog-induced community in the Atacama Desert, northern Chile. Fungal Biology 116, 665-676.

Villanueva CD, Hašler P, Dvořák P, Poulíčková A and Casamatta DA (2018) Brasilonema lichenoides sp. nov. and Chroococcidiopsis lichenoides sp. nov. (Cyanobacteria): two novel cyanobacterial constituents isolated from a tripartite lichen of headstones. Journal of Phycology 54, 224-233.

Vischer W (1960) Reproduktion und systematische Stellung einiger Rindenund Bodenalgen. Schweizerische Zeitschrift für Hydrologie 22, 330-349.

Võ GTP (2016) Cyanobacterial lichenized fungi and their photobionts in Vietnam. Ph.D. thesis, Technische Universität Kaiserslautern.

Voytsekhovich A and Beck A (2016) Lichen photobionts of the rocky outcrops of Karadag massif (Crimean Peninsula). Symbiosis 68, 9-24.

Voytsekhovich A, Dymytrova L and Nadyeina O (2011) Photobiont composition of some taxa of the genera Micarea and Placynthiella (Lecanoromycetes, lichenized Ascomycota) from Ukraine. Folia Cryptogamica Estonica 48, 135-148.

Wagner J and Létrouit-Galinou M-A (1988) Structure et ontogenèse du thalle squamuleux du lichen Endocarpon pusillum. Canadian Journal of Botany 66, 2118-2127.

Wagner M, Bathke AC, Cary CS, Green TGA, Junker RR, Trutschnig W and Ruprecht U (2020) Myco- and photobiont associations in crustose lichens in the McMurdo Dry Valleys (Antarctica) reveal high differentiation along an elevational gradient. Polar Biology 43, 1967-1983.

Ward HM (1884) On the structure, development and life history of a tropical epiphyllous lichen (Strigula complanata Fée, fide Rev. J. M. Crombie). Transactions of the Linnean Society of London 2, 87-119.

Warén H (1920) Reinkultur von Flechtengonidien. Finska VetenskapsSocietetens Förhandlingar 61, 1-79.

Watanabe S, Nakano T and Deguchi H (1997) Photobionts isolated from maritime lichens. Journal of Marine Biotechnology 5, 103-112.

Waterbury JB and Stanier RY (1978) Pattern of growth and development in pleurocapsalean cyanobacteria. Microbiological Reviews 42, 2-44.

Wedin M, Maier S, Fernández-Brime S, Cronholm B, Westberg $M$ and Grube M (2016) Microbiome change by symbiotic invasion in lichens. Environmental Microbiology 18, 1428-1439.

Werner R-G (1931) Histoire de la synthèse liquénique. Mémoires de la Société des Science Naturelles du Maroc 27, 7-45.

Werth S (2010) Biogeography and phylogeography of lichen fungi and their photobionts. In Fontaneto D (ed.), Biogeography of Microscopic Organisms: Is Everything Small Everywhere? Cambridge: Cambridge University Press, pp. 191-208.

Werth S and Scheidegger C (2012) Congruent genetic structure in the lichenforming fungus Lobaria pulmonaria and its green-algal photobiont. Molecular Plant-Microbe Interactions 25, 220-230.

Werth S and Sork VL (2014) Ecological specialization in Trebouxia (Trebouxiophyceae) photobionts of Ramalina menziesii (Ramalinaceae) across six range-covering ecoregions of western North America. American Journal of Botany 101, 1127-1140.

Wetmore C (1970) The lichen family Heppiaceae in North America. Annals of the Missouri Botanical Gardens 57, 158-209.

Williams L, Colesie C, Ullmann A, Westberg M, Wedin M and Büdel B (2017) Lichen acclimation to changing environments: photobiont switching vs. climate-specific uniqueness in Psora decipiens. Ecology and Evolution 7, 2560-2574

Wirtz N, Lumbsch HT, Green TGA, Türk R, Pintado A, Sancho LG and Schroeter B (2003) Lichen fungi have low cyanobiont selectivity in maritime Antarctica. New Phytologist 160, 177-183.

Withrow K and Ahmadjian V (1983) The ultrastructure of Chiodecton sanguineum. Mycologia 75, 337-339.

Wolf M, Hepperle D and Krienitz L (2003) On the phylogeny of Radiococcus, Planktosphaeria and Schizochlamydella (Radiococcaceae, Chlorophyta). Biologia, Bratislava 58, 759-765.

Wolk CP, Ernst A and Elhai J (1994) Heterocyst metabolism and development. In Bryant DA (ed.), The Molecular Biology of Cyanobacteria. Dordrecht: Kluwer Academic Publishers, pp. 769-823.

Wornik S and Grube M (2010) Joint dispersal does not imply maintenance of partnerships in lichen symbioses. Microbial Ecology 59, 150-157. 
Wynne MJ (1969) Life history and systematic studies of some Pacific North American Phaeophyceae (brown algae). University of California Publications in Botany 50, 1-88.

Xu H, Deckert RJ and Garbary DJ (2008) Ascophyllum and its symbionts. X. Ultrastructure of the interaction between A. nodosum (Phaeophyceae) and Mycophycias ascophylli (Ascomycetes). Botany 86, 185-193.

Xu M, De Boer H, Olafssdottir ES, Omarsdottir S and Heiđmarsson S (2020) Phylogenetic diversity of the lichenized algal genus Trebouxia (Trebouxiophyceae, Chlorophyta): a new lineage and novel insights from fungal-algal association patterns of Icelandic cetrarioid lichens (Parmeliaceae, Ascomycota). Botanical Journal of the Linnean Society 194, 460-468.

Yahr R, Vilgalys R and DePriest PT (2004) Strong fungal specificity and selectivity for algal symbionts in Florida scrub Cladonia lichens. Molecular Ecology 13, 3367-3378.

Yahr R, Vilgalys R and DePriest PT (2006) Geographic variation in algal partners of Cladonia tenuis (Cladoniaceae) highlights the dynamic nature of a lichen symbiosis. New Phytologist 171, 847-860.

Yahr R, Florence A, Škaloud P and Voytsekhovich A (2015) Molecular and morphological diversity in photobionts associated with Micarea s. str. (Lecanorales, Ascomycota). Lichenologist 47, 403-414.

Yung CCM, Chan Y, Lacap DC, Pérez-Ortega S, de los Ríos A, Lee CK, Cary SC and Pointing S (2014) Characterization of chasmoendolithic community in Miers Valley, McMurdo Dry Valleys, Antarctica. Microbial Ecology 68, 351-359.

Zahlbruckner A (1907) Specieller Teil: Ascolichenes (Schlauchflechten); Hymenolichenes (Basidiomycetenflechten). In Engler A and Prantl K (eds), Die Naturlichen Pflanzenfamilien. I. Teil, 1. Abteilung*. Leipzig: Wilhelm Engelmann, pp. 49-243.
Zahradníková M, Andersen HL, Tønsberg T and Beck A (2017) Molecular evidence of Apatococcus, including A. fuscideae sp. nov., as photobiont in the genus Fuscidea. Protist 168, 425-438.

Zeitler I (1954) Untersuchungen über die Morphologie, Entwicklungsgeschichte und Systematik von Flechtengonidien. Österreichische Botanische Zeitschrift 101, 453-487.

Zhang J, Huss VAR, Sun X, Chang K and Pang D (2008) Morphology and phylogenetic position of a trebouxiophycean green alga (Chlorophyta) growing on the rubber tree, Hevea brasiliensis, with the description of a new genus and species. European Journal of Phycology, 43, 185-193.

Zhaxybayeva O, Gogrten JP, Charlebois RL, Doolittle WF and Papke RT (2006) Phylogenetic analyses of cyanobacterial genomes: quantification of horizontal gene transfer events. Genome Research 16, 1099-1108.

Zhu H, Zhao Z, Xia S, Hu Z and Liu G (2015) Morphological examination and phylogenetic analyses of Phycopeltis spp. (Trentepohliales, Ulvophyceae) from tropical China. PLoS ONE 10, e0114936.

Zhu H, Hu Z and Liu G (2017) Morphology and molecular phylogeny of Trentepohliales (Chlorophyta) from China. European Journal of Phycology 52, 330-341.

Zhu H, Li S, Hu Z and Liu G (2018) Molecular characterization of eukaryotic algal communities in the tropical phyllosphere based on real-time sequencing of the $18 \mathrm{~S}$ rDNA gene. BMC Plant Biology 18, 365.

Zoller S and Lutzoni F (2003) Slow algae, fast fungi: exceptionally high nucleotide substitution rate differences between lichenized fungi Omphalina and their symbiotic green algae Coccomyxa. Molecular Phylogenetics and Evolution 29, 629-640. 